San Jose State University

SJSU ScholarWorks

Spring 2013

\title{
There's No Place like Home? Telecommuting as a Viable Commuting Alternative for San Jose Government and Companies to Reduce Vehicle Miles Traveled and Greenhouse Gas Emissions
}

Jennifer Marie Piozet

San Jose State University

Follow this and additional works at: https://scholarworks.sjsu.edu/etd_projects

Part of the Urban Studies and Planning Commons

\section{Recommended Citation}

Piozet, Jennifer Marie, "There's No Place like Home? Telecommuting as a Viable Commuting Alternative for San Jose Government and Companies to Reduce Vehicle Miles Traveled and Greenhouse Gas Emissions" (2013). Master's Projects. 291. DOI: https://doi.org/10.31979/etd.6e4t-7fkv https://scholarworks.sjsu.edu/etd_projects/291

This Master's Project is brought to you for free and open access by the Master's Theses and Graduate Research at SJSU ScholarWorks. It has been accepted for inclusion in Master's Projects by an authorized administrator of SJSU ScholarWorks. For more information, please contact scholarworks@sjsu.edu. 


\section{There's No Place lke Home?}

Telecommuting as a Viable Commuting Alternative for San Jose Government and Companies to Reduce Vehicle Miles Traveled and Greenhouse Gas Emissions

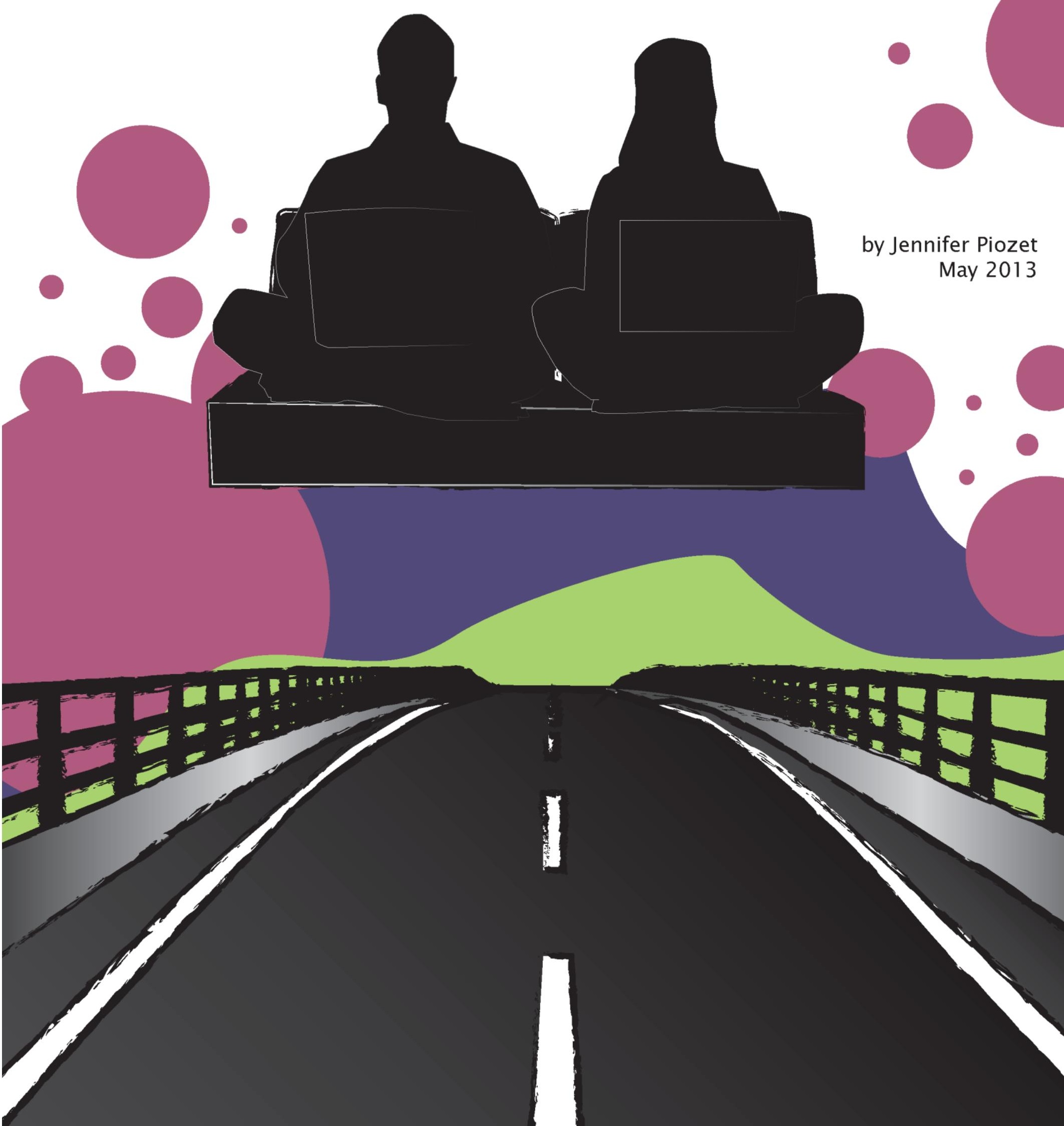


This page intentionally left blank. 


\title{
There's No Place like Home?
}

Telecommuting as a Viable Commuting Alternative for San Jose Government and Companies to Reduce Vehicle Miles Traveled and Greenhouse Gas Emissions

\author{
A Planning Report \\ Presented to \\ The Faculty of the Department of \\ Urban and Regional Planning \\ San José State University \\ In Partial Fulfillment \\ Of the Requirements for the Degree \\ Master of Urban Planning
}

By

Jennifer Marie Piozet

May 2013 
This page intentionally left blank. 


\section{Acknowledgements}

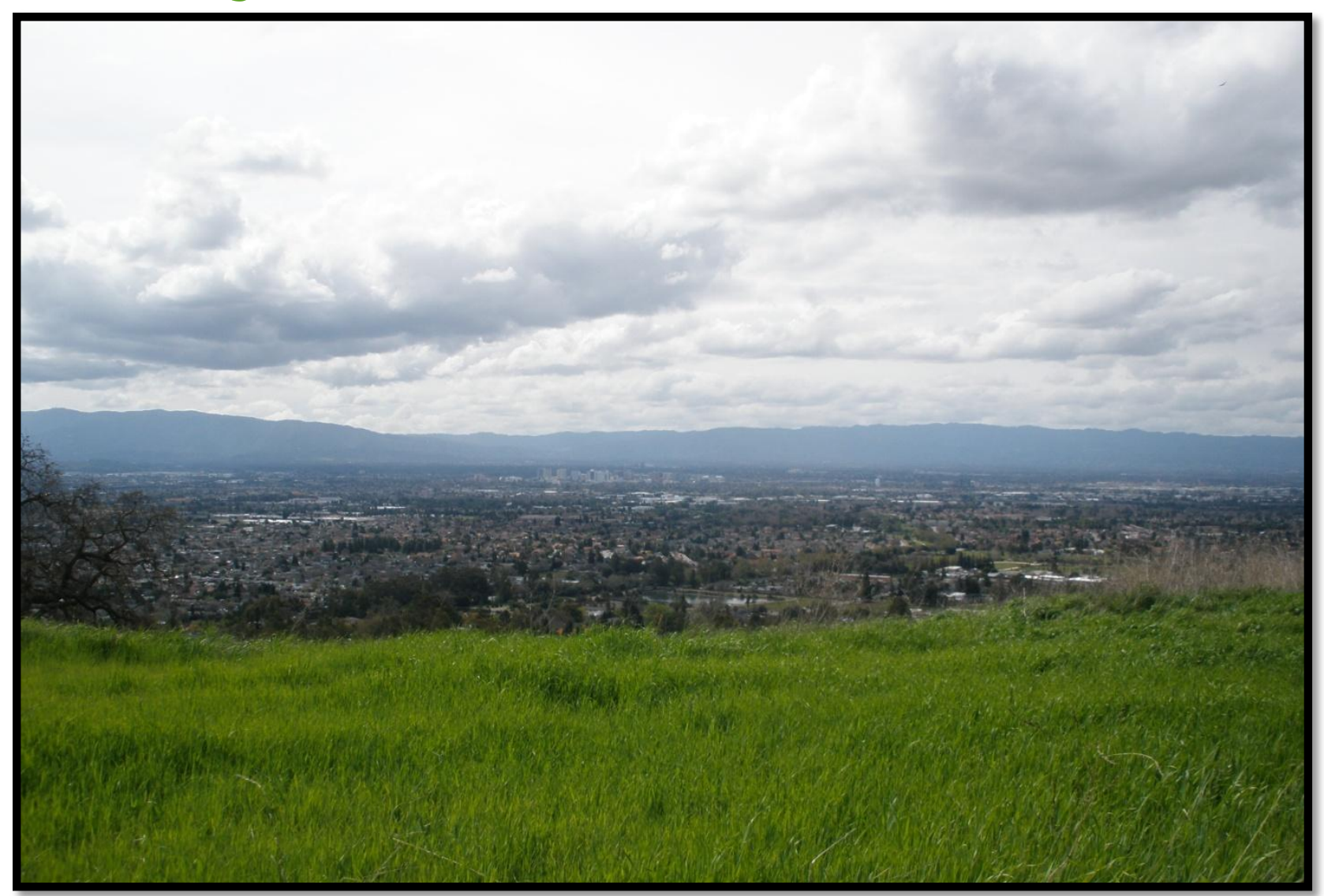

Figure 1: View of San Jose from the East Foothills (Piozet 2013)

Words will never be enough to express my gratitude to all who helped me through this process. This endeavor was not always easy, but it was worth it. I am humbled to be in a position where I can create a new slice of knowledge that may perhaps improve the understanding of telecommuting, its benefits, limitations, and possibilities.

To my husband Steven Piozet, for his love and understanding.

To my family, for giving me life and support.

To my advisors Rick Kos and Hilary Nixon, for their guidance.

To Sara Sichley, for being my 298 buddy.

To Brent Carvalho, for all his advice.

To all the interviewees, for their invaluable feedback.

To you, for reading this and maybe becoming a believer too. Let's start a commuting revolution! 
This page intentionally left blank. 


\section{Table of Contents}

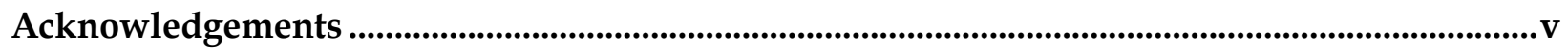

Table of Figures.....................................................................................................................................................ix

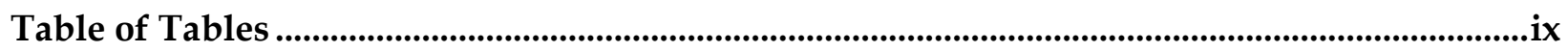

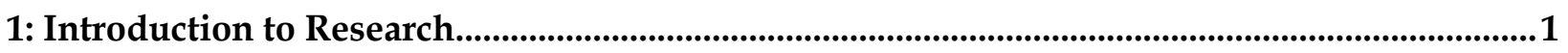

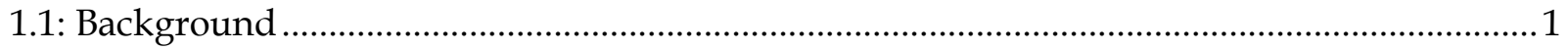

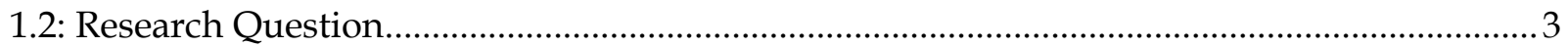

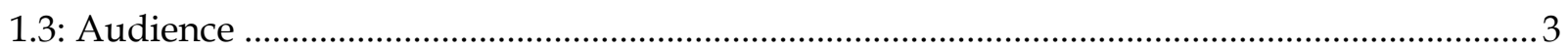

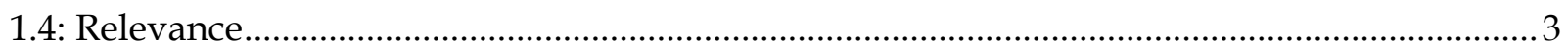

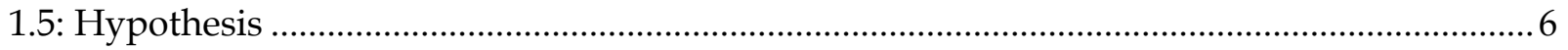

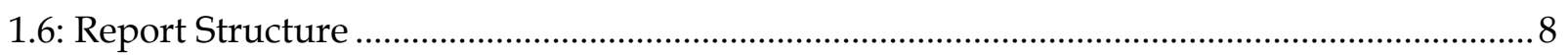

2: Setting the Stage: Telecommuting Policies and Programs and Their Impact on VMTs and

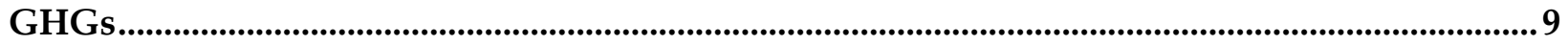

2.1: United States Federal Telecommuting Policies.............................................................. 9

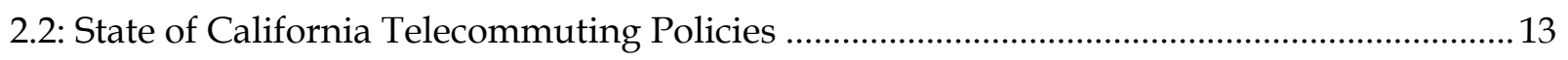

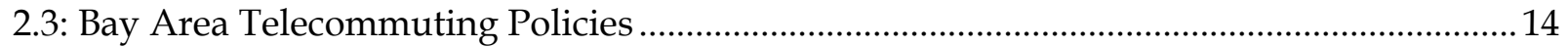

2.4: Santa Clara County Telecommuting Policies ...................................................................... 15

2.5: Overview of Telecommuting Polices at the City Level ..................................................... 15

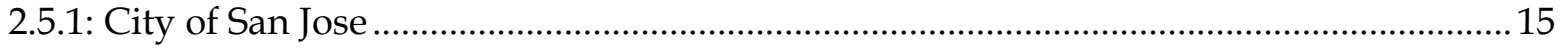

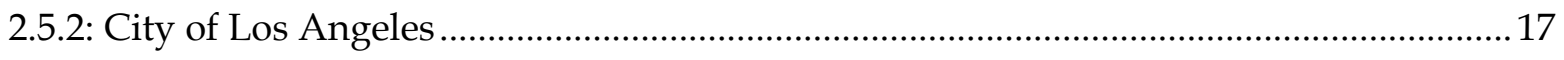

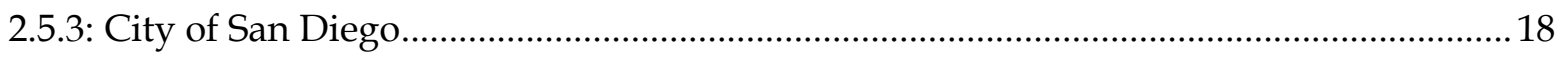

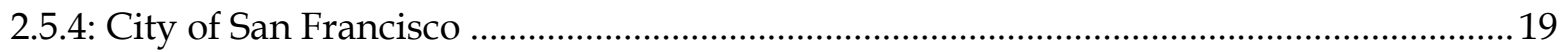

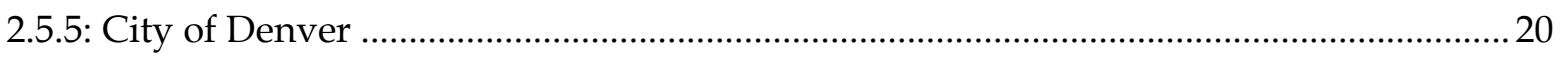

3: The Findings from the Literature and Interviews .......................................................................... 23

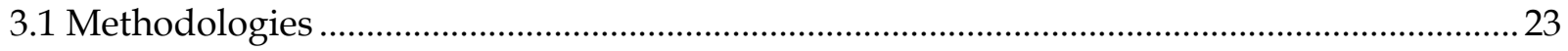

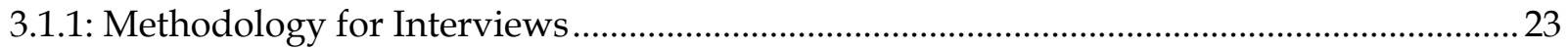

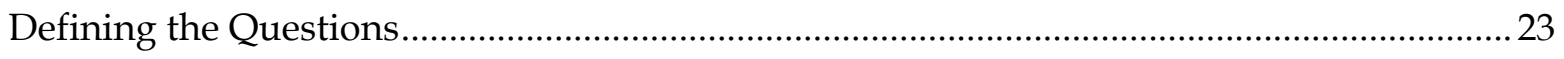

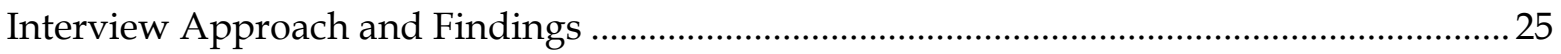

3.2: Methodology for Interview and Literature Analysis and Synthesis ................................. 25

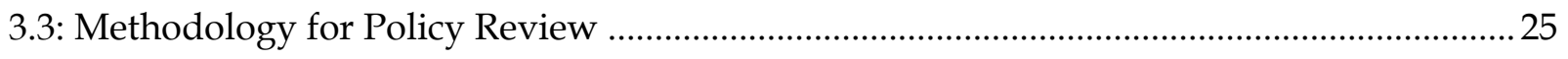

3.4: Themes Present in Both the Literature and Interviews ..................................................... 26

3.4.1 Telecommuting's Effect on Land Use ........................................................................ 26 
3.4.2: Effective Telecommuting Policies and Programs ......................................................... 28

3.4.3: Telecommuting's Role in Reducing VMTs and GHGs ............................................... 33

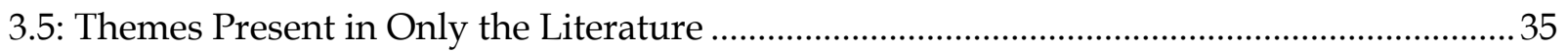

3.5.1: Effective Telecommuting Policies and Programs .......................................................... 35

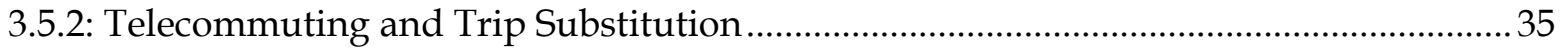

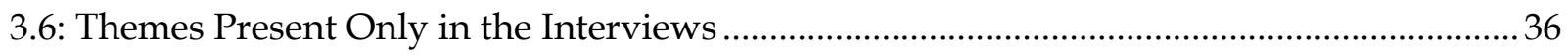

4: Synthesis, Discussion, and Recommendations for Telecommuting Adoption and Success 41

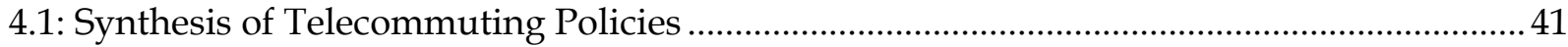

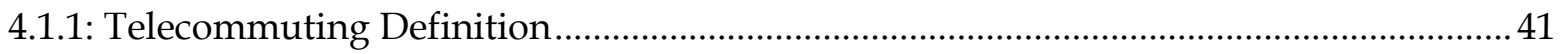

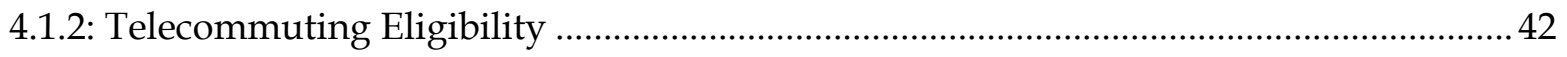

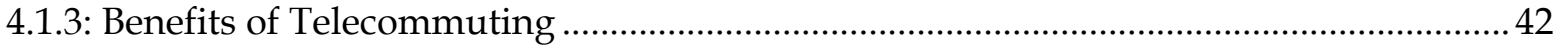

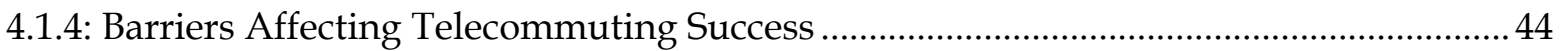

4.2: Discussion of Findings from Literature, Interviews and Policies ...................................... 44

4.2.1: Common Findings from Literature, Interviews and Policies ....................................... 44

4.2.2: Different and Innovative Findings from Literature, Interviews and Policies .............. 45

4.3: Recommendations for Telecommuting Adoption and Success......................................... 46

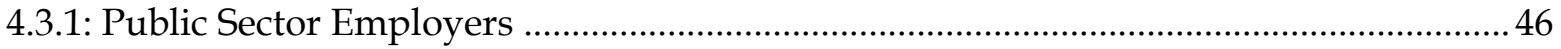

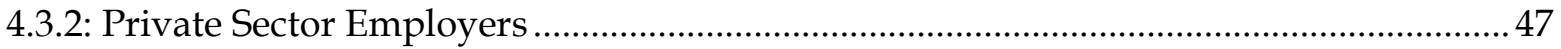

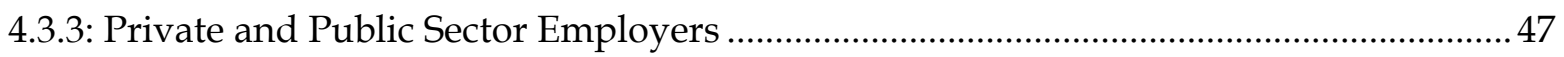

4.3.4: Opportunities for Further Research ….......................................................................... 47

Reference List ............................................................................................................................................51

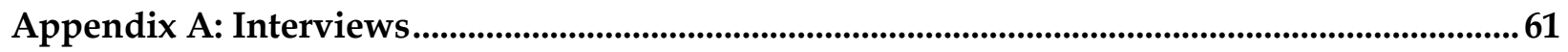

Appendix B: Synthesis of Telecommuting Policies .......................................................................... 79

Appendix C: Synthesis of Other Relevant Telecommuting Research ...........................................91 


\section{Table of Figures}

Figure 1: View of San Jose from the East Foothills..........................................................................

Figure 2: San Jose State University Tower Hall .....................................................................

Figure 3: Bay Area Leads "Mega-commuter" List ........................................................................... 5

Figure 4: An Ocean of Cars at a San Jose High-tech Company …................................................... 7

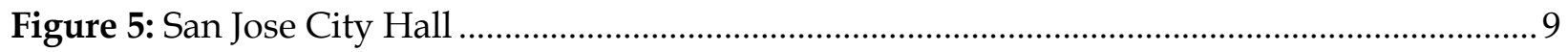

Figure 6: Traffic Congestion at Highway 17 Entrance in San Jose.............................................. 18

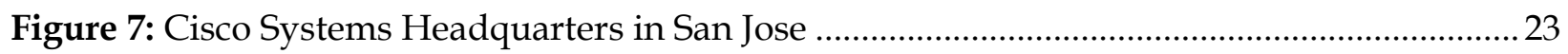

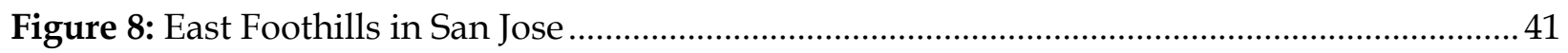

Figure 9: National Institutes of Health's Teleworking Cost and Environmental Saving Estimate

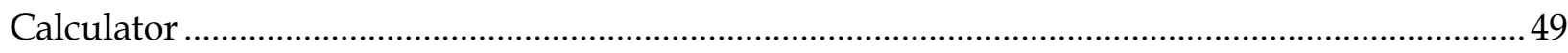

\section{Table of Tables}

Table 1: Jobs with Telecommuting Potential (Part- or Full-Time) ............................................... 11

Table 2: Population and Telecommuter Background Data ....................................................... 16

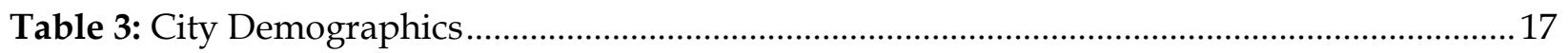

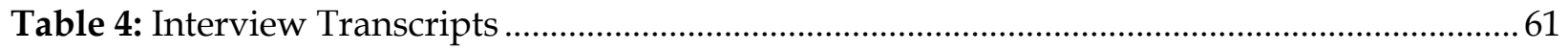

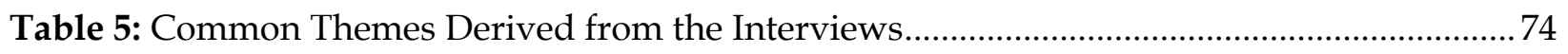

Table 6: Telecommuting Policy Definitions ................................................................................. 79

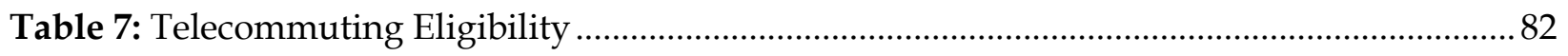

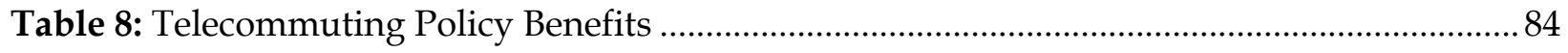

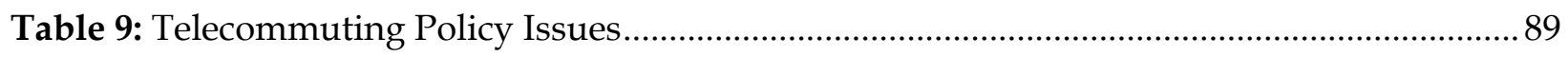

Table 10: Non-Policy Telecommuting Definition and Eligibility Criteria .................................... 91

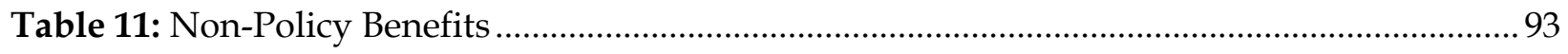

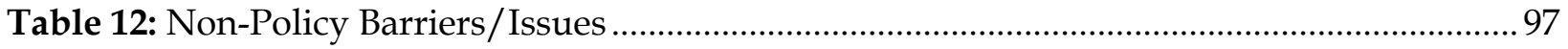

Note: All images in this report were taken or created by the author, Jennifer Piozet, unless otherwise noted. The images at the start of each chapter depict San Jose landmarks and assets. 
This page intentionally left blank. 


\section{1: Introduction to Research}

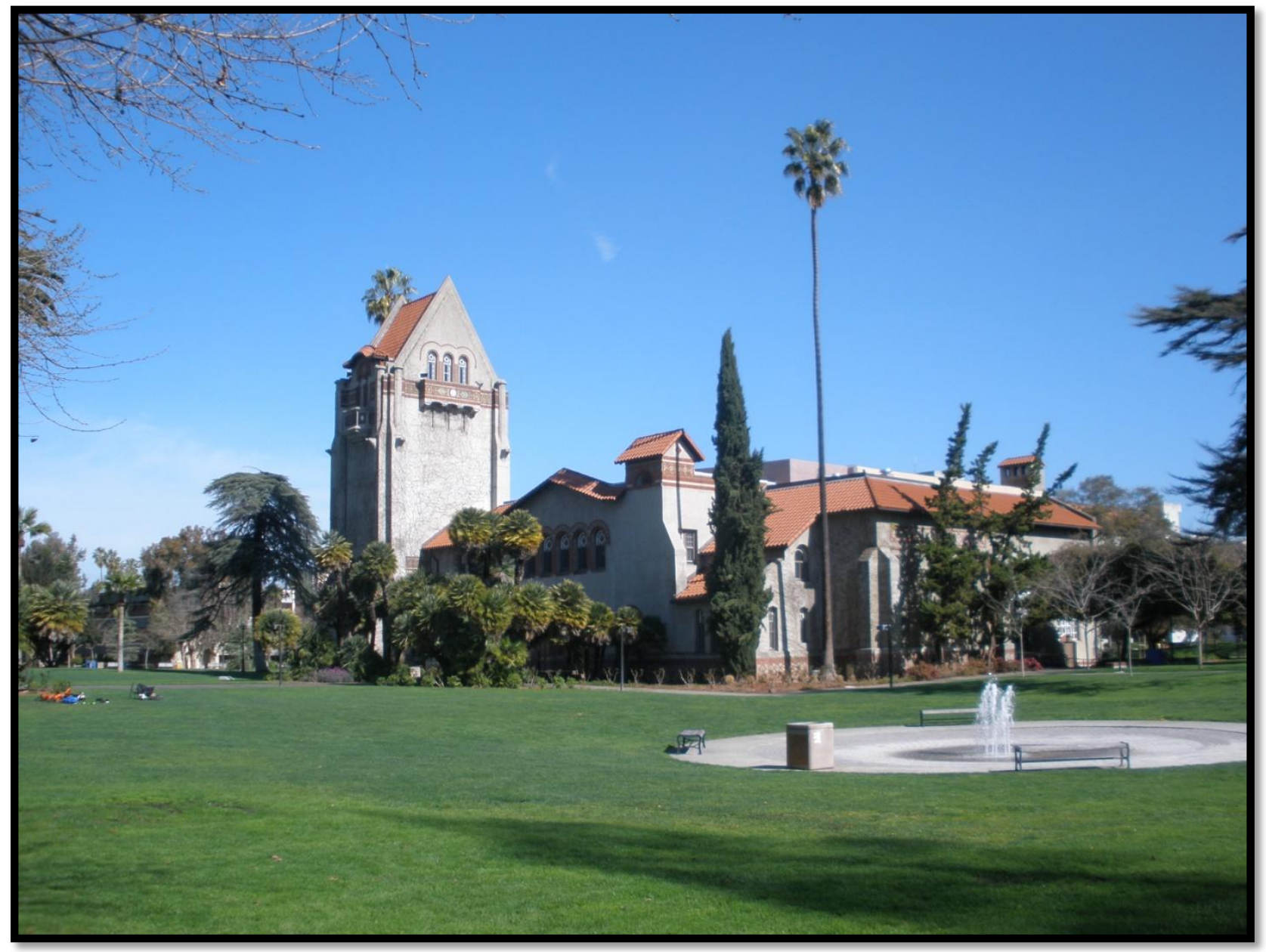

Figure 2: San Jose State University Tower Hall

\section{1: Background}

The term "telecommuting," also referred to as teleworking, tele-cottaging, and home-working, was first introduced by J.M. Nilles in 1975 (Bailey and Kurland 2002, 383 \& Bryant 2008, 135). It is defined as "working outside the conventional workplace" while using computer or telecommunications technologies (Bailey and Kurland 2002, 384). Telecommuting became popular in the 1970s when the oil crisis made commuting more stressful and costly due to increased gas prices and traffic congestion (Bailey and Kurland 2002, 387). Today, gas prices continue to rise, reinforcing the importance of commuting alternatives like telecommuting.

Telecommuting allows workers to escape workspace pressures, avoid long, stressful commutes or shift their commute times to non-peak traffic hours through the use of Information and Communications Technologies (ICTs) (Hill et al. 2012, 357; Bailey and Kurland 2002, 384). Workplace schedule flexibility even allows the employee to work their hours in shifts in order 
to complete other personal tasks, spend quality time with family, and provide childcare at home. Historically, the literature on telecommuting has held that workers and companies participate in telecommuting because it allows the company to enjoy lower facility costs, lower overhead costs, easier accommodations of those with disabilities (1990 Americans with Disabilities Act), reduced infrastructure and insurance costs, and reduced labor costs (Bailey and Kurland 2002, 387; Grantham and Paul 1995). Furthermore, increased workplace flexibility promotes stronger individual well-being, organizational success, and positive social capital (Hill et al. 2010, 357).

San Jose is the tenth largest city in the United States, third largest in California, largest in Santa Clara County, home to over a million people, boasting a reputation as one of the safest cities in the United States, home to a newly renovated international airport, and is the Capital of Silicon Valley because it hosts the "world's largest concentration of technology-based companies," (Envision San Jose 2040 General Plan 2011, 7). These high-tech companies include Adobe Systems, Cisco Systems, eBay, and Maxim Integrated. San Jose is a very progressive city and has a formal telecommuting policy; however, the policy is not effectively enforced. According to 2010 Census data, of the 435,824 members comprising the San Jose workforce who are San Jose residents, 338,893 or approximately 78 percent of them drove alone to work (U.S. Census Bureau 2010, ACS 3 Table B08101). By comparison, roughly 17,208 out of 435,824 workers (over 16 years of age) or 3.9 percent of workers in San Jose telecommute to work (U.S. Census Bureau 2010, ACS 3 Table B08101). Between 2008 and 2010 the average commute time for San Jose workers over sixteen years old was 25.1 minutes (U.S. Census Bureau Table GCT0801); however, many workers who are employed in San Jose do not live in San Jose. Interestingly, more individuals telecommute than take public transportation $(15,278$ persons or 3.5 percent) establishing telecommuting as a relatively popular option in San Jose (U.S. Census Bureau 2010, ACS 3 Table B08101).

Telecommuting can reduce automobile vehicle miles traveled (VMT) and therefore directly reduce air pollution. According to Grantham and Paul (1995), telecommuting in California resulted in an increase of employee productivity by 16 percent and a decrease of VMT by 20-40 percent during multiple studies from 1990 to 1992 in the San Francisco Bay Area. The reduced need for infrastructure may have significant land use implications as companies may not need to lease large office complexes and cities may be able to dedicate lands slated for office development to another use. However, it should be noted that while telecommuting can reduce commuter traffic, it can also promote recreational and social travel as well as urban sprawl (Geels and Smit 2000,878). These extra trips outside of normal commuting (like grocery shopping or coffee stops) replace the commuting trips and reduce the effectiveness of telecommuting as a VMT and greenhouse gas (GHG) reducer. 


\section{2: Research Question}

What are the best telecommuting policies that government agencies and companies in San Jose can adopt in order to reduce vehicle miles traveled and greenhouse gas emissions due to commuting?

\section{3: Audience}

This report is intended for planners at the City of San Jose and their employees as well as San Jose companies as an introduction to telecommuting as a viable commuting option and a way to reduce VMTs and GHGs. It will assess whether or not telecommuting should be adopted in San Jose and what policies would be appropriate. This report may also be useful to other large metropolitan areas considering telecommuting programs and policies. Those who read the report should gain a better understanding of telecommuting's benefits and drawbacks and if telecommuting is a viable option for the organization or individual.

\section{4: Relevance}

Telecommuting policies may help reduce a company's or government's GHG emissions and overall environmental impact by limiting or reducing the need for a work commute for their employees. Telecommuting also opens the doors to more globalized communication and hiring where commuting or relocating is impractical, expensive, and adds to pollution. Given the state of the economy, low- or no-cost strategies to fight GHGs and global climate change like telecommuting are essential, especially in a city as large as San Jose. This report will focus on determining the impact that telecommuting has on reducing VMT and GHGs. It is important to note that VMT reductions is a tool to reduce GHGs and should not be the focus of GHG policies (Boarnet 2010, 587). Also, GHG policies should be specific to the local context because what works in one area will not necessarily respond to the distinct nature and circumstance of another area (Boarnet 2010,587). For example, some cities or regions may not be able to use wind power as a viable GHG reduction (reducing the reliance on fossil fuels) because the area does not have enough wind.

The argument is also made by the federal and California government that telecommuting by a portion of government employees is essential as it provides a fail-safe for government services if an emergency is to occur, effectively disabling the main office (www.opm.gov 2012, 1-3 and California Department of General Services 2010,4). Telecommuters would be able to assist during emergencies, like an earthquake, without having to be on the work campus and maintain continued operations of emergency services and communications. In order to establish a background of the precedence of telecommuting, federal, state, county, and local government telecommuting policies and programs will be explored in this report. Then, cities and companies with successful programs will be discussed and analyzed.

Another important driver behind telecommuting is the adoption of AB32 (California Global Warming Solutions Act of 2005) and SB375 which requires California to reduce GHG emissions to 1990s levels by 2020 (Malaczynski and Duane 2009, 71). VMT and vehicle emissions per mile 
are leading contributors by the transportation industry to GHG levels in California, releasing roughly one million metric tons of carbon dioxide annually per 200,000 passenger cars (Malaczynski and Duane 2009, 78). One way to achieve the reduction rates of 169 million metric tons of carbon dioxide by 2020 is to remove 33.8 million cars from the roads throughout California; San Jose and the larger Bay Area can play a significant role in promoting commuting alternatives like telecommuting to achieve these goals (Malaczynski and Duane 2009, 80). SB375 (2008) established the framework for land use GHG emission reduction strategies while allowing the local Metropolitan Planning Organizations (MPOs) to choose what elements and programs will be changed and initiated within their regional transportation plans (Boarnet 2010, 593).

VMT reductions are encouraged throughout the reviewed literature as a leading way to reduce transportation related GHGs. Also, telecommuting was cited as a tool to reduce the transportation VMTs, specifically those related to commuting alone in a passenger vehicle. A study by Brown, Balepur, and Mokhtarian concluded that if an interaction is initiation through ICTs due to telecommuting, then the commute trip would be substituted for a telecommuting trip (Brown, Balepur and Mokhtarian 2005, 88). Furthermore, the telecommuting communications would continue via the internet and phone instead of generating an in-person encounter, further supporting the substitution of the commute (Brown, Balepur and Mokhtarian 2005, 88). Choo and Mokhtarian's study further supported this argument stating that upon completing an extensive literature review, telecommuting was revealed as having a substitution effect on travel and reduces VMT (Choo and Mokhtarian 2007). Atkyns, Blazek, Roitz, and AT\&T measured the impact of telecommuting on AT\&T's workforce commuting impacts; they found that AT\&T's program prevented 110,000 VMTs and roughly 5.1 million gallons of gasoline from being used in 1992 (Atkyns, Blazek, Roitz, and AT\&T 2002).

Cox discussed the potential of telecommuting to improve overall quality of life for workers and companies by cutting cost, increasing productivity, and expanding the network of available employees (Cox 2009). As of 2000, 4.2 million U.S. workers telecommuted at least some time from home, reducing their overall driving by one-third (Cox 2009). This led to a reduction of $\mathrm{CO}_{2}$ emissions by 55 million metric tons annually (roughly 1 percent of all U.S. carbon emissions), all with virtually no cost (Cox 2009). Companies like Sun Microsystems have 48 percent of their workforce telecommuting part-time, saving the company roughly \$387 million dollars in facility costs annually (Cox 2009). Bose and Luo provided examples of company specific savings from telecommuting programs; strategies such as cloud computing, virtualization, and telecommuting can reduce the need for facility infrastructure up to 80 percent and data center energy consumption by up to 40 percent (Bose and Luo 2009). Other Silicon Valley companies like IBM, Sun Microsystems, and Cisco have harnessed these strategies for over a decade (Bose and Luo 2011).

Cuenot, Fulton, and Staub discussed the opportunity for modal shifts which would cut energy usage and carbon emissions from private automobiles to trains, bikes, buses, and teleworking 
by using the BLUE shifts scenario. BLUE shifts estimate a reduction of 20 percent in carbon emission and energy usage from mode shifting (Cuenot, Fulton, and Staub 2012). The authors argue that these shifts are possible if policies are drafted that require modal shifts (Cuenot, Fulton, and Staub 2012). They conclude that if the entire worldwide workforce telecommuted one day per week, it would reduce travel by 20 percent (Cuenot, Fulton, and Staub 2012). San Jose planning officials and company policy makers can help the City and the State meet their GHG and VMT reduction goals (like AB32 and SB375) by exploring the potential and implementing telecommuting policies. New strategies like telecommuting learn from the past, utilize the technologies of today, and have the potential to transport us into a future less reliant on fossil fuels.

\section{Bay Area leads 'mega-commuter' list}

Some cities the Census Bureau notes as having the highest percentage of full-time workers who are mega-commuters. with morning commutes of at least 50 miles and 90 minutes.

San Francisco, Peninsula and East Bay Santa Clara County New York-Northern New Jersey-Long Island Washington-Arlington-Alexandria. Va. Trenton-Ewing, N.J. Los Angeles-Long Beach-Santa Ana Salinas Boston-Cambridge-Quincy. Mass.-N.H. Gulfport-Biloxi, Miss. Hinesville-Fort Stewart. Ga.

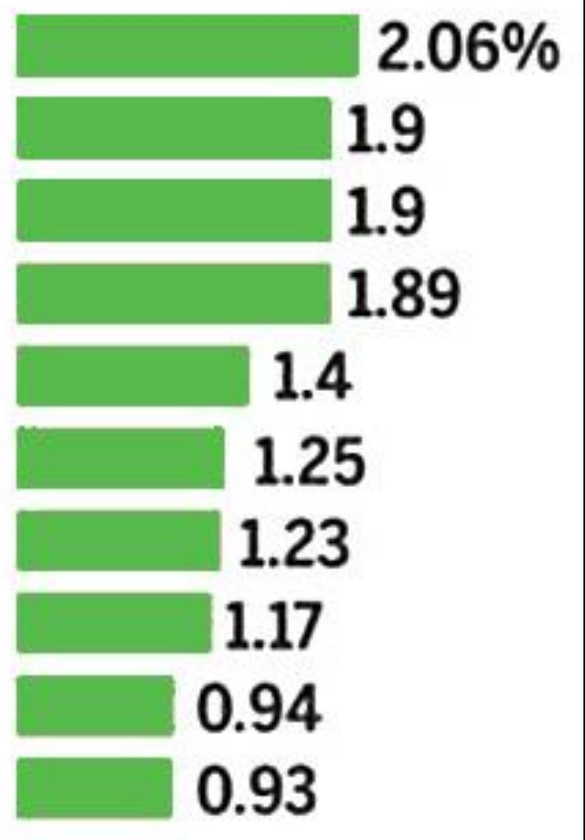

Source: U.S. Census Bureau

2006-2010 American Community Survey

BAY AREA NEWS GROUP 
A February 5, 2013 KQED article "San Francisco-Oakland Area has the Nation's Second Worst Traffic" by Laird Harrison explains that the San Francisco-Oakland area has tied for the second worst traffic in the U.S. with commuters wasting an average of 61 hours getting to work in 2011 (Harrison 2013). Harrison explained that as the economy improves and unemployment decreases, traffic congestion worsens as more drivers join the commute trek (2013). This increase in car usage means that commuters in single-occupancy vehicles must allow almost four times as long to get to work so they are not late (Harrison 2013). San Jose was listed as having slightly less congestion with commuters wasting thirty-eight hours in traffic in 2011 (Harrison 2013). The U.S. Census Bureau released a new report on March 5, 2013 entitled "Mega Commuters in the U.S." which lists the San Jose-Sunnyvale-Santa Clara metro area as having the highest percent of mega commutes with the highest distance traveled (Rapino and Fields 2013 , 4). This region was second only to the San Francisco-Oakland-Fremont metro area (Rapino and Fields 2013,4). Mega commutes are defined as one-way commute trips of ninety minutes or more or fifty miles or more (Rapino and Fields 2013, 1). Figure 3 uses the Mega Commuters' study information to show how the Bay Area is leading the nation in the highest percentages of "mega commutes" (Rosenberg 2013). It should be noted that all the commuters from San Francisco, Peninsula, and East Bay and Santa Clara County referenced in Figure 3 are part of one mega-region called the Bay Area.

\section{15: Hypothesis}

According to the Metropolitan Transportation Commission (MTC), the impact of telecommuting in the Bay Area is minimal, but the cost-effectiveness is high (MTC 2009, 96). Precedence for telecommuting in San Jose has been set by Cisco Systems Inc., with the average employee telecommuting two days a week and with 83 percent of workers reporting that communication remained the same if not improved while telecommuting (Gurchiek 2009). Cisco's 2009 Teleworker Survey revealed that 40 percent of their employees do not live in the same city as their managers and 2008 GHG emissions were reduced by 47,320 metric tons due to increased telecommuting (Cisco Systems 2009). Their survey also showed that the average round-trip distance for commuters was thirty miles a day (Cisco Systems 2009). Other local companies like Google boast up to 50 percent of their workforce as telecommuting on a parttime basis and Sun Microsystems engages their employees in their "iWork" telecommuting program (MTC 2009, 95). Other success stories include small businesses like Alpine Access located in Golden, Colorado. The company employs fifty individuals, four of which do not telecommute regularly and the company has experienced increases in work-life balance and financial benefits for the company (Alpine Access).

On a state level, Arizona's 1996 telecommuting program stated that by 1998, 15 percent of Arizona government employees would telecommute in order to reduce ozone pollution. In addition, Washington established goals of increasing the government telecommuting workforce by 21,600 employees in order to reduce nitrogen oxides (Transportation Demand Management Institute 1997). Phoenix, Arizona has reduced their daily VMT by 1.3 million commuters and 
prevented 47,000 pounds of GHGs per day from commuting trips while utilizing telecommuting programs (MTC 2009, 96). This further supports the hypothesis that telecommuting programs are a low-cost way to help reduce GHGs due to increasing VMT. MTC's 2012 legislative program goal 3.C supports telecommuting as a tool to reduce GHGs and VMT, specifically geared to help California achieve its SB375 goals (MTC 2012, 2).

San Jose government and San Jose companies should establish programs that include incentives for telecommuting instead of drive-alone commutes for their employees in order to reduce GHGs caused by VMT. San Jose employers can experience many benefits including a reduction in parking lot facilities. Figure 4 shows a sea of cars in a San Jose high-tech company's parking lot, some of which could be removed or replaced by infill development if some employees participated in telecommuting. Cities like Berkeley are establishing programs that promote telecommuting at least one day per week to reduce automobile usage and the accompanying VMT and GHGs for their employees, acting as the "Model Employer" (Hurrell and Cruz 2006, 20). According to the MTC 2009 report on transit, land use, and GHGs, one of their strategies to reduce GHGs is to "increase use of telework and teleconferences" through city and county programs (MTC 2009, 95). Specifically, MTC cites programs led by Council of Governments (COG) in Washington D.C., Denver, and Santa Barbara that have produced impressive results.

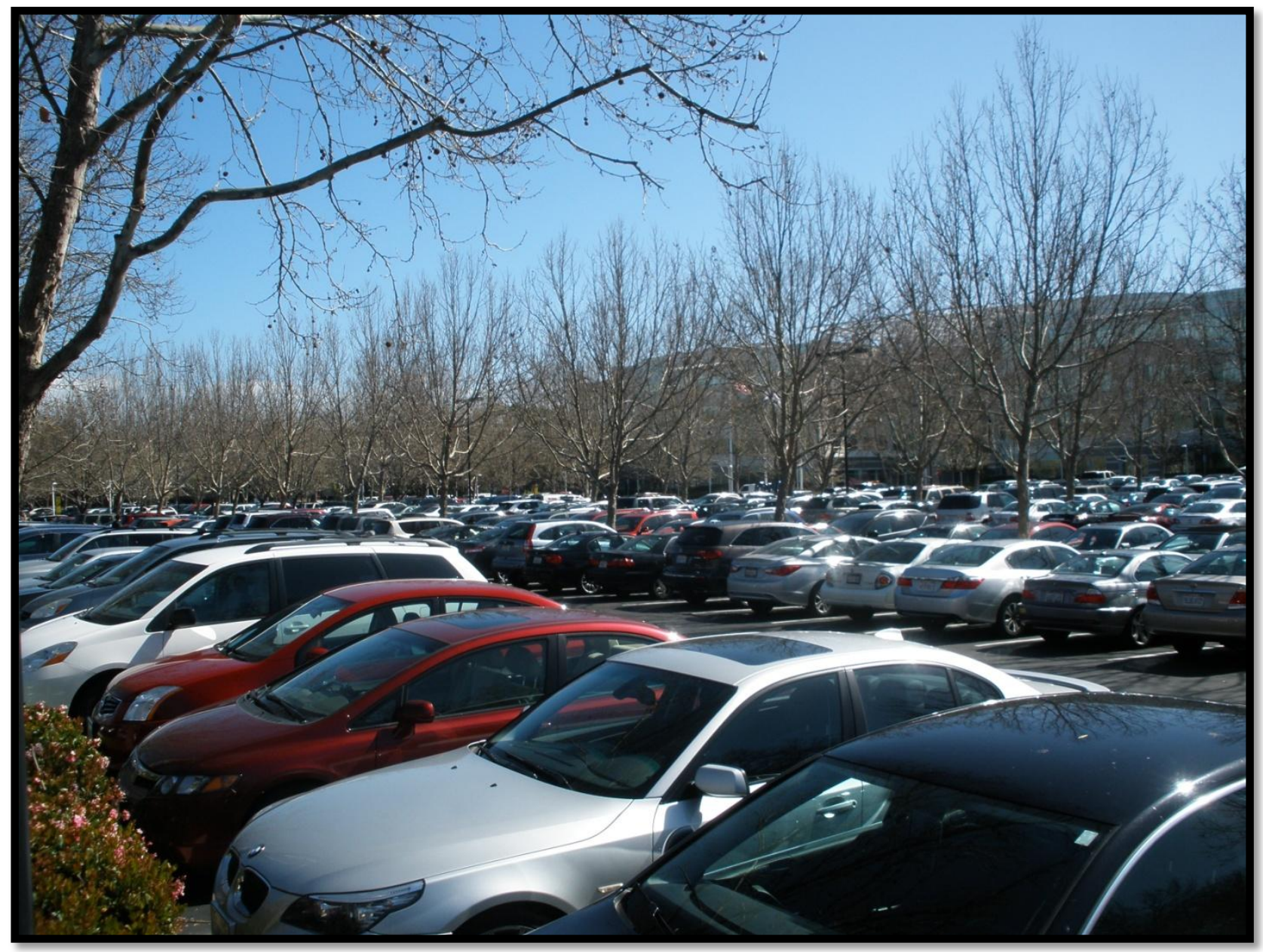

Figure 4: An Ocean of Cars at a San Jose High-tech Company 
MTC increased teleworking frequency to an average of one to three days a week at only $\$ 100$ per person (MTC 2009, 95). Choo, Mokhtarian, and Salomon (2005) explored the long-term impact of telecommuting on VMT. In general, as travel increases, telecommuting increases and reduces travel; this means that as a person's commute distances become greater, they are more likely to participate in telecommuting. This would be considered a substitution effect. In the end, the authors are 90 percent confident that telecommuting reduces VMT, but this reduction is relatively small (roughly 2 percent). The authors conclude that even though the savings are modest, they are very cost-effective savings when compared to alternative VMT reduction strategies like mass transit improvements, warranting deeper analysis into telecommuting as a VMT reduction tool. These results prompt further investigation into telecommuting's ability to reduce VMTs and GHGs as it has been successful in other cities and organizations at a policy level.

\section{6: Report Structure}

The remainder of this report will be laid out in the following manner. The first section details what telecommuting policies and programs exist in various government agencies and their impact on VMTs and GHGs. The second section will be a description of the methodologies used, including interviews and synthesis techniques. The third section will detail the findings from the literature and interviews. The fourth section will be the synthesis of telecommuting policies. The fifth section will detail the findings of the study and the final section will make recommendations. 


\section{2: Setting the Stage: Telecommuting Policies and Programs and Their Impact on VMTs and GHGs}

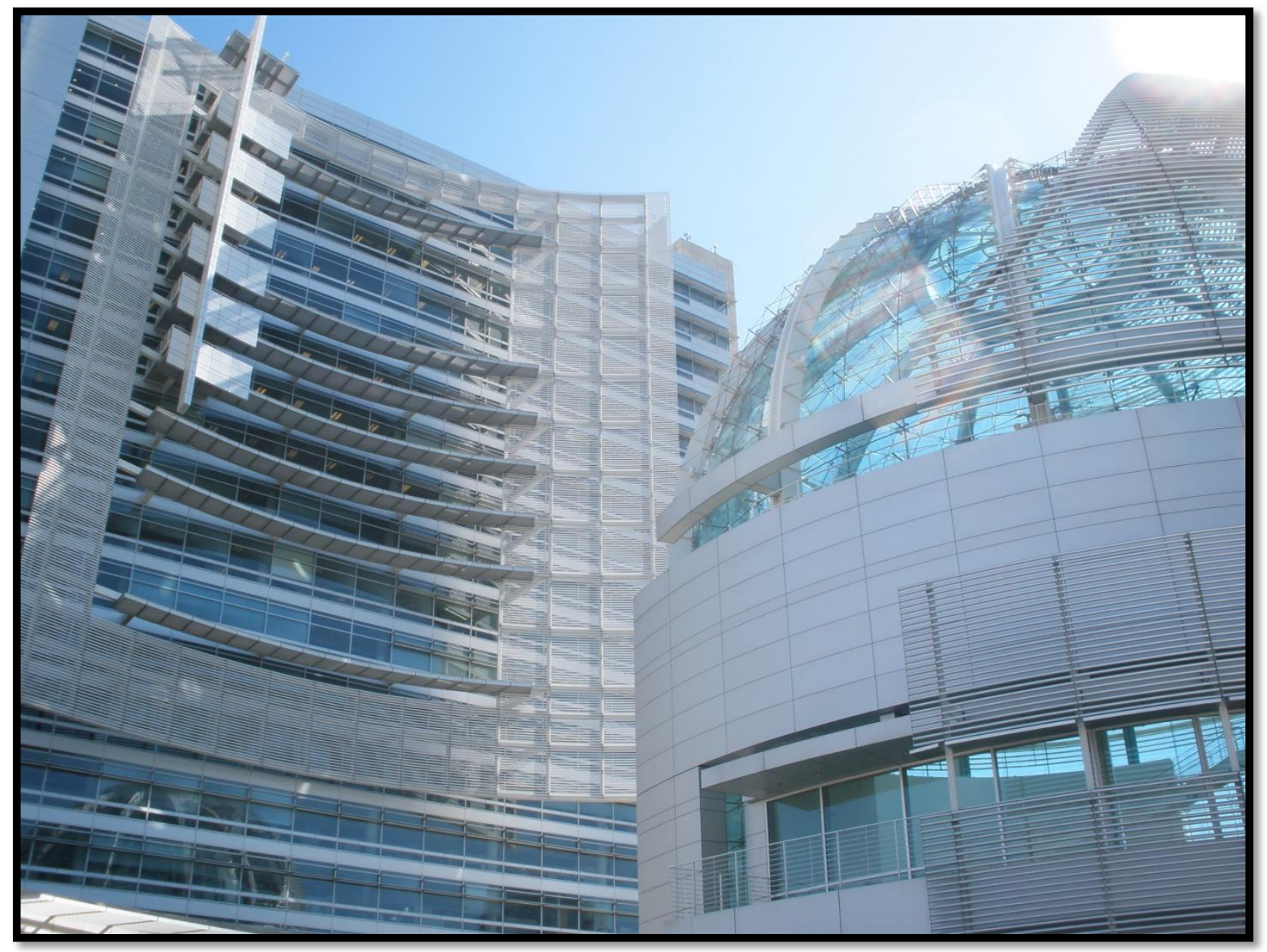

Figure 5: San Jose City Hall

In order to establish a background of the precedence of telecommuting, select telecommuting policies and programs will be explored across all levels of government, including federal, state, county, and local. Then, cities and companies with existing programs will be discussed. Following each section, a discussion of the potential for telecommuting to reduce VMTs and GHGs for each city or company is analyzed. This section provides a backdrop for the telecommuting discussion as it indicates what the precedent is, if any, for telecommuting and what programs or laws are in place that promote or inhibit telecommuting.

\section{1: United States Federal Telecommuting Policies}

At the federal level, the first legislative mandate for telecommuting was established in 2000 (see $\S 359$ of Public Law 106-346) (United States Office of Personnel Management 2012, 1). The law states that "[e]ach executive agency shall establish a policy under which eligible employees of the agency may participate in telecommuting to the maximum extent possible without 
diminished employee performance" (United States Office of Personnel Management 2012, 1). Further legislation adopted in 2004 specified the amount of the federal workforce that must participate in telecommuting for different agencies (United States Office of Personnel Management 2012, 2). Most federal telecommuters only telecommute part-time, which varies in amount among agencies (United States Office of Personnel Management 2012, 2). The federal government clearly states that telecommuting is not an intrinsic right, but a privilege that is required to be offered by their agencies in order to help recruit and retain the best workers, better balance work-home life, reduce traffic congestion and air pollution, reduce the impact of urban infrastructure, save tax dollars by reducing government real estate costs, and ensure that the nation is protected even in times of crisis (United States Office of Personnel Management 2012,1-3). The federal government cites that better work-life balance assists in stress reduction, less distractions in the workplace, and encourages engagement among the organization (freedom leads to organizational commitment) (United States Office of Personnel Management 2012, 8).

The Telework Enhancement Act of 2010 enacted by the federal government mandates that federal agencies must establish telecommuting policies that are made available to all federal employees who qualify. Table 1 in the following paragraph lists jobs that may qualify for telecommuting. Two examples of job limitations that restrict telecommuting qualification include those that require constant in-

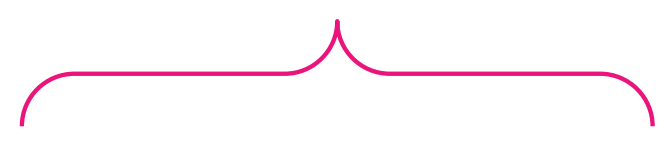

"I believe that it's time we stopped talking about family values and start pursuing policies that truly value families, such as paid family leave, flexible work schedules, and telework, with the federal government leading by example." -President Obama, 2008 IMB study (Caldow 2009, 11)

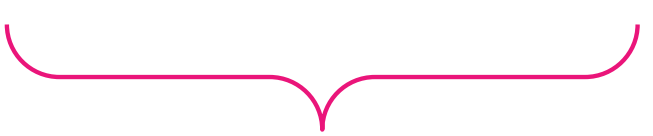
person interaction and specific equipment that is not available outside the office. This program was established to reduce the costs associated with facility operations, improving employee productivity and quality of life, reducing traffic congestion, improving air quality, and enhancing emergency response. The law specifically cites a February 2010 winter storm that prohibited employees from accessing their jobs and how telecommuting policies should be in place in order to allow for continued government operations (U.S. Senate 2010, 1-2). The law observes that managers tend to be hesitant to adopt or support telecommuting among their employees due to fears of lack of control and lost productivity, but those fears are typically relieved when they experience firsthand the benefits of telecommuting. Also, managers and employees must be trained in order to ensure telecommuting program success (U.S. Senate $2010,6)$. Even though new telecommuting programs may increase administrative costs, the 
federal government estimates that savings due to benefits like less office space will result in no significant net impact on the federal budget (U.S. Senate 2010, 12-13).

The U.S. Department of Transportation's (U.S. DOT) Research and Innovative Technology Administration (RITA) released a report detailing the transportation implications of telecommuting. They found that many pilot or demonstration programs conducted were implemented at a relatively small scale with a limited range of workers, therefore reducing the study's ability to be used as a generalization of telecommuting's effectiveness (U.S. DOT RITA, 4). However, they were able to conclude that telecommuting can reduce "the number of commuting vehicles and thus contribute to the attainment of cleaner air and congestion mitigation" (U.S. DOT RITA, 5). Federal programs like the Flexible Workplace Project and laws such as the Intermodal Surface Transportation Efficiency Act of 1991 (ISTEA) and the Clean Air Act enable the federal government to actively pursue telecommuting as a viable Transportation Demand Management (TDM) option to reduce congestion and improve air quality (U.S. DOT RITA, 5-6). In order to better understand the potential application of telecommuting as a VMT and GHG reducer, jobs must be identified as having the ability to telecommute. This study formed the following list:

Table 1: Jobs with Telecommuting Potential (Part- or Full-Time)

\begin{tabular}{|c|c|c|c|}
\hline Accountant & Broker & Journalist & Software engineer \\
\hline Actuary & $\mathrm{CEO}$ & Industrial engineer & Statistician \\
\hline $\begin{array}{l}\text { Administrative } \\
\text { assistant clerk/clerk } \\
\text { typist }\end{array}$ & Consultant & Lawyer & Stock analyst \\
\hline Advertising executive & Contract monitor & Manager & Stockbroker \\
\hline Agent & Computer scientist & Market analyst & Surveyor \\
\hline Analyst & Data entry specialist & Professor/teacher & Systems analyst \\
\hline Architect & Data entry clerk & Programmer & Telemarketer \\
\hline Appraiser & Economist & Purchaser & Telephone operator \\
\hline Artist (commercial) & Employment & $\begin{array}{l}\text { Receptionist } \\
\text { (sending/receiving } \\
\text { electronic mail) }\end{array}$ & Training designer \\
\hline Auditor & Engineer interviewer & Realtor & Word processor \\
\hline Bankers & Financial analyst & Researcher & Writer \\
\hline Bookkeeper & Graphic artist & School administrator & \\
\hline
\end{tabular}

Not only do the types of jobs need to be identified as telecommuting compatible, but a more solid definition of what constitutes telecommuting must be adopted in order to better estimate the past, present, and future impacts of telecommuting on transportation (U.S. DOT RITA, 20). In other words, before potential VMTs and GHGs can be calculated, a more solid definition of what constitutes a telecommuter must be established. 
From programs like the Puget Sound multi-employer program and organizations like The Hawaii Telework Center, the State of California, and Los Angeles County, this study concluded that telecommuting results in the following travel behavior and transportation changes (U.S. DOT RITA, 23):

\section{Reduced commute travel}

- No increase in non-commute travel

- Fewer linked trips

- Activities and destinations relocated closer to home

- Residential relocation probability is mixed

\section{Air quality will be affected by telecommuting through VMT reductions as well as the following, resulting in positive and negative air quality impacts (U.S. DOT RITA, 23):}

- Telecommuters may keep older, less fuel efficient cars

- Less peak-time travel

- More driving on less congested, urban roads

\section{Telecommuting may result in changes in mode choice among workers as follows (U.S. DOT RITA, 24):}

- Telecommuters leave carpool/vanpool arrangements and may drive alone more often

- Telecommuters use less transit on telecommuting days resulting in mass transit revenue losses

- Telecommuter's household members may start driving the car if the telecommuter is not using it

- Telecommuters may use a bike or walk instead of drive to local destinations

According to the U.S. DOT, Nilles presents an example of why telecommuting is a difficult Transportation Demand Management (TDM) strategy through an example addressing land use and sprawl, and may be used to explain its almost "catch-22" relationship with air quality, energy usage, and transportation.

"If it is primarily on a part-time basis, people who move further out into rural areas will still press for improvements in transportation infrastructure, thereby encouraging sprawl. If, on the other hand, telecommuting is full-time, which is more likely for telework centers, transportation infrastructure is less likely to be expanded. Thus, the more-rural locations will still be relatively unattractive for commuters, and sprawl will be discouraged. In addition, the telecommuters' constant presence will encourage development of neighborhood stores and services, diminishing the motivation to travel to larger urban locations" (U.S. DOT RITA, 29). 
Ultimately, the U.S. DOT study concludes that telecommuting is not a standalone solution for transportation, energy, climate change, or land use problems. Rather, telecommuting must work in conjunction with other strategies to achieve the overarching goals of society like improved air quality and reduced traffic congestion.

A study by Fran Irwin entitled "Gaining the Air Quality and Climate Benefit from Telework" was funded by the U.S. Environmental Protection Agency and AT\&T Foundation. This study found that telecommuting can achieve both environmental (pollution and traffic congestion reductions) and business (reducing costs associated with transportation and facilities) goals (Irwin 2004, 6-7). Irwin concluded that telecommuting helped reduce GHG emissions by reducing or avoiding the commute, limiting physical business trips (especially via airplane), and reducing energy usage by office facilities (heating, cooling, lights, and equipment operation) (Irwin 2004, 7-9). Irwin cites a study by Choo, Mokhtarian, and Solomon which found through a U.S. aggregate time series analysis that telecommuting does reduce overall commuting VMTs (Irwin 2004, 7). Office complexes in the U.S. use one-fifth of all commercial energy, most of that attributed to air conditioners, lighting, and office equipment (Irwin 2004, $8)$.

\section{2: State of California Telecommuting Policies}

The State of California shares a similar ideology with the federal government regarding telecommuting. California's government states that telecommuting is vital because it "can help reduce air pollution, traffic and parking congestion, and demand for office space," as well as aid in an emergency (California Department of General Services 2009). Telecommuting legislation is filed under Government Code Sections 14200-14203, expressing that every state agency has the authority to implement telecommuting programs as a viable work option for employees (California Department of General Services 2010, 4). According to California's 2010 Telework Program Policy and Procedures guide, telecommuting offers the following benefits:

- "Improved employee performance and morale

- Optimum use of office facilities

- Reduced absenteeism

- Improved employee health and wellness

- Increased work options for employees on temporary limited duty

- Improved air quality and reduced traffic and parking congestion

- Enhanced working experience and opportunities for those with mobility restrictions

- Effective continuation of business as part of a disaster recovery or emergency plan," (California Department of General Services 2010,4)

California's telecommuting policy allows part-time and full-time telecommuting when appropriate (California Department of General Services 2010, 12). Full-time telecommuting is only allowed when it is "necessary to accommodate medical restrictions or physical disabilities, recruit and retain highly skilled expertise or is contingent on the needs of the job" (California Department of General Services 2010, 12). Also, the policies state that telecommuting 
arrangements are not meant to be a substitute for child or elder care services; therefore, telecommuters must "treat the [home] work area as an official state office work area during work hours" with as few personal interruptions as possible (California Department of General Services 2010,17). Similar to the federal government, California has strict policies detailing security when telecommuting.

The Telework Research Network developed the California Public Workforce Telework Savings Calculator from over 500 "case studies, scholarly reviews, research papers, books, and other documents" in order to best quantify the effects of telecommuting on governments and companies (Telework Research Network 2011, 4-5). Their bottom line estimates indicate that California's potential government facilities could save upwards of $\$ 563$ million a year, which roughly equates to a savings of $\$ 1,360$ per telecommuter per year (Telework Research Network $2011,6)$. The calculator estimates that telecommuting would increase productivity, saving the government $\$ 2.6$ billion annually (roughly $\$ 6,200$ per telecommuter per two remote working days) (Telework Research Network 2011, 7). The Telework Research Network concludes that the State of California, along with local governments, can prevent the release of greenhouse gases equivalent to removing 40 percent of single occupancy drivers from Sacramento's streets and save $\$ 6$ billion annually from reducing oil imports and traffic accidents (Telework Research Network 2011, 16).

\section{3: Bay Area Telecommuting Policies}

Unlike many other counties, the Bay Area (comprised of nine counties) has collectively established telecommuting policies. Therefore, for the purpose of this research, it seems pertinent to discuss both Bay Area and Santa Clara County telecommuting policies independent of one another. Telecommuting's importance was established by the federal and state government and further solidified at the Bay Area level. According to the Metropolitan Transportation Commission (MTC) and the Association of Metropolitan Planning Organizations (AMPO), the Bay Area's local governments must comply with AB 32, SB 375, Governor Schwarzenegger's 2005 Executive Order S-3-05 (which limits California's future GHG emissions), and Assembly Bill 1493 reduces GHG emissions from new passenger cars in California starting model year 2009 (MTC and AMPO 2009,5). This study finds that Bay Area cities can use the Air Resources Board's (ARB) EMFAC2007 model to calculate household $\mathrm{CO}_{2}$ emissions (MTC and AMPO 2009, 10). MTC's Executive Director Steve Heminger furthered this discussion in his 2010 presentation explaining California's "three pronged approach" to reducing GHGs: cleaner vehicles, cleaner fuels and more sustainable communities (Metropolitan Transportation Commission 2010,3). One of their TDM goals is to increase total Bay Area telecommuting participation to above the current five percent to at least 10 percent (Metropolitan Transportation Commission 2010, 16). This strategy, among many others, is what MTC suggests California do in order to reduce their VMTs and GHGs in order to be compliant with the current climate change legislation. 


\section{4: Santa Clara County Telecommuting Policies}

As of 2009, Santa Clara County (SCC) does not have specific policies to support a telecommuting program (SCC 2009, 38). SCC's Climate Action Plan for Operations and Facilities recognizes that telecommuting programs have similar benefits as listed under the federal and state sections (SCC 2009, 38). SCC believes that a formal policy would be helpful in addressing telecommuting's "client, service and operational needs" (SCC 2009, 38). SCC has estimated that 4.8 percent of their workforce telecommutes at least one day a week, reducing GHGs by roughly 164 metric tons (SCC 2009, 39 and ACS 2009-2011 3 year estimate, Table DP03). The County is also investigating flexible work schedules in addition to telecommuting, which would allow employees to work longer hours on fewer days per week and reduce their total GHG production (SCC 2009, 39). SCC details VMT and GHG emissions estimates used to determine what changes in their fleet should be made to comply with laws and regulations, but telecommuting is not yet considered a viable TDM strategy (SCC 2009, 50). Telecommuting could help the county cope with the negative effects of its sprawling urban form and large corporate campuses which add to the region's growing VMTs and GHGs.

\section{5: Overview of Telecommuting Polices at the City Level}

The purpose of these case examples is to determine if telecommuting policies exist among cities comparable to San Jose in population, diversity, or urban form. If policies do exist, they will be examined and compared to other city policies. If policies do not exist and high levels of telecommuting exist, then further investigation into the potential causes will be completed. The goal of these case examples is to understand if formal telecommuting policies do affect the prevalence of telecommuting in cities and, if so, what the best combination of policies should be. Another aspect of these case examples will be to determine if telecommuting is adopted for purely quality of life initiatives or if cities utilize telecommuting as a TDM tool to reduce VMTs and GHGs. These results may be crucial in understanding if San Jose government and San Jose companies should decide to more aggressively pursue telecommuting in formal policies and programs or if telecommuting effects the greatest VMT and GHG change when left on an informal case-by-case basis.

A total of five cities were chosen for this case review: San Jose, Los Angeles, San Diego, San Francisco, and Denver. These cities were chosen due to their similarity to San Jose in population size, demographic diversity, or urban form. The following sections provide more details about each city. See Table 2 and Table 3 for more information.

\subsection{1: City of San Jose}

The City of San Jose will serve as the focus of this research project. San Jose has a population of 945,942 (U.S. Census Bureau 2010, Table DP-1) with approximately 16,673 individuals or 3.8 percent of its population telecommuting annually (ACS 2009-2011 3 year estimate, Table DP03). The city is ethnically diverse with a White population of 42.8 percent, Black population of 3.2 percent, American Indian and Alaska Native population of 0.9 percent, Asian population of 32.0 percent, Native Hawaiian and other Pacific Islander population of 0.4 percent, some other race 
of 15.7 percent, and two or more races at 5.0 percent (U.S. Census Bureau 2010, Table DP-1). San Jose is approximately 176 square miles in area with roughly 5,358 persons per square mile (U.S. Census 2010 QuickFacts).

\section{Table 2: Population and Telecommuter Background Data}

\begin{tabular}{|c|c|c|c|c|c|}
\hline & San Jose & Los Angeles & San Diego & San Francisco & Denver \\
\hline $\begin{array}{l}\text { Total } \\
\text { Population }\end{array}$ & 945,942 & $3,792,621$ & $1,307,402$ & 805,235 & 600,158 \\
\hline $\begin{array}{l}\text { Total square } \\
\text { miles }\end{array}$ & 176 & 468 & 325 & 46 & 153 \\
\hline $\begin{array}{l}\text { Persons/square } \\
\text { mile }\end{array}$ & 5,358 & 8,092 & 4,020 & 17,179 & 3,922 \\
\hline $\begin{array}{l}\text { \# of } \\
\text { telecommuters }\end{array}$ & 16,673 & 97,939 & 43,397 & 30,841 & 18,094 \\
\hline $\begin{array}{l}\text { Telecommuter's } \\
\% \text { of workforce }\end{array}$ & $3.8 \%$ & $5.7 \%$ & $6.9 \%$ & $7.1 \%$ & $5.9 \%$ \\
\hline
\end{tabular}

Sources: ACS 2009-2011 3 year estimate, Table DP03; 2010 U.S. Census Table DP-1; U.S. Census 2010 QuickFacts

The City of San Jose's TDM program aims to reduce VMTs by promoting alternatives such as telecommuting (City of San Jose General Plan 2011, 49). A policy San Jose has implemented is the TDM Policy TR-7.1 which requires large employers to "develop and maintain TDM programs to reduce the vehicle trips generated by their employees," (City of San Jose General Plan, 49). Also, according to San Jose's Sustainable Energy Policy Action Plan (under Energy Action item six) San Jose aims to reduce VMT and air pollution as well as "increase employee satisfaction by reducing drive time thus increasing quality of life," (City of San Jose Action Plan 2003 , 15). They suggest that telecommuting may lead to a reduction in the city's operating and facilities costs and increasing "employee satisfaction by increasing flexibility of work location and/or time," (City of San Jose Action Plan 2003, 15). However, the writers of the City's Action Plan suggested that this was a low priority for the City and should be put on hold.

The City of San Jose adopted ten Green Vision goals aiming to "transform San Jose into a world center of Clean Technology innovation, promote cutting-edge sustainable practices, and demonstrate that the goals of economic growth, environmental stewardship and fiscal responsibility are inextricably linked" (City of San Jose Green Vision Goals 2007). These goals were implemented in 2007 and the City aims to accomplish all the goals by 2022 (City of San Jose Green Vision Goals 2007). The Green Vision goals were reviewed and none of the goals addressed mode shifts or telecommuting. Perhaps the lack of focus on transportation or mode shifts is due to the relatively short time span that the City set for the goal to be reached. The goals do address transportation, but only in regards to reducing tailpipe emissions through alternative fuel usage (City of San Jose Green Vision Goals 2007). 
Table 3: City Demographics

\begin{tabular}{|c|c|c|c|c|c|}
\hline & San Jose & Los Angeles & San Diego & San Francisco & Denver \\
\hline White & $42.8 \%$ & $49.8 \%$ & $58.9 \%$ & $48.5 \%$ & $68.9 \%$ \\
\hline Black & $3.2 \%$ & $9.6 \%$ & $6.7 \%$ & $6.1 \%$ & $10.2 \%$ \\
\hline $\begin{array}{l}\text { American } \\
\text { Indian and } \\
\text { Alaska } \\
\text { Native }\end{array}$ & $0.9 \%$ & $0.7 \%$ & $0.6 \%$ & $0.5 \%$ & $1.4 \%$ \\
\hline Asian & $32.0 \%$ & $11.3 \%$ & $15.9 \%$ & $33.3 \%$ & $3.4 \%$ \\
\hline $\begin{array}{l}\text { Native } \\
\text { Hawaiian } \\
\text { and other } \\
\text { Pacific } \\
\text { Islander }\end{array}$ & $0.4 \%$ & $0.1 \%$ & $0.5 \%$ & $0.4 \%$ & $0.1 \%$ \\
\hline $\begin{array}{l}\text { Some other } \\
\text { race }\end{array}$ & $15.7 \%$ & $23.8 \%$ & $12.3 \%$ & $6.6 \%$ & $11.9 \%$ \\
\hline $\begin{array}{l}\text { Two or more } \\
\text { races }\end{array}$ & $5.0 \%$ & $4.6 \%$ & $5.1 \%$ & $4.7 \%$ & $4.1 \%$ \\
\hline
\end{tabular}

\subsection{2: City of Los Angeles}

The city of Los Angeles has a population of 3,792,621 (2010 U.S. Census Table DP-1) with approximately 97,939 individuals or 5.7 percent of its population telecommuting annually (ACS 2009-2011 3 year estimate, Table DP03). The city is ethnically diverse with a White population of 49.8 percent, Black population of 9.6 percent, American Indian and Alaska Native population of 0.7 percent, Asian population of 11.3 percent, Native Hawaiian and other Pacific Islander population of 0.1 percent, some other race of 23.8 percent, and two or more races at 4.6 percent (U.S. Census Bureau 2010, Table DP-1). Los Angeles has a higher Black population and significantly lower Asian population than San Jose. Los Angeles is approximately 468 square miles in area with roughly 8,092 persons per square mile (U.S. Census 2010 QuickFacts). Los Angeles is nearly four times larger than San Jose in population and has a slightly higher percentage (5.7 percent) of telecommuting participation (ACS 2009-2011 3 year estimate, Table DP03). The city also has significantly more land area and persons per square mile than San Jose.

Jack M. Nilles' work paved the way for telecommuting success in Los Angeles. He produced the 1993 report "City of Los Angeles Telecommuting Project" in order to evaluate the effectiveness of telecommuting for the city, identify its major impacts, and make recommendations regarding the future of telecommuting programs and policies. The project started in 1989 with five hundred telecommuters and five hundred non-telecommuters as a control group (Nilles 1993, 1). The analysis revealed that roughly sixteen thousand City employees were eligible to telecommute at least part-time (Nilles 1993, 3). One project aim was to reduce air pollution by 20 percent by 2010 in response to the Southern California Air Quality Management District's XV Air Quality Management Plan (Nilles 1993, 2). The results were a proportional decrease in air 
pollutants relative to the number of telecommuters, reducing carbon monoxide on an average of 276 pounds (lbs) and nitrogen oxides by seventeen lbs annually for each telecommuter (Nilles 1993, 3). This translates to roughly 6.2 million lbs of unreleased carbon monoxide for the City each year (Nilles 1993, 4). Nilles recommended continuing and increasing telecommuting in Los Angeles by integrating telecommuting into the TDM strategies $(1993,5)$. Los Angeles still has a modest telecommuting program. A formal telecommuting program guide and telemanager handbook are available on the City of Los Angeles' website. Specific telecommuting VMT and GHG calculations are discussed by Nilles and may be available through an interview with the City's Employee Benefits Office. These findings will inform the policy recommendations portion of this report.

\subsection{3: City of San Diego}

The city of San Diego has a population of 1,307,402 (2010 U.S. Census Table DP-1) with approximately 43,397 individuals or 6.9 percent of its population telecommuting annually (ACS 2009-2011 3 year estimate, Table DP03). The city is ethnically diverse with a White population of 58.9 percent, Black population of 6.7 percent, American Indian and Alaska Native population of 0.6 percent, Asian population of 15.9 percent, Native Hawaiian and other Pacific Islander population of 0.5 percent, some other race of 12.3 percent, and two or more races at 5.1 percent (U.S. Census Bureau 2010, Table DP-1). San Diego has a slightly less diverse population than both San Jose and Los Angeles. The city is approximately 325 square miles in area within area

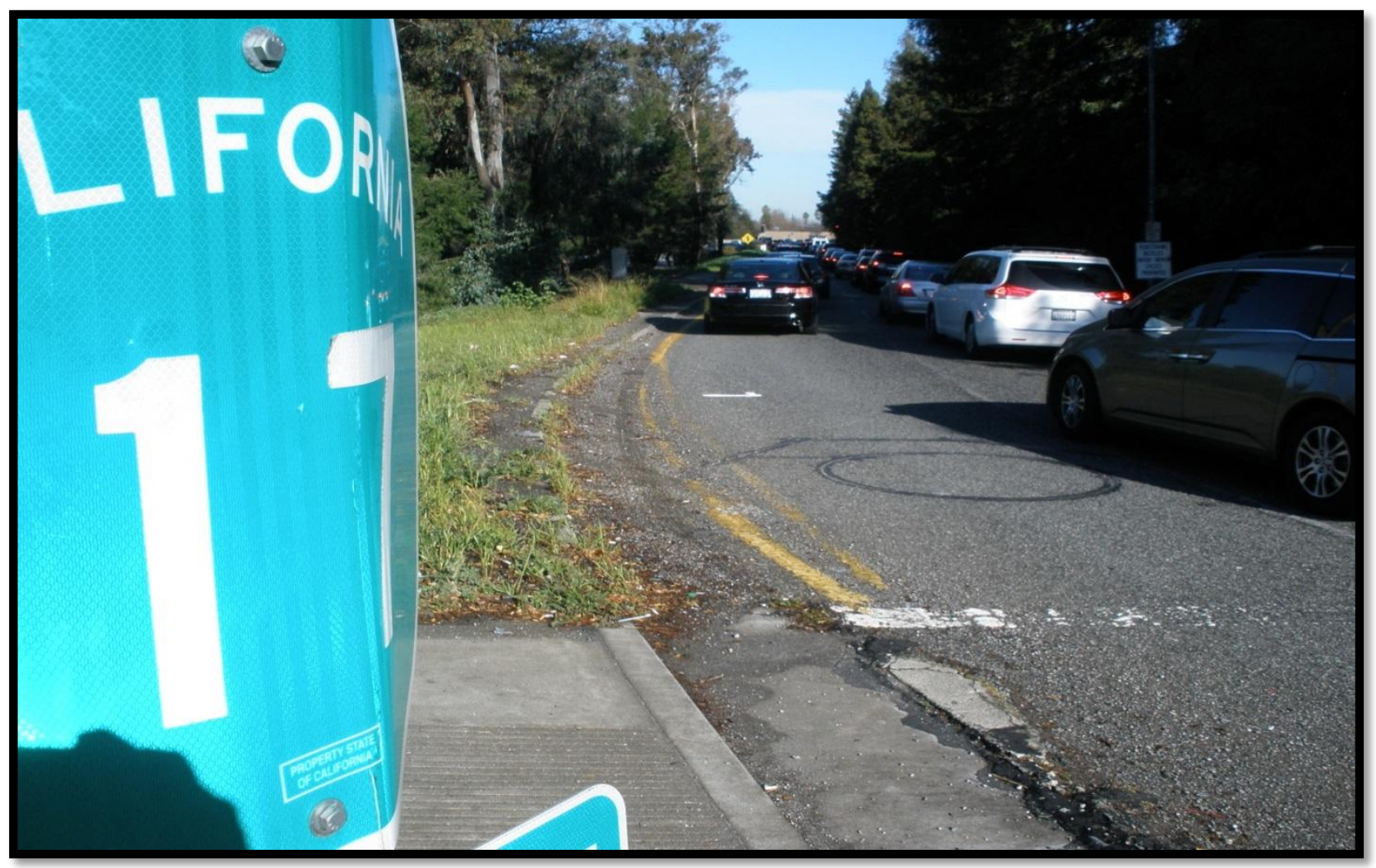

Figure 6: Traffic Congestion at Highway 17 Entrance in San Jose 
roughly 4,020 persons per square mile (U.S. Census 2010 QuickFacts). San Diego is closer in population to San Jose than Los Angeles and has a higher telecommuting rate than San Jose or Los Angeles at 6.9 percent (ACS 2009-2011 3 year estimate, Table DP03). The city also has more land area than San Jose, but a significantly smaller population density.

The City's 2005 Climate Protection Action Plan lists telecommuting as a tool used to meet their GHG reduction goals (City of San Diego Environmental Services Department 2005, 23). San Diego's Energy Policy Initiatives Center 2009 report “Reducing Greenhouse Gases from OnRoad Transportation in San Diego County" provides an analysis of local government policy options including a telecommuting policy that would aim for 20 percent of all commuters to telecommute two days a week by 2020 (Energy Policy Initiatives Center 2009, 3). If the 20 percent is achieved, they estimate that telecommuting can reduce targeted GHG emissions by 22 percent (Energy Policy Initiatives Center 2009, 7). They elaborate that telecommuting would be one of eleven policies that would be used in conjunction to reduce GHGs; other strategies include mass transit, smart growth, high occupancy/toll lanes (HOT) congestion pricing, parking cash out, reduce congestion (highway expansion), roundabouts, vanpools, traffic signal retiming, park and ride, and road freight to rail (Energy Policy Initiatives Center 2009, 11). Telecommuting would provide the next largest level of GHG reductions (mass transit system being number one) with the lowest implementation cost (Energy Policy Initiatives Center 2009, 13). Methods to calculate GHGs and VMTs are mentioned and briefly explained, but an interview with an appropriate City representative may provide further elaboration. These findings will inform the policy recommendations portion of this report.

\subsection{4: City of San Francisco}

The city of San Francisco has a population of 805,235 (2010 U.S. Census Table DP-1) with approximately 30,841 individuals or 7.1 percent of its population telecommuting annually (ACS 2009-2011 3 year estimate, Table DP03). The city is ethnically diverse with a White population of 48.5 percent, Black population of 6.1 percent, American Indian and Alaska Native population of 0.5 percent, Asian population of 33.3 percent, Native Hawaiian and other Pacific Islander population of 0.4 percent, some other race of 6.6 percent, and two or more races at 4.7 percent (U.S. Census Bureau 2010, Table DP-1). San Francisco has a similar ethnic diversity to San Jose. The city is approximately 46 square miles in area with roughly 17,179 persons per square mile (U.S. Census 2010 QuickFacts). San Francisco has a similar population size to San Jose and has a significantly higher telecommuting rate than San Jose and Los Angeles, but has a closer telecommuting rate to San Diego at 7.1 percent (ACS 2009-2011 3 year estimate, Table DP03). The city also has one-third the land area of San Jose and three times more persons per square mile than San Jose making it the densest city of those selected for this comparison.

In 2005, Mayor Gavin Newsom released the memorandum "Executive Directive to Implement Telecommuting Pilot Program," requiring City departments to allow eligible staff to telecommute in order to reduce energy used, VMTs, GHGs, and traffic and parking congestion (the list includes more goals, but they are not directly relevant to this study) (Newsom 2005, 1). 
San Francisco's “2011 Climate Action Strategy for San Francisco's Transportation System” lists telecommuting as a tool that the community can use to reduce their VMTs and GHGs (SFMTA 2011, 44). According to San Francisco's telecommuting policy, they require that telecommuting be available to as many City departments as possible while emphasizing that it is "a privilege, not a right" (City of San Francisco Department of Human Resources 2005, 8). This notion of telecommuting being a privilege is also emphasized by the federal government. In response to Mayor Newsom's memorandum, two relevant goals of the pilot program are to reduce VMTs, GHGs, parking congestion, and traffic congestion and better utilize City resources like office space (City of San Francisco Department of Human Resources 2005, 8). Another requirement is that the program must be "cost neutral" which means no additional costs may be generated by the creation or maintenance of the program (City of San Francisco Department of Human Resources 2005, 11). San Francisco's telecommuting packet provides a detailed outline for how a program and the associated paperwork should appear and will be used to expand future sections of this report. These findings will also develop the policy recommendations portion of this report.

\subsection{5: City of Denver}

The city of Denver has a population of 600,158 (2010 U.S. Census Table DP-1) with approximately 18,094 individuals or 5.9 percent of its population telecommuting annually (ACS 2009-2011 3 year estimate, Table DP03). The city is the least ethnically diverse in this study with a White population of 68.9 percent, Black population of 10.2 percent, American Indian and Alaska Native population of 1.4 percent, Asian population of 3.4 percent, Native Hawaiian and other Pacific Islander population of 0.1 percent, some other race of 11.9 percent, and two or more races at 4.1 percent (U.S. Census Bureau 2010, Table DP-1). Denver has a higher White population and significantly lower Asian population than San Jose. The city is approximately 153 square miles with roughly 3,922 persons per square mile in area (U.S. Census 2010 QuickFacts). Denver has a smaller population than all the other cities in this study and has a higher telecommuting rate than San Jose and Los Angeles, but a lower rate than San Diego and San Francisco at 5.9 percent (ACS 2009-2011 3 year estimate, Table DP03). The city has similar land area to San Jose, but fewer persons per square mile than San Jose.

According to the Denver Regional Council of Government's (DRCOG) Telework Toolkit, telecommuting is a way to maintain productivity even when employees are ill or prevented from attending work due to bad weather conditions (Denver Regional Council of Governments 2006, 1). DRCOG's website provided three case examples detailing telecommuting success stories from Alpine Access, Rocky Mountain Center for Health Promotion and Education, and SKLD Information Services (Denver Regional Council of Governments 2012). SKLD Information Services' 2001 pilot program prevented 190,000 commute miles annually and 11,320 lbs of pollution through mostly full-time telecommuting employees (Ride Arrangers Denver Regional Council of Governments (3), 1). The Rocky Mountain Center for Health Promotion and Education program reduced commute times by 120 minutes per day by telecommuting, reduced VMTs by 28,000 miles annually, and prevented 1,630 lbs of GHGs annually (Ride 
Arrangers Denver Regional Council of Governments (2), 2). Further solidifying Denver's commitment to telecommuting, its 36 Commuting Solutions organization provides guidance to companies to help them create and maintain their telecommuting program (36 Commuting Solutions 2012, 1).

Ramaswami et al.'s 2012 article “Quantifying Carbon Mitigation Wedges in U.S. Cities: NearTerm Strategy Analysis and Critical Review" looked at the potential of cities to reduce their GHG emissions through existing technologies (Ramaswami et al. 2012, 3629). Telecommuting is considered an employer-based commuter program which was shown to displace more than half of the car usage among employees participating in this program (this high percentage was achieved even when only 11 percent of the participants used telecommuting instead of another employer-based commuter program) (Ramaswami et al. 2012, 3636). This reduction resulted in 36 less car commute miles traveled per week per worker and a reduction in office facility size, which may have balanced out increased home energy usage (Ramaswami et al. 2012, 3636). The study concluded that even though telecommuting has great potential to reduce GHGs, it is currently underutilized; however, telecommuting is cited as a logical and effective near-term strategy that takes advantage of existing technologies (Ramaswami et al. 2012, 3638-3639).

According to a study commissioned by Microsoft Corporation, Denver is the fourth best city in the U.S. for telecommuting among medium- to large-sized cities (Convey 2010). Microsoft's "Work Without Walls" 2011 telecommuting report, prepared by Ipsos Public Affairs, and Microsoft's main website's 2011 article “Remote Working Now a 'Business Imperative'” said Denver was among 15 other cities (including Los Angeles, San Francisco, and Phoenix), that had roughly 50 to 65 percent of their companies within each city with formal telecommuting policies allowing employees to participate in telecommuting (Microsoft (1) 2011, 3 and Microsoft (2) 2011).

From these findings, Denver appears to be a good model regarding successful telecommuting programs. An interview with the 36 Commuting Solutions or the DRCOG may determine how the VMTs and GHGs were calculated and if and how San Jose can be guided by Denver's example. 
This page intentionally left blank. 


\section{3: The Findings from the Literature and Interviews}

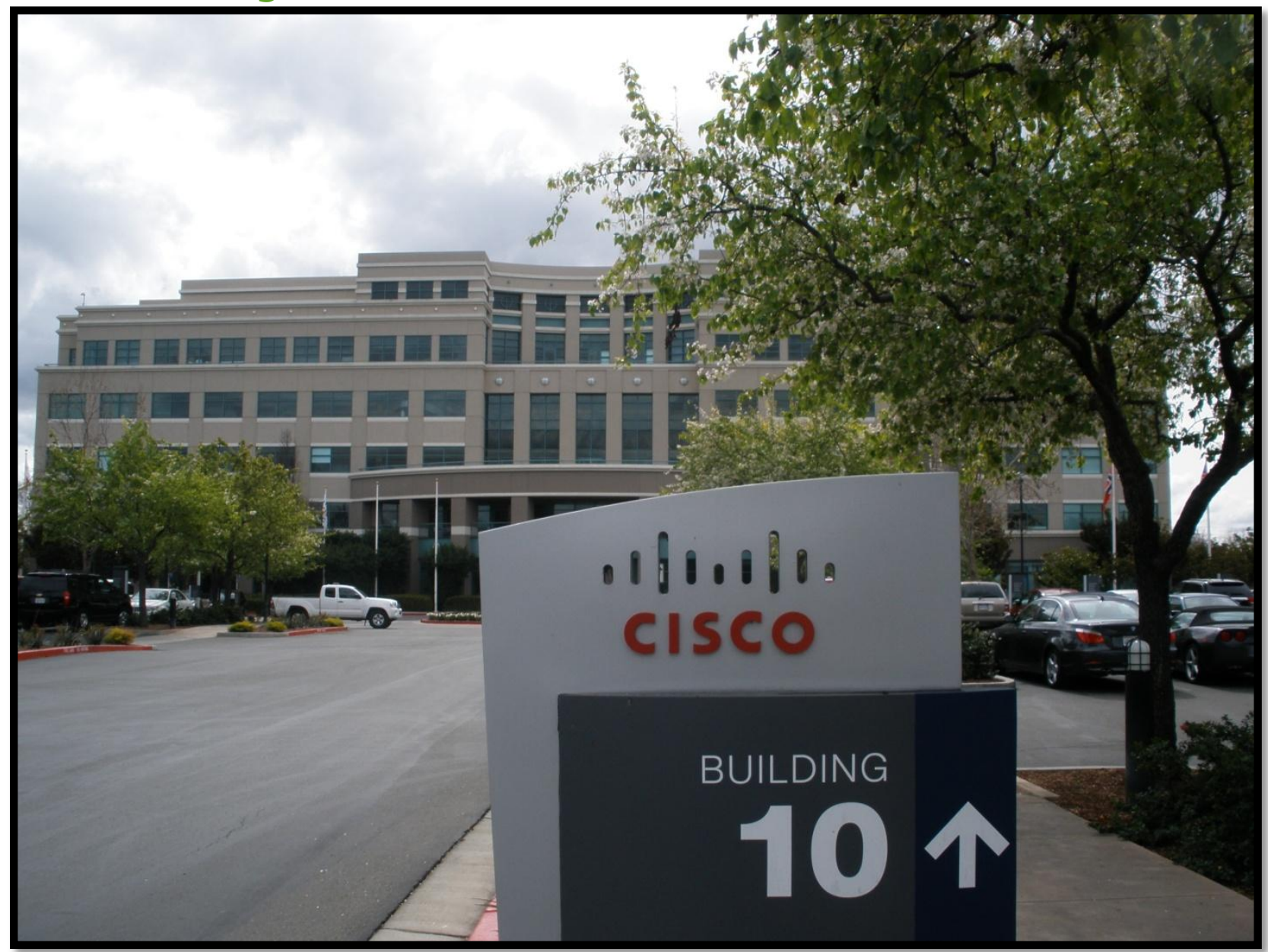

Figure 7: Cisco Systems Headquarters in San Jose

\subsection{Methodologies}

Three particular methodologies were used in this report and are described below. First, interviews were conducted with San Jose government and company officials. Second, the interviews and literature were analyzed and synthesized to determine common themes, differences, and innovative ideas or areas of improvement for telecommuting programs and policies. Third, telecommuting policies from both government agencies and companies were reviewed to determine their completeness and areas for improvement.

\subsection{1: Methodology for Interviews}

\section{Defining the Questions}

The following questions were used to guide the interviews. When needed, additional probing questions were asked to clarify answers or gather more important information. If an interviewee did not know the answer to a question, the question was skipped. 


\section{Confirmation of my research:}

1. My research indicates that [subject city or company] does/does not have a telecommuting policy or program. Is this the case?

\section{Telecommuting in formal literature:}

1. Are telecommuting policies present in [city or company]'s formal documents? For example, a general plan or employee HR memo? What are these policies?

\section{References:}

1. May I have copies of any reports and plans produced by [city or company] about telecommuting policies and programs?

2. Also, if statistics exist regarding [city or company] telecommuting programs, vehicle miles traveled and greenhouse gas reductions, may I have a copy?

For the following section, please answer the first set of questions if you have a telecommuting program. Please answer the second set of questions if you do not have telecommuting policies.

\section{[YES] Effectiveness of telecommuting policy:}

3. Has the policy or program been effective at reducing the overall vehicle miles traveled and greenhouse gas emissions for [city or company] and specifically involved employees? Can you provide examples?

4. What, if any, policies did [city or company] reference when drafting your telecommuting policies?

5. What selection criteria did you use to pick those example policies?

6. Would you consider your policies transferable to other [cities or companies]? Please explain.

7. If yes, have these reductions helped [city or company] work toward any greenhouse gas reduction goals set forth by the federal, state, county, or city government? In what ways? How was effectiveness measured? Were specific models used?

\section{[NO] Reasons for lacking formal policies:}

8. Is [city or company] aware of the benefits of telecommuting? Please explain the known benefits.

9. Why does [city or company] not have formal telecommuting policies or programs?

10. Have studies assessed the effectiveness of such policies and found them to be ineffective? Please explain.

\section{Data inquiries:}

11. How many employees does your organization have? 
12. What number of employees are eligible for telecommuting?

13. How do you define eligibility?

14. What is the average one way commute distance for your employees? For telecommuters?

15. Of the employees that telecommute, what number or percentage telecommutes full-time and what percentage telecommutes part-time?

16. For part-time telecommuters, what is the average number of days that they telecommute per week?

\section{Interview Approach and Findings}

Emails and follow-up phone calls were made to make initial contact with the interviewees. In some instances, one interviewee would use their network to provide another individual who wanted to contribute to the project. All of the interviews were conducted either over the phone, through email or in-person at their office and lasted an average of 30-45 minutes. All of the participants were adults and received a copy of the interview questions prior to the interview. There were roughly fifteen questions asked of the interviewees. The interviews were semistructured, where the questions were used to guide the discussion, but the interviewees were encouraged to add more details or answer questions out of order.

A coding scheme was not utilized in the traditional sense for this report. The interviews were transcribed into a table and the themes were extracted from the text. These themes were placed into two tables, one holding interview themes that were also present in the literature review and one holding interview themes not present in the literature review. Interviewees were from mostly San Jose based government agencies and companies. Some of them did participate in telecommuting while others did not. Knowledge about telecommuting varied greatly among all those interviewed.

\section{2: Methodology for Interview and Literature Analysis and Synthesis}

The interviews and literature were analyzed and synthesized to determine common themes, differences, and innovative ideas or areas of improvement for telecommuting programs and policies. The themes from the literature and interviews were placed in tables and common themes were gleaned. From this process, themes that were common among the literature and interviews became apparent as well as those that the two sources did not share. These resulting tables were used to synthesize the information.

\section{3: Methodology for Policy Review}

The telecommuting policies from both government agencies and companies were reviewed to determine their completeness and areas for improvement. Similar to section 3.2, the common themes were placed into one table, while the different and innovative ideas were put into another table and synthesized. 
The sixteen interviews conducted for this study were documented and common themes were placed into Table 5 in Appendix A: Interviews in order to be compared to the policies. In the next two columns of this table, the interviewee's company was listed in addition to key themes presented in the report's literature review. About half of the themes brought up in the sixteen interviews were supported by the literature review. In other words, only half of the themes derived from the interviews are relevant to telecommuting and the role it plays in reducing VMTs and GHGs.

The first section Table 5 in Appendix A will discuss common themes in both the literature and the interviews. The second section will discuss the findings in the literature that were not discussed in the interviews. The third section will discuss the themes present in the interviews, but not the literature.

\section{4: Themes Present in Both the Literature and Interviews}

\subsubsection{Telecommuting's Effect on Land Use}

Eight studies in the literature looking at telecommuting's effect on land use concluded that telecommuting can cause urban sprawl and increase physical travel. Three studies by Ettema (2010), Mannering and Mokhtarian (1995), and Tayyaran and Khan (2007) showed that personal characteristics such as having children or a partner increase the likelihood that an individual will telecommute because individuals without children or a partner are more likely to live near the city center, while those with children or a partner are more likely to live in more suburban or rural areas, thus increasing commuting distances (11). This finding was supported by the interviews which cited work-life balance due to familial obligations, such as children or appointments, and increased flexibility as an important reason why individuals requested or participated in telecommuting. Interestingly, most of the individuals interviewed cited using a car to drive to work if and when they did not telecommute and suggested that they lived in more typical San Jose suburban environments. As all of the companies interviewed were located in and around the greater San Jose area, it can be inferred that the interview participants would live in and around San Jose, thus living in typical San Jose suburban sprawl developments. None of the participants cited using public transportation as a second commute option to the single-occupancy vehicle, but rather listed telecommuting as the second best alternative. This testimony by a 511 representative suggests that while the car is the preferred mode of transportation, telecommuting is still more popular than buses or rail (Interview with a 511 representative, February 2013).

These findings were supported by six studies which indicated that telecommuting can induce urban sprawl, unsustainable growth patterns, and decentralization due to the increasing likelihood of residential relocation by telecommuters in order to access more green space or attractive housing (Rhee 2009; Tayyaran and Khan 2007; Marvin 1997; Ettema 2010; Audirac 2002, 216; Hjorthol 2002, 452). Furthermore, telecommuting can promote urban sprawl because the increased commute distance is considered an acceptable cost to the telecommuter if they can live in an environment that they find more pleasing, specifically near green space, and provides 
access to faster transportation modes (i.e. freeways) (Ettema 2010; Plaut 2005; Tayyaran and Khan 2007, 1332). These factors support the decentralization of cities into more sprawling suburban and rural areas (Tayyaran and Khan 2007, 1332). These findings are interesting as San Jose, being the self-proclaimed Capitol of Silicon Valley, has a plethora of high-tech and other telecommuting capable industries within its boundaries. Telecommuting has been around since the 1970s, during which time sprawling urban patterns and decentralization were developing at a vigorous rate. This implies that telecommuting was not seen as a viable alternative to the car until more recently, and is still not considered a top choice for discouraging urban sprawl. Is this due to the findings in this literature, that telecommuting promotes urban sprawling development because work is no longer defined by location? Is this freedom from a commute destination outside of the house promoting decentralized living away from congested urban cores to less central open, green spaces? Corpuz argues that telecommuters are ideally individuals who live far from the city center as they have longer commutes $(2001,11)$. The removal of these individuals from the road would reduce traffic congestion, travel time, and travel costs, as was often cited by the interviewees and main motivators to telecommute, but the increased or promoted sprawling land uses may cancel out any GHG savings gained by the reduced or eliminated commute.

Two researchers discovered that telecommuting encourages urban sprawl and reduces fuel and emissions savings due to residential relocation, increased driving at lower speeds, increased commute distances, and increased car usage by individuals who do not normally commute because of decreased congestion (Marvin 1997, 59; Rhee 2009). One author argued that inflexible zoning codes may also increase urban sprawl and residential relocation to more suburban or rural communities as some metropolitan areas have prohibitive zoning in place that prevents telecommuters from working at home (Rhee 2009). One study by Marvin (1997) found that telecommunications on a whole can "dissolve the glue that holds cities together" resulting in the dissolution of cities (53). The author argues that if electronic travel replaced physical travel, populations would be inert without the need to move at all (Marvin 1997, 53). From this we can surmise that individuals will not need to live near the city core, but rather can live in less sustainable suburbs because they do not need to access the city's resources.

Furthermore, telecommuting can increase interactions over the internet which can spur more interactions in person (Marvin 1997, 54). One study contradicts these findings, concluding that telecommuters tend to make fewer trips, suggesting that induced travel is not a negative externality of telecommuting (Corpuz 2011, 11); however, this finding was unique perhaps due to the robust telecommuting policies in place referenced by the author and may not be representative of telecommuting's true substitution effects (Corpus 2-11,4). This conclusion warrants further investigation in the final report to corroborate these findings. As telecommuting is enabled by Information and Communications Technologies (ICTs), where one works is no longer important. So can it be argued that even if an individual is working away from the city center in a suburban environment, he is reducing his overall carbon footprint by reducing the need for office space and parking, eliminating another car from already congested 
Bay Area freeways allowing traffic to flow easier? A threshold of effectiveness must be established in order to understand at what rate telecommuting outweighs the negative effects of sprawl. Also, not all of the benefits of telecommuting can be bundled under VMT and GHG savings as personal employee benefits like better work-life balance and less stress from commutes. Company benefits like reduced office space needs and access to a larger range of talented employees may prove more effective, profitable, and beneficial to society than just removing the commute.

In sum, the literature research and interviews suggest that telecommuting can have a significant effect on land use by increasing unsustainable urban growth patterns and car usage. This conclusion supports the hypothesis that telecommuting can reduce commuting, but significant rebound effects may result in a negative net impact (i.e. increased urban sprawl and commuting VMT when a car is used). This suggests the hypothesis that telecommuting can reduce VMTs is not fully supported by this section of the research. However, the increases in productivity, work-life balance, reduced traffic congestion, and cost savings may equal or outweigh the negative externalities of urban sprawl. Income is also a factor. The literature states that higher income telecommuters prefer to live in more suburban and rural areas whereas lower income telecommuters are more likely to live in urban environments (Ettema 2010, 22). Since San Jose's most likely telecommuters are government officials and high-tech company employees, the salary ranges would be more in line with middle to higher income individuals. Does that mean that San Jose telecommuters would prefer suburban or rural settings? This suggests that a cultural or behavioral shift must occur among more affluent telecommuters in order to promote more urban dwelling. Perhaps this also means that cities should increase the suburban feel of more open and green space in the form of parks and gathering areas to appeal to these higherincome telecommuters.

\subsection{2: Effective Telecommuting Policies and Programs}

The interview findings suggest that a formal telecommuting policy is best when a company is attempting to make any reductions in costs and GHG emissions, as well as productivity and other benefits, from telecommuting participation. A 511 representative said that they encourage employers to adopt formal telecommuting policies because formal policies: make clear the expectations, what is covered under workers' compensation, how the telecommuter is expected to communicate, what technologies must be used, and how to maintain productivity (Interview with a 511 representative, February 2013). The 511 representative said that informal policies may have the same components as a formal policy, but they are usually less detailed and do not outline to the same level the expectations of the employee and do not provide the same protections for the employer (Interview with a 511 representative, February 2013). 511 suggested that after a formal policy is implemented, both the managers and the employees that will be participating in telecommuting should attend trainings before participation can begin (Interview with a 511 representative, February 2013). These trainings would help dispel the negative myths and misconceptions among managers and employees in order to promote a healthy and successful telecommuting program. 
Lyon (2002) suggests that transport policy must directly address telecommuting in order to fully assess its potential at reducing travel (339). Benefits of telecommuting from a transport policy perspective include increased cost and travel savings for individuals and inexpensive implementation as a policy (especially when compared to car or public transit policies) (Lyons 2002, 344). The interviews with the City of San Jose and County of Santa Clara both support this assertion, the representatives all stating that telecommuting was difficult to implement when it was not incorporated into their legal documents (like general plans or TDM strategies) (Interview with a City of San Jose representative, February 2013; Interview with a County of Santa Clara representative, February 2013). Both the City and County have telecommuting officially listed or implied in their formal GHG and VMT plans and their effectiveness will be evaluated in the next section of the report.

The literature research suggests that telecommuting programs and policies must address organizational barriers in order to be successful. One author lists the barriers to telecommuting which include in-person contact, supervisor control, productivity, facilities access, job suitability, and company policy (Brewer $1998,97)$. Productivity is a hot issue of concern which many of the interviewees cited as a determinate of whether or not a telecommuting program would survive. Representatives from both Somas Mayfair, a local San Jose non-profit, and Partners Mortgage needed to use the flexibility of telecommuting while dealing with family and personal health issues (Interview with a Somas Mayfair representative, January 2013; Interview with a Partners Mortgage representative, February 2013). This time away from the office could have caused their work to go unfinished, but their managers allowed them to work from home or the hospital which allowed them to complete their tasks on time, meet the required objectives, and present their deliverables to their managers as expected. Also, the Partners Mortgage representative felt that communications with the manager were strong while telecommuting because they would have to make a conscious effort to plan their talks and be organized when meeting via phone

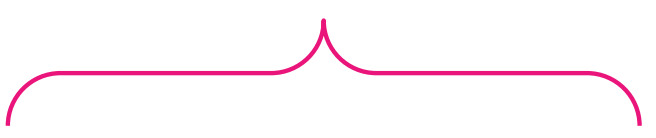

"[Workplace flexibility] is an issue that affects the wellbeing of our families and the success of our businesses. It affects the strength of our economy - whether we'll create the workplaces and jobs of the future we need to compete in today's global economy." - President Barack Obama, 2010 (Deloitte Development, LLC 2012, 8)

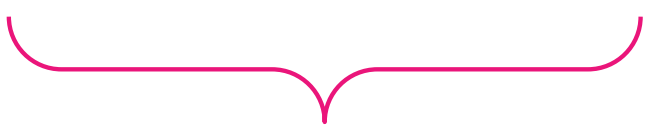
or Skype (Interview with a Partners Mortage representative, February 2013). 511, the County, Somas Mayfair, and Partners Mortgage all specifically stated that telecommuting allowed for employees to take fewer sick days because they could work at home when recovering from an 
illness and maintain productivity rates (Interview with a 511 representative, February 2013; Interview with a County of Santa Clara representative, February 2013; Interview with a Somas Mayfair representative, January 2013; Interview with a Partners Mortgage representative, February 2013).

In the two previous discussions, telecommuting was used as a means to promote work-life balance and allow an ill employee to keep up with their tasks. However, the interviews revealed that formal telecommuting policies are a requirement if employees plan on telecommuting on more than an ad hoc basis. During the interview, a Santa Clara County representative specifically mentioned manager support as a leading issue that must be addressed in order to make telecommuting successful (Interview with a County of Santa Clara representative, February 2013). 511 and the County worked together to draft a formal telecommuting policy that covers employees represented by the CEMA union. This telecommuting policy has "teeth" as it is written in the legal union contract and greatly reduces the management's personal perceptions of telecommuting that prevent eligible employees from telecommuting. Also, upper management usually supports telecommuting, but middle management may not like it because they are unable to see their employees at all times. This issue of needing micromanagement in order to know that the employees are really working makes it difficult to get buy-in from middle managers. This is an example where training would help alleviate the issue by dispelling myths and promoting a cultural management shift.

From an interview with a Cisco Systems representative, it was discovered that Cisco is a prime example of excellent managerial leadership regarding the support of telecommuting (Interview with a Cisco Systems representative, February 2013). Cisco has a formal telecommuting policy in place which allows eligible employees (roughly 90 percent of the entire workforce) to telecommute at least part-time (Interview with a Cisco Systems representative, February 2013). Cisco has seen great benefits from the implementation of telecommuting, from reduced facilities costs (they are actually selling some of their many buildings in North San Jose), to increased employee retention and recruitment, happier employees, and increased productivity (Interview with a Cisco Systems representative, February 2013). These examples answer part of the research question that formal telecommuting policies are beneficial to companies if they want their telecommuting programs to be successful.

While Brewer suggests that policy and organizational change must be enacted to successfully implement telecommuting, the process may not be simple as is evident by the following five articles. For instance, they provide contradicting views concerning how telecommuting policy should be structured, what the goals should be, and if behavioral change can influence success. Moore, Staley, and Poole Jr. (2010) argue that aiming to reduce VMT through policies is not an effective means to reduce GHGs; rather the goal should be to reduce the GHGs and any VMT reductions are an extra benefit (568). They argue that "policy approaches that emphasize technological innovation over behavioral shifts" are more successful and cost-effective (Moore, Staley and Poole Jr. 2010, 572). The authors conclude that "VMT is a proxy for mobility in high- 
income nations" reflecting implemented transit technology and individual freedom and flexibility. Therefore, the car is a sign of high-income flexibility and freedom due to its efficiency and its use cannot be reduced just by making driving more expensive. This is due to the fact that using the car is what allows individuals to gain wealth through lucrative job access and affordable housing opportunities (Moore, Staley and Poole Jr. 2010, 571-572).

These findings are further supported by Hartgen, Fields, Scott and San Jose's (2011) study which found that telecommuting is not very successful at spurring changes in travel behavior due to the higher cost of incentives and low GHG emissions reductions (14). This suggests that behavioral change is not the best way to decrease VMTs and associated GHGs, but rather financial incentives are more effective. However, the interviews contradicted this last argument of Hartgen, Fields, Scott and San Jose, stating that incentives were not always an additional cost. These could include incentives like flexibility of working times and spaces or commute relief through part-time telecommuting which would not cost the employer to implement. The only potential cost would be the initial cost to draft the telecommuting policy, which may be drafted with the help of other organizations or contractors. Companies like 511 offer training courses for managers and employees to ease them into the newly adopted telecommuting program, dispelling misconceptions and establishing the rules up front.

In contrast, Helling and Mokhtarian (2001) found that it was difficult to get individuals to participate in telecommuting without an incentive. This may mask the true desirability of telecommuting if individuals are only participating due to an incentive and suggest that telecommuting must have government or company intervention to be a viable VMT and GHG reducer (Helling and Mokhtarian 2001, 522). This finding was supported by the idea of fuel taxes, a government issued incentive, which can be used to reduce VMTs and increase telecommuting as it motivates the individual to travel less and invest in a more fuel efficient car (Difiglio and Fulton 2000, 664). The authors argue that fuel taxes are more efficient because they increase the cost of driving (Difiglio and Fulton 2000, 664). This study is contradictory to the Moore, Staley and Poole Jr. findings from the literature review which argued that increasing the cost of driving would not decrease car usage and increase the usage of other modes like telecommuting. This idea of incentivizing telecommuting to make it an attractive alternative may be addressed in how an employer both markets the option and if it is made a requirement by legislation or a policy. The interviews did not provide much insight into the effectiveness of monetary incentives for employees regarding telecommuting, but the Cisco representative did mention that telecommuting was an incentive for new hires and for retaining personnel. The employees expressed that the flexibility of part-time telecommuting allowed them to maintain better work-life balance while also retaining the "water cooler" experience of work place encounters.

By contrast, D. Salon et al. (2012) argue that policies which directly target VMT reductions through programs like telecommuting produce large benefits. A limitation of these programs is the voluntary nature of strategies like telecommuting which may limit the extent of reductions 
(500). However, they maintain that telecommuting is an affective VMT reduction policy strategy because it targets peoples' travel behavior. Therefore, if people change how they travel at a behavioral level, the changes may be long-lasting (D. Salon et al. 2012, 505). This finding was supported by Shaheen, Benjamin-Chung, Allen, and Howe-Steiger (2009) who argued that VMT reductions were seen by interviewed experts as the most effective policy strategies for meeting AB32 emissions requirements (49). Short-term GHG strategies included changing travel behavior through programs like telecommuting (Shaheen, Benjamin-Chung, Allen, and HoweSteiger 2009, 49; Brewer 1998, 94).

Mobility Management programs and policies can affect travel behavior. One strategy is "employer-based commute trip reduction" where telecommuting is encouraged part-time by employers in order to reduce commuting GHGs (Hartgen, Fields, Scott and San Jose 2011, 55). A second policy suggestion is to address contradictions between government and company policies, making company policies more flexible like government policies (Brewer 1998, 99). A third policy approach is treating Flexible Work Arrangements (FWAs) as an organizational change strategy where HR supports telecommuting through better policies preventing supervisor unwillingness from limiting telecommuting participation (Brewer 1998, 99-100). It seems that a combination of the above listed policies and suggestions would be the most effective way to promote telecommuting adoption and success; as with many GHG reduction strategies, not one, but many approaches work in conjunction to achieve the overall goal because they approach the problem from multiple angles. The local governments interviewed cited AB32 and other GHG regulations, whether self-imposed or federally mandated, as large motivators for including telecommuting as a commute alternative for their eligible employees. One City of San Jose representative stated that telecommuting was mentioned by the Envision San Jose 2040 General Plan in the "work from home" category in the baseline mode share for 2008 in Policy TR-1.1 and also includes areas where telecommuting is implied (Interview with a City of San Jose representative, February 2013). The City also included a reference of telecommuting in their TDM measures as a way to reduce VMTs. A second city representative stated that the city wants their employees to reduce GHGs and VMTs, but they are a service organization where direct service is needed so they cannot always telecommute (Interview with a City of San Jose representative, February 2013). These policies will be discussed in the next section.

A County representative cited the 2009 Climate Action Plan which lists telecommuting as a GHG reduction strategy (Interview with a County of Santa Clara representative, February 2013). The County did it to support a pilot in the ISD (Information Services Division) which helped to get telecommuting to be accepted politically. They chose telecommuting as a strategy because it made a lot of sense and people requested it in a commute survey they conducted (it was the number one choice) (Interview with a County of Santa Clara representative, February 2013). At the time, telecommuting was identified as a strong possibility for helping the County achieve GHG goals, but the culture was not supportive of it. Managers were worried that if an employee telecommutes, they will not be working. This issue of institutional and manager 
unwillingness is a common theme among the telecommuting literature reviewed and the interviews conducted.

The County's approach of investing in a pilot to provide measurable metrics and training was effective and visionary. Through their new CEMA union contract and telecommuting policy, they found that over a two month period, telecommuting allowed them to have VMT reductions of approximately 85,000 miles, NOx reductions of approximately 71,500 grams, VOC reductions of approximately 85,500 grams, CO2 reductions of approximately 83,000 pounds, and fuel and maintenance savings of approximately \$26,000 (Interview with a County of Santa Clara representative, February 2013). Their savings were measurable and impressive, but not only physical benefits were observed. Morale and productivity improved, sick days went down from 6.93 to 2.24 days a year, tasks were completed on time, and average response times increased (from thirty minutes before the pilot to ten minutes after the pilot) (Interview with a County of Santa Clara representative, February 2013). These benefits allowed the County to justify the program to the management and Board of Supervisors who are now in support of telecommuting as a realistic and impactful commute alternative. The County's policy will be further discussed in the following section.

\subsection{3: Telecommuting's Role in Reducing VMTs and GHGS}

The literature produced thirteen studies which assessed telecommuting's ability to reduce VMTs

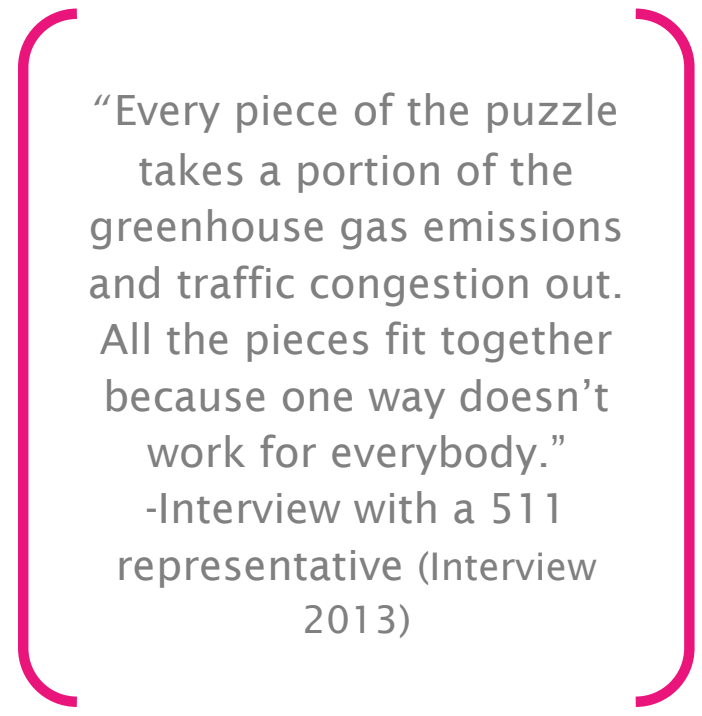
and GHGs through policies and travel reductions. Three studies argued that increased funding (i.e. federal subsidies, transit funding sources, or emissions credits trading) and incentives (i.e. company reimbursements or corporate tax breaks) for telecommuting could reduce VMTs (Difiglio and Fulton 2000, 664-666; Nelson 2004, 27; Nelson, Safirova and Walls 2007, 205). Difiglio and Fulton argue that if incentives are implemented for telecommuting, a 10 percent reduction in work trips can be achieved (665). Also, they note that telecommuting would continue to grow without government intervention, but incentives and other government help would increase success and implies that GHGs would continue to be reduced as a result of lowered VMTs (Difiglio and Fulton 2000, 665-666). The 511 representative provided insights into tangible ideas of VMT and GHG savings from telecommuting that 511 has collected during its lifetime as an organization. Observations have found that telecommuting provides a larger GHG reduction than public transit because transit still emits GHGs because some transit vehicles emit GHGs or the individual drives to the station (Interview with a 511 representative, February 2013). Also, telecommuting helps reduce GHGs by reducing the cold starts of engines and the first mile of drive which are the worst in terms of GHG emissions (Interview with a 511 representative, February 2013). It was also noted by 511 that Los Angeles and the Bay Area were 
recently tied in 2013 for the second highest congestion rates in the U.S. behind Washington D.C (Interview with a 511 representative, February 2013).

Four studies identified telecommuting's potential to reduce VMTs and GHGs. Koenig, Henderson and Mokhtarian (1996) found that telecommuting reduced personal VMTs and GHGs by 27 percent due to more frequent, but shorter trips (24-26). This was supported by Mokhtarian, Handy and Salomon's (1995) study which found that telecommuting reduced commute travel, but non-commute travel did increase slightly (292). Two studies noted that even with the increases in non-commute travel, the net VMT and GHG reductions were significant due to telecommuting participation (Mokhtarian, Handy and Salomon 1995, 294 \& 297; Nelson, Safirova and Walls 2007, 204). Nelson (2004) supported the previous arguments arguing that even though telecommuting is not the most effective reducer of GHGs, it can make a significant impact if implemented on a larger scale (i.e. congestion relief) (28-29). This study was supported by Nelson, Safirova and Walls (2007) who suggested that telecommuting is a realistic and beneficial strategy to reduce the pressure on existing roadways and make modest reductions in GHGs through VMT reductions (206).

By contrast, telecommuting's potential to decrease VMTs and GHGs may be overestimated. Five studies argue that due to decreased vehicle speeds, shifted commutes, longer average distances traveled by telecommuters due to residential relocation, and advances in cleaner vehicle technology reduce the actual net VMT and GHG savings, making telecommuting a modestly successful strategy (Koenig, Henderson and Mokhtarian 1996, 27; Mokhtarian, Handy and Salomon 1995, 292 \& 300-301; Nelson 2004, 26; Nelson, Safirova and Walls 2007, 201). This conclusion is supported by Koenig, Henderson and Mokhtarian (1996) who noted that the VMT reductions from increased telecommuting can lead to a net decrease of emissions and traffic congestion (28).

The interviews with Cisco and the County mentioned the potential for telecommuting to reduce GHGs by encouraging "hoteling" which reduces the need for employers to provide each employee with a cubicle. Hoteling allows the employer to rent office space when the employee is in the office which may only be two or three days a week (Interview with a Cisco Systems representative, February 2013; Interview with a County of Santa Clara representative, February 2013). Cisco has experienced that all of their buildings except the headquarters building are practically empty on Mondays and Fridays and are usually only at 50 percent capacity during the week because of the large percentage of employees that take advantage of telecommuting (Interview with a Cisco Systems representative, February 2013). The other interviewees did not know if telecommuting effectively reduces VMTs or GHGs significantly for their organizations, but theorized that some benefit was possible. This may represent a knowledge gap among organizations or their employees concerning telecommuting as a viable GHG and VMT reduction tool. When the interviewees were initially asked about telecommuting, their instinctive responses were regarding its positive effects on work-life balance and increased productivity, not GHG and VMT savings. 


\section{5: Themes Present in Only the Literature}

\subsection{1: Effective Telecommuting Policies and Programs}

Research suggests that tax incentives and other programs should be incorporated into telecommuting policies to increase their success. Financial incentives (specifically tax incentives or reimbursement programs) may be used to support the adoption of telecommuting because they are seen as "low-hanging fruit" being easy to implement as initial strategies to meet AB32 requirements (Shaheen, Benjamin-Chung, Allen, and Howe-Steiger 2009, 36 and 79). This is evident as eight U.S. states (California, Oregon, New Jersey, Maryland, Washington, Virginia, Arizona, and Georgia) have formal telecommuting policies which encourage employers (both public and private) to promote telecommuting which in theory will help them advance their GHG reduction goals (Gardiner, Lovaas and Horner 2011, 3; Bhatt, Peppard and Potts 2010, 42). However, even though many tax incentives were discussed in the literature, the articles did not evaluate the success of the tax incentives at increasing telecommuting. It should be noted that the incentives mentioned here are different than those mentioned in the previous section as these incentives are specifically for the employer, not the employee.

Another interesting issue not addressed by the interviews was the possibility of telecommuting increasing decentralization. Lyons (2002) suggests that a way to prevent residential relocation as a result of increased telecommuting is to draft formal policies that provide fiscal incentives for the employer or employee to live closer to work (catchment area policy) (344). This could prevent urban sprawl and decrease VMTs (Lyons 2002,344). This is supported by three studies which suggest that future transport policy should include policies that promote telecommuting and flexible work schedules in order to reduce road congestion (Stopher 2004, 129; Bhatt, Peppard and Potts 2010, 12; Hartgen, Fields, Scott and San Jose 2011, 56). Further support is provided by Hartgen, Fields, Scott and San Jose's (2011) study which found that the net benefit of telecommuting is $\$ 122$ annually per telecommuter, demonstrating that the benefits of telecommuting are greater than the costs (Hartgen, Fields, Scott and San Jose 2011, 56). By contrast, telecommuting programs cost employers $\$ 420 /$ telecommuter annually (Hartgen, Fields, Scott and San Jose 2011,56). The authors concluded that the public sector does not benefit from telecommuters due to lost fuel tax revenues (Hartgen, Fields, Scott and San Jose 2011, 56). Furthermore, telecommuting is only directly beneficial to the telecommuter; indirect social benefits include increased employee satisfaction and reduced congestion, but they do not necessarily balance the financial burden of the companies (Hartgen, Fields, Scott and San Jose 2011, 56). Large upfront costs for telecommuting programs include training of the managers and employees and long-term support; however, employees experienced increased flexibility, freedom and less personal travel (Hartgen, Fields, Scott and San Jose 2011, 56).

\subsection{2: Telecommuting and Trip Substitution}

Six studies argue that telecommuting acts as a substitution for physical travel. Coroma, Hilty and Birtel (2011) found that telecommuting could be used to reduce international conference VMTs and GHGs by hosting the conference in two locations instead of one, resulting in a 50 
percent reduction in $\mathrm{CO}_{2}$ emissions after accounting for rebound affects (370). This finding was supported by Hjorthol (2002) arguing that even though travel was not completely substituted by telecommuting, large reductions in commute travel can be gained from telecommuting participation (449-452). Hamer, Kroes and Van Ooststroom (1991) found that telecommuting resulted in a 17 percent decrease in trips for telecommuters as well as an average decrease in non-commute travel of 14 percent (375-376). Helminen and Ristimaki (2007) came to a similar conclusion that telecommuting directly substitutes 0.7 percent of commuting trips (338) and L.M. Hilty et al. (2006) concluded that increased usage of ICTs can increase telecommuting and change travel patterns resulting in a 6-8 percent reduction in passenger transport via car (1626). Another interesting study by Andrey, Burns and Doherty (2004) supported the substitution idea stating that telecommuting can be an enabler of travel behavior change as their study found that individuals could substitute physical travel for telecommunications technologies (266-268).

These five studies contradict the substitution findings, arguing that telecommuting has a complementary relationship with travel resulting in trip generation. Mokhtarian and Meenakshisundaram (1999) and Tonn and Hemrick (2004) found that email or telecommunications usage generated trips due to increased connectivity among individuals (47; 275-276). The authors speculated that the complementary relationship was due to a broader scope of variables included in the model instead of the typical "narrowly focused, unidirectional analyses" looking at only one aspect of telecommunications and its relationship to travel (i.e. telecommuting) instead of multiple telecommunications strategies and the resulting travel influences (Mokhtarian and Meenakshisundaram 1999, 49-50). A supporting study found that devices like home computers increased the flexibility of work activities, but did not reduce actual physical travel; additional trips outside of commute trips were usually recreational (Hjorthol 2002, 451). Black (1996) argued that many government and company telecommuting policies assume that telecommuting would not induce trips, but would rather replace the commute which he argues is unrealistic (156). Lastly, Audirac (2002) argues that telecommuting is found to only reduce 1 percent of total household VMT due to the ability for telecommunications to stimulate urban sprawl and increased travel (216).

In sum, the research suggests that no consensus exists regarding if telecommuting reduces VMTs and GHGs, by how much it can reduce VMTs and GHGs, or if the relationship between telecommuting and travel is substitution or complementary. These findings do not conclusively support the hypothesis that telecommuting can produce VMT and GHG reductions nor that telecommunication's relationship with travel is substitution. The interviews did not provide further insights to these areas of disagreement leaving these topics as areas of further research.

\section{6: Themes Present Only in the Interviews}

The following themes present in the interviews, but not the literature, are discussed below. These issues may not have been discussed in the literature due to the literature review's narrow scope of GHG and VMT reductions and telecommuting. The interviewees' thoughts are still valuable and can inform the recommendations of this report. 


\section{Work-life Balance}

The Partners Mortgage representative stated that most people telecommuting for work-life balance reasons, like familial obligations.

\section{Informal Policy in Place or No Policy}

Shenick does not have a formal telecommuting policy and it is allowed on a case-by-case basis. Somas Mayfair does not currently have a telecommuting policy, but they are interested in starting one. The Somas Mayfair representative stated that people are requesting it at initial hire and it will be written into their contracts (change of relationship form). Partners Mortgage has an informal telecommuting policy with not written formal agreement. The arrangement is usually documented in an email between the employee and supervisor.

\section{Data Gap}

The City of San Jose representative mentioned that a data gap was present as the City does not formally collect VMT and GHG data specifically concerning telecommuting. Also, no formal study has been conducted to assess the effectiveness of telecommuting at meeting GHG and VMT goals. This suggests a data gap exists regarding telecommuting's ability to meet GHG or VMT goals. If the data are not being collected, then a quantitative analysis of effectiveness cannot be easily run. Without hard numbers to prove whether or not telecommuting is effective in some organizations, other companies may be less willing to try telecommuting as a strategy to meet GHG reduction goals or increase the work-life balance for their employees.

\section{Manager Discretion}

Juniper Networks, Shenick Network Systems, NOAA, Cisco Systems, Somas Mayfair, the City of San Jose, and Partners Mortgage representatives all stated that telecommuting participation was at the manager's discretion and was department specific, even if a formal telecommuting policy existed.

"In the age of a global market, time and distance separate people and workspaces. Cisco has long recognized that telecommuting and collaborative technologies are effective in breaking down separation barriers and enabling the transition to the borderless enterprise. -Rami Mazid, vice president, Global Client Services and Operations, Cisco (Cisco Systems Telecommuting Policy)

\section{OSHA standards}

The Juniper representative specifically mentioned that Juniper requires the employee to have an ergonomic office following OSHA standards.

\section{Unsupportive Culture and Political Acceptance}

Santa Clara County's 2009 Climate Action Plan lists telecommuting as a strategy due to its popularity among employees (it was being requested as a benefit), but the culture was not 
supportive of it. In order to gain support for telecommuting from specifically managers who were afraid their employees would not be working when at home, the County's Information Services Department (ISD) ran a very successful pilot program. Due to the ISD pilot program's success and the success of a few other pilots, telecommuting is gaining political acceptance at the County.

\section{Manager Perceptions and Trust}

The Cisco representative stated that there is something to be said for those who interact in person with colleagues, like reading body signals. The County representatives and the 511 representative all stated that managers' negative perceptions of telecommuting were somewhat if not completely alleviated after attending mandatory telecommuting trainings. These trainings are designed to dispel the myths surrounding telecommuting and ensure that the manager and employee have a clear understanding of what telecommuting is, what it is not, and how to use it effectively. The Shenick Networks representative said that trust was a large part of whether or not an employee would be allowed to telecommute. If the manager did not trust the employee to maintain their productivity and quality of work, telecommuting would not be allowed.

\section{Facilities Costs Savings}

The Cisco representative shared that Cisco is now selling off some of their buildings because of programs like telecommuting. Typically no more than 50 percent of the employees are in the office at a time and the offices are empty on Mondays and Fridays. A County representative also shared that the County is considering telecommuting on a larger scale because of the potential facilities costs savings.

\section{Collaborative Workspaces}

The Cisco representative works in a building with a remote worker environment with lower cubicle heights which encourages collaboration.

\section{Guilt}

The Cisco representative mentioned that dealing with guilt when learning to work from home was an issue. This is because the employee will have to multi-task with both personal and work issues. It is unrealistic to think that employees work every single minute that they are in the office, so the same must apply at home. The interviewee's boss did not care what the employee was doing every minute just as long as the employee completes the tasks on time and well.

\section{Changes in Communication}

At Cisco, not all the employees rely on in-person communication, but prefer "ping," a type of instant messenger, or email. The Partners Mortgage representative found that while she was forced to work at home due to an illness, she was still able to work effectively and maintain valuable contact with her manager and coworkers. It put into perspective that telecommuting does not necessarily limit the interactions among employees if managed well. She also found that she did not see her manager in-person at the office often, but when she was telecommuting regularly, she would talk to him more frequently on the phone. 


\section{Sometimes In-office is Better}

The Cisco representative observed that some people do not enjoy having work in their homes as it makes life more complicated. Also, negotiations may be more easily initiated during office hallway run-ins rather than through email or phone calls. In essence, one could catch a person in a metaphorical "drive-by" encounter which cannot be done when one is telecommuting. As was recently suggested by Yahoo, telecommuting may inhibit hallway drive-bys that the Cisco interviewee mentioned. While telecommuting may limit the ability for in-person chance encounters, the research suggests that it does more good than harm. A profound number of studies suggest that telecommuting not only increases work-life balance and productivity for employees, it also promotes a more global culture through the usage of mobile technologies. Where we work may no longer be as important as how we work. If companies take the Yahoo approach, then they theoretically cannot have remote employees all around the U.S. and the world. This would limit their ability to attract the most qualified, diverse, and talented employees due to this limitation. The literature argued that working from home on a part-time basis was ideal as it allowed an employee to have scheduled uninterrupted time where they can focus on tasks and produce results. It is no accident that telecommuting research proves that when employees telecommute, productivity not only meets but exceeds expectations and current in-office levels. Will Yahoo experience decreased employee morale as work-life balance fades and lower productivity? Will banning telecommuting and promoting togetherness really increase the speed and quality of their work? Only time will tell.

\section{Increased Morale}

All the interviewees implied that increased morale was a significant benefit of telecommuting due to increased flexibility and better work-life balance.

\section{Time-series Analysis}

The County, with the help of 511, ran a time-series analysis of telecommuting effectiveness. This before and after study proved effective as they were able to measure the changes that occurred among one group of people due to telecommuting. This type of study would prove useful to others considering a telecommuting pilot as it would provide quantifiable evidence of telecommuting's effectiveness.

\section{Fewer Sick Days}

511, the County, Somas Mayfair, and Partners Mortgage all commented on the ability for

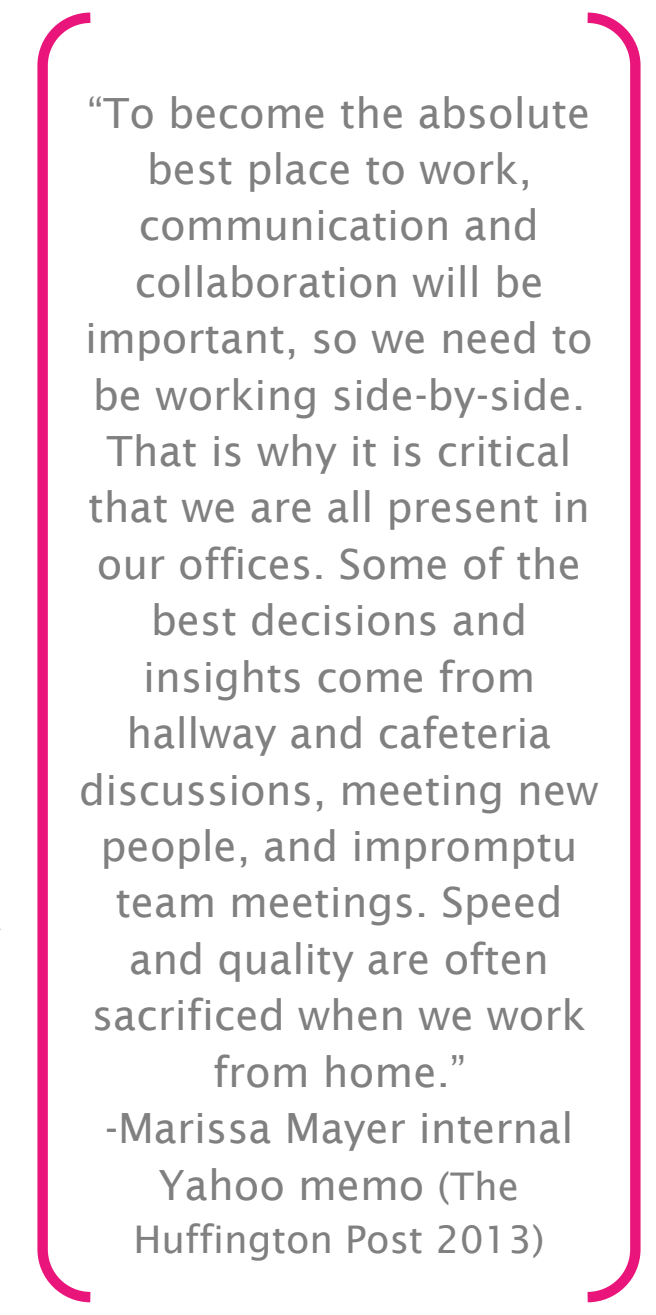


telecommuting to reduce the number of sick days among employees. A County representative mentioned that sick days went down from roughly seven a year to two days a year. The 511 representative said that if an individual is too sick to go to work, but not too sick to not work, then telecommuting provides an opportunity to not take sick leave and maintain productivity.

\section{Allows for Quiet Workspace}

The 511 and Somas Mayfair representatives commented that telecommuting provides relief for employees from constant interruptions common in an office environment. The home environment can be ideal for provide a quiet workspace designed for reading, writing, editing, and other intensive tasks.

\section{Establish Rituals}

The 511 representative discussed how important it is to establish rituals to make the telecommuting workday serious. For example, an employee could get up and put on his badge and work from home. When his children come home from school they would see that their father was wearing his badge and that meant he was working and should not be disturbed. Telecommuters must utilize rituals and make sure to take breaks and lunch. An employee may also walk around the block in the morning to simulate the missed commute.

\section{Policy Not Publically Available}

Some companies like Apple, Cisco, and Juniper Networks do not have their policies publically available. In the case of Apple, their policy was considered confidential, while Cisco and Juniper store the file on their interoffice web portal.

\section{Computer Skills/Literacy}

The Somas Mayfair representative mentioned that some of the staff are not as computer literate as others, making the transition to telecommuting difficult. While some aspects of telecommuting may be heavily reliant on computers, not all telecommuting has to be done on a computer. For example, an employee can take reports home to edit and read in hardcopy formats or draft new documents with paper and pen. Telecommuting is about using at minimum a phone to maintain contact with the office while enjoying the flexibility of staying at home to concentrate on a task. 


\section{4: Synthesis, Discussion, and Recommendations for Telecommuting Adoption and Success}

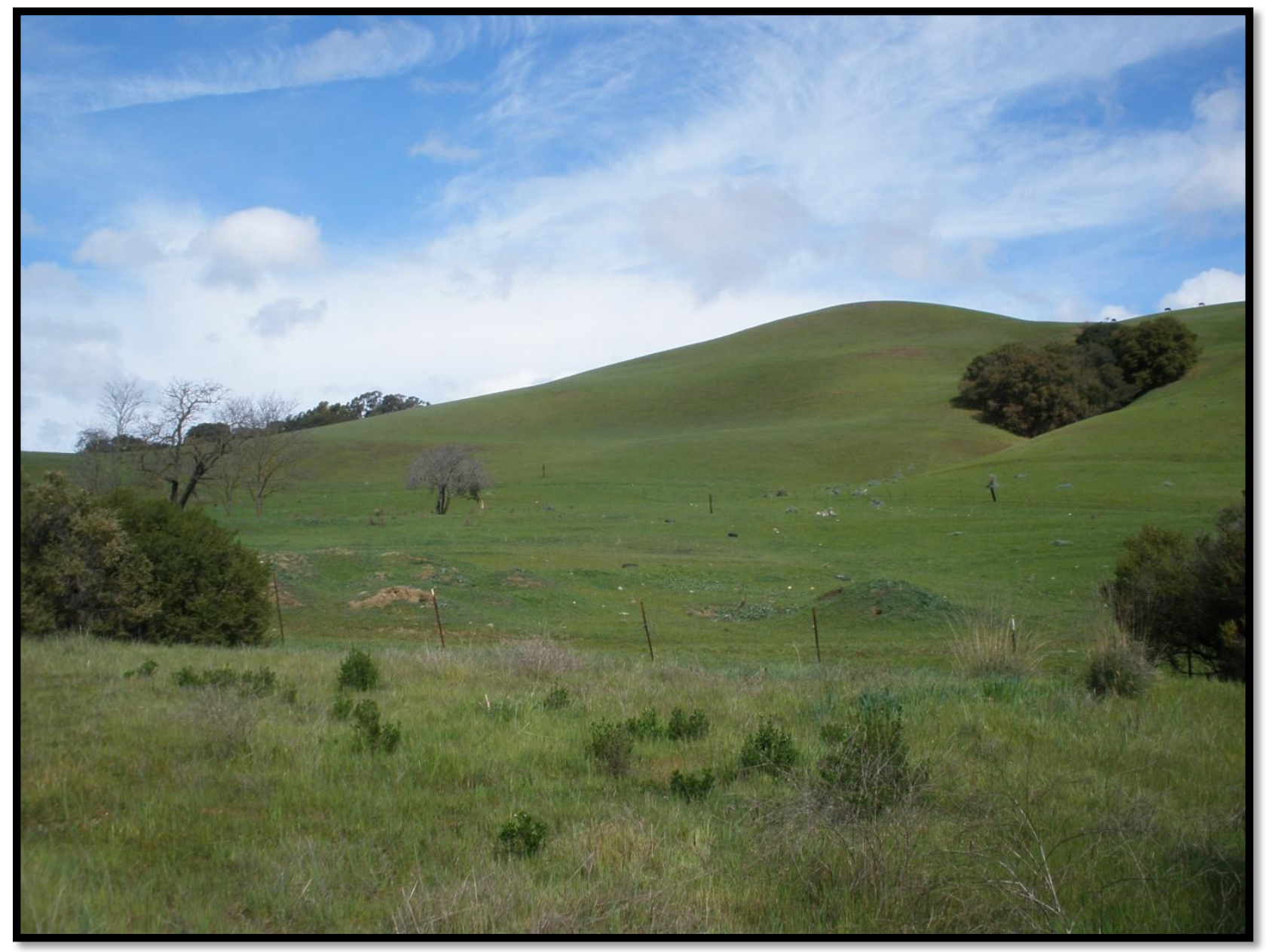

Figure 8: East Foothills in San Jose

\section{1: Synthesis of Telecommuting Policies}

\subsection{1: Telecommuting Definition}

It was important to first determine how the different employers defined telecommuting as the definition would determine how it would be applied, potentially affecting telecommuting's effectiveness. All of the employers define telecommuting in their policies as working away from the central office either at home, a hotel, an airport, a telecommuting center, or in the car. The most common definitions in government policies stated that they promoted home working instead of satellite office working (in locations like a Starbucks or telecommuting center) because working from home theoretically eliminates the commute trip. However, it is possible that the home telecommuter could go out in their car every telecommuting day to buy a latte and still produce a cold start and GHG emissions, but their overall VMTs should be lower than 
if they drove to work. Please see Appendix B: Synthesis of Telecommuting Policies Table 6 for the full list of definitions.

It should be noted that San Jose lists telecommuting in its general plan, but it is inconspicuous due to an ambiguous name (work from home). This may be seen as not being transparent enough. This calls into question the need for a standard terminology and definition. If telecommuting is routinely referred to by one name and the definitions remain consistent, policies and programs can be more easily compared.

\subsection{2: Telecommuting Eligibility}

Telecommuting eligibility was analyzed by looking at common eligibility criteria, different criteria, and innovative criteria. Table 7 in Appendix B: Synthesis of Telecommuting Policies has a full list of the eligibility criteria.

Common eligibility criteria were manager discretion, appropriate job tasks, and a good performance rating of the employee. Employees typically have to be self-motivated, have good time-management skills, permanent employees, not be on probationary status, not have any disciplinary issues on file, must maintain productivity, and require minimum in-person contact.

Different eligibility criteria included being in a specific union represented class, most work must be computer based, and managers and employees must attend telecommuting training classes. Both being in a union represented class and attending mandatory telecommuting trainings were considered innovative approaches to defining eligibility. Having the telecommuting policy written into the union contract legally specifies who is covered under telecommuting, and an eligible employee cannot be prevented from participating if a manager is being unreasonable. Requiring training for both the employees and managers was repeatedly referred to by County of Santa Clara employees and the 511 representative during the interviews as a necessary step to ensure a successful telecommuting program with higher participation rates, increased productivity, and happier employees.

\subsection{3: Benefits of Telecommuting}

Telecommuting policy benefits were analyzed by looking at common benefits mentioned, different benefits, and innovative benefits. Table 8 in Appendix B: Synthesis of Telecommuting Policies has a full list of the benefits.

\section{Common telecommuting benefits include:}

- Increased productivity

- Environmental benefits (GHG reductions/air pollution prevention)

- Reduced traffic congestion

- Improved quality of life

- Better work-life balance

- Office and facility cost savings

- Increased employee effectiveness 
- Increased employee morale

- Decreased energy usage

- Increased creativity

- Stress reductions

- Feelings of liberation

- Reducing travel

- Meeting federal, state or regional standards (AB32 and SB375)

- Attracting and retaining employees

- Reduced absenteeism

- Reduced travel expenses

\section{Different telecommuting benefits include:}

- Continued service during emergencies (natural and man-made)

- Increased ADA compliance (allowing access to jobs for disabled individuals)

- Effective use of staff and resources

- "Hoteling"

- Decreased sick leave

- Decreased medical costs

- Reduced parking requirements

- Decreased employee turnover

- Decreased highway costs

- Employees were specifically requesting telecommuting, making it a popular commuting option

- Employees are happier and healthier

- Mutually beneficial for employee and manager

- Reduction of peak-hour trips

- Reduction of automobile cold starts

Innovative telecommuting benefits include many ideas from the different categories. Continued service during emergencies was mentioned by a few government policies and speaks volumes about the fragile nature of our infrastructure. If a bridge were to collapse or a blizzard were to blanket a city in snow, telecommuting could provide an option for employees to work without visiting the office. Increased Americans with Disabilities Act (ADA) compliance was also mentioned by a few policies and implies that telecommuting is one more way to make jobs that utilize a computer or phone more accessible to those with limited mobility. Telecommuting was listed as reducing sick leave and medical costs perhaps through allowing greater work-life balance. This may mean that employees are taking more time to enjoy life with their families and taking better care of themselves.

Reducing parking requirements and office space is a large GHG reductions benefit as less energy has to be used by buildings and less land is covered in large office parks and the associated sprawling parking lots. Theoretically highway costs would be reduced as fewer people are driving on them when telecommuting is utilized. Using telecommuting as a reward for reliable employees is innovative as it provides a non-monetary bonus which can affect many 
facets of the employee's life. They may have more time to be with their children or partake in an exercise class if they do not have to commute to work every day. If employees are not starting their cars due to telecommuting, then the car does not have a cold start for that day. Cold starts produce the most pollution when driving a car and if these can be reduced, GHG levels will be reduced. Lastly, telecommuting being part of a union contract is beneficial because, in the case of the County of Santa Clara, they require that managers and employees train to telecommute, dispel myths about telecommuting, and provide the dos and don'ts of how the program works. This legal document helps ensure that telecommuting is not abused and that it effectively helps employees maintain work-life balance and reduce their GHG emissions.

\subsection{4: Barriers Affecting Telecommuting Success}

Telecommuting policy issues or barriers were analyzed by looking at what were common issues and different issues mentioned. Table 9 in Appendix B: Synthesis of Telecommuting Policies has a full list of the issues.

Common issues included manager resistance, strong formal policies needed for telecommuting to work, employee must maintain their productivity, employee must not have a job with lots of face-to-face interactions, training and education are needed, and telecommuting is not meant to be a substitute for child or elderly care. Issues that differed include the needs of Generation X are more focused on work-life balance, zoning ordinances may need to be addressed to allow home telecommuting, information security, management techniques must change with the changing work trends (global and mobile), employee accountability is sometimes difficult to track, and workers' compensation issues. All of these issues, both common and different, must be considered by employers wishing to implement a telecommuting policy. Telecommuting is not suited to every job or every person, and it is a hope of the author that this paper can help shed light on what works, what does not, and how telecommuting can help an organization meet their work-life balance and GHG goals.

\section{2: Discussion of Findings from Literature, Interviews and Policies}

\subsection{1: Common Findings from Literature, Interviews and Policies}

Telecommuting may be a contributor to urban sprawl and decentralization as it may allow employees to live farther from work because they do not have to commute five days per week. This issue is a big concern for San Jose employers as many are most likely to live in typical San Jose suburban neighborhoods. It should also be noted that the literature made a strong argument that cars are a sign of wealth and prosperity in the United States. When people choose to drive a car to work, they may be making a statement about their success whether or not it is conscious. To get people out of their cars would require a cultural shift where owning and driving a car would not be indicative of success and prosperity.

Telecommuting is a moderately successful tool for reducing traffic congestion. As is similar with using telecommuting to reduce GHGs, telecommuting is just one of many strategies that contribute to the overall reduction in traffic congestion. 
Telecommuting was cited as an effective reducer of office space and facility needs in the literature, interviews, and policies. A reduction in office space and facilities provided the company with cost savings and GHG emissions reductions.

Work-life balance and flexibility are major motivations behind telecommuting. The interviews, literature, and policies cited that employees wanted more time with their families and more time to navigate their hectic lives (for example, having to wait for the cable guy).

Telecommuting can be a flexible tool that employees utilize to ensure they can meet their work objectives and deadlines without sacrificing their familial or personal obligations. It should be noted that telecommuting is not for every job or every individual. Anyone interested in telecommuting should ensure that their job tasks are suited for mobile work and that they are able to work effectively in an environment where they are more isolated and independent.

Meeting government regulations was a huge motivator for companies to embrace telecommuting as a GHG reduction strategy because it is low to no cost and offers a wide range of environmental, financial, and personal benefits. Many of the companies interviewed and the policies reviewed stated that they found telecommuting to produce GHG emissions reductions that warranted a continuation of the program. It should be kept in mind that telecommuting is just one strategy that should be used in conjunction with others to reduce an employer's GHG emissions.

\subsection{2: Different and Innovative Findings from Literature, Interviews and Policies}

The government organizations interviewed suggested that formal telecommuting policies were the best way to encourage telecommuting participation and effectiveness. Due to this, most of the government organizations included in this report already had some sort of formal telecommuting policy, but they all varied based on quality and components. The literature supported the finding from the interviews that formal telecommuting policies ensure the best success rate. Formal policies detail the rules and regulations involved with telecommuting which protect the participating agency and employees. A particularly innovative approach was implemented by 511 and the County of Santa Clara where they integrated their telecommuting policy into their County Employees Management Association (CEMA) union contract. This ensured that the telecommuting policy had "teeth" so participation was more likely because participation was not left up to just manager discretion, but also union rules.

The government agencies and some of the companies interviewed stressed the importance of training employees and managers prior to telecommuting participation. Training helped dispel the myths surrounding telecommuting, helped managers with different ways of handling a mobile workforce, and prepared employees for working without direct supervision. These measures were shown in the literature to improve success rates and maintain or increase productivity, which allowed for employers and employees to reap the benefits of telecommuting. Issues about training surrounded the extra costs of staff preparation and 
training sessions. Organizations like 511 offer help to implement policies and run trainings which may not be very cost prohibitive.

Both the interviews and policies mentioned the importance of the "changing workplace" which is shifting into a more global workspace and that managers and employees must adapt the way they work to work within the new system. These interviews and policies suggested that strategies like "hoteling" or more collaborative workspaces, with larger open seating and large tables for collaboration, are the future for the work place as industries continue to become more global.

\section{3: Recommendations for Telecommuting Adoption and Success}

Drawing from the literature, interviews, and policy review, recommendations will be made for private sector employers and public sector employers. It should be noted that public sector employers like government agencies typically have more employees whose jobs are not suitable for telecommuting. For example, many government jobs require direct in-person service which cannot be completed at home. Some jobs, whether in the public or private sector, are not suitable for telecommuting because they require in-field work.

\subsection{1: Public Sector Employers}

The City of San Jose should update its 2040 General Plan Transportation Demand Management Action TR-7.2 to include telecommuting as a specific type of flexible work schedule strategy to address the goal of reducing VMTs within the city. The current text for Action TR-7.2 is:

“Update and enhance the existing TDM program for City of San José employees. This program may include the expansion of transit pass subsidies, free shuttle service, preferential carpool parking, ridesharing, flexible work schedules, parking pricing, carsharing, and other measures" (City of San Jose General Plan 2011, 49).

Even though general plans are not usually specific, the terminology can be updated as the general plan is the foundational governing document of the City itself, outlining the goals, policies, and actions the City has considered suitable. San Jose employers and other metropolitan regions or governments may look to San Jose as an example of excellent TDM strategies, and it would be influential if the City were to include telecommuting among those strategies. It is particularly important to mention that of the strategies mentioned under this action item, including transit pass subsidies, free shuttle service, carpool parking, parking pricing, car-sharing, rideshare, and flexible work schedules, none of these strategies except potentially the transit pass subsidies and the flexible work schedules gets people out of their cars. If the goal is to reduce VMTs, the City should specifically include telecommuting as it has the potential to eliminate car trips for an entire workday. Public employers should view telecommuting as one strategy to reduce GHGs in order to meet federal and state regulations. These regulations may include AB 32 and SB 375. 


\subsection{2: Private Sector Employers}

The City or County could require private sector companies of over a certain number of employees (the threshold must be investigated further in order to determine the appropriate number, but could be over five hundred or one-thousand employees) to make their VMT and GHG data publicly available. These data would also be useful to private employers who want the most cost-effective strategies to implement while making their employees happy. A limitation in this research project is the difficulty the author encountered when attempting to gather this data. If the data were available, then other employers, the government, or third parties could conduct "back of the envelope" calculations concerning the current VMT and GHG reduction needs and potentials. This information could prove useful in the event that a company or the City want to evaluate whether or not to implement a telecommuting program, start a TDM strategy, or start a telecommuting pilot program.

\subsection{3: Private and Public Sector Employers}

Employers should consider contacting their union about integrating telecommuting into their union contract. 511 is an excellent resource for unions and companies who want to draft a telecommuting policy, start a pilot program, or track their VMT and GHG savings.

Employers should consider telecommuting as an emergency backup strategy to maintain company operations during a natural disaster or other emergency. The federal government provides excellent examples of using telecommuting as an emergency preparedness strategy.

Telecommuting should be considered not only for its GHG and VMT reduction potential, but for its work-life balance potential. Employees who have better balance between their work and personal lives are shown to be more productive.

The research indicated that one-fifth of all the commercial energy in the U.S. for office complexes is used to power air conditioners, lighting, and office equipment. Perhaps a policy at the public and private sector level can address or enforce a ratio of workers that must occupy an office building for it to remain open. If this ratio is not met, the company can close down the building and save energy and money. By increasing telecommuting, companies can reduce their needs for office space and save significant amounts of money.

\subsection{4: Opportunities for Further Research}

A future study would benefit from the inclusion of more policies from private employers. This study was unable to secure many private policies due to issues of confidentiality, but perhaps further research could uncover private employers who would share their policies.

It would be interesting if a future research project could explore the effectiveness of telecommuting at reducing VMTs and GHGs through a quantitative analysis. The study could involve the collection of VMT and GHG data from both public and private employers, perhaps through online trip diaries. These data can be put into available GHG calculators which would provide quantifiable results detailing the effectiveness of telecommuting at reducing GHGs. 
One example of a calculator is the National Institutes of Health's Teleworking Cost and Environmental Saving Estimate calculator as seen in Figure 9. This tool is free and available for use on their website at traffic.nih.gov and a screenshot is on the following page. Like many of the other free online calculators, this tool requires basic information about the organization and its employees' habits including the number of days they telecommute on average, the distance in miles of a one-way commute, the type of vehicle they drive, the current price of gas, and the number of employees that engage in telecommuting. These values are used to calculate the annual cost savings in time and for vehicles as well as the annual reduction of GHGs in pounds. These calculators provide quick and simple ways for a company to determine if telecommuting can have an effect on the company's VMT and GHG goals as well as telecommuting's potential to provide the company with cost savings.

More in-depth and precise calculators are available for download online for government agencies and companies. These calculators can indicate exactly how much of a particular GHG the employer can save or home much office space can be eliminated based on different rates of telecommuting. Examples of these calculators include:

- COMMUTER model: This is from the EPA which calculates telecommuting's impact on VMT, resulting in the number of trips eliminated. This is important because it develops a tangible number of trips that can be actually reduced when different percentages of people actively telecommute within a company or city. Information about this model can be found at http:/ / www.epa.gov/oms/stateresources/policy/transp/commuter/420b05017.pdf.

- Urbemis GHG emissions calculator: This calculator can estimate the impact of VMT on GHGs. It can be accessed at http:/ / www.urbemis.com/software/download.html. 


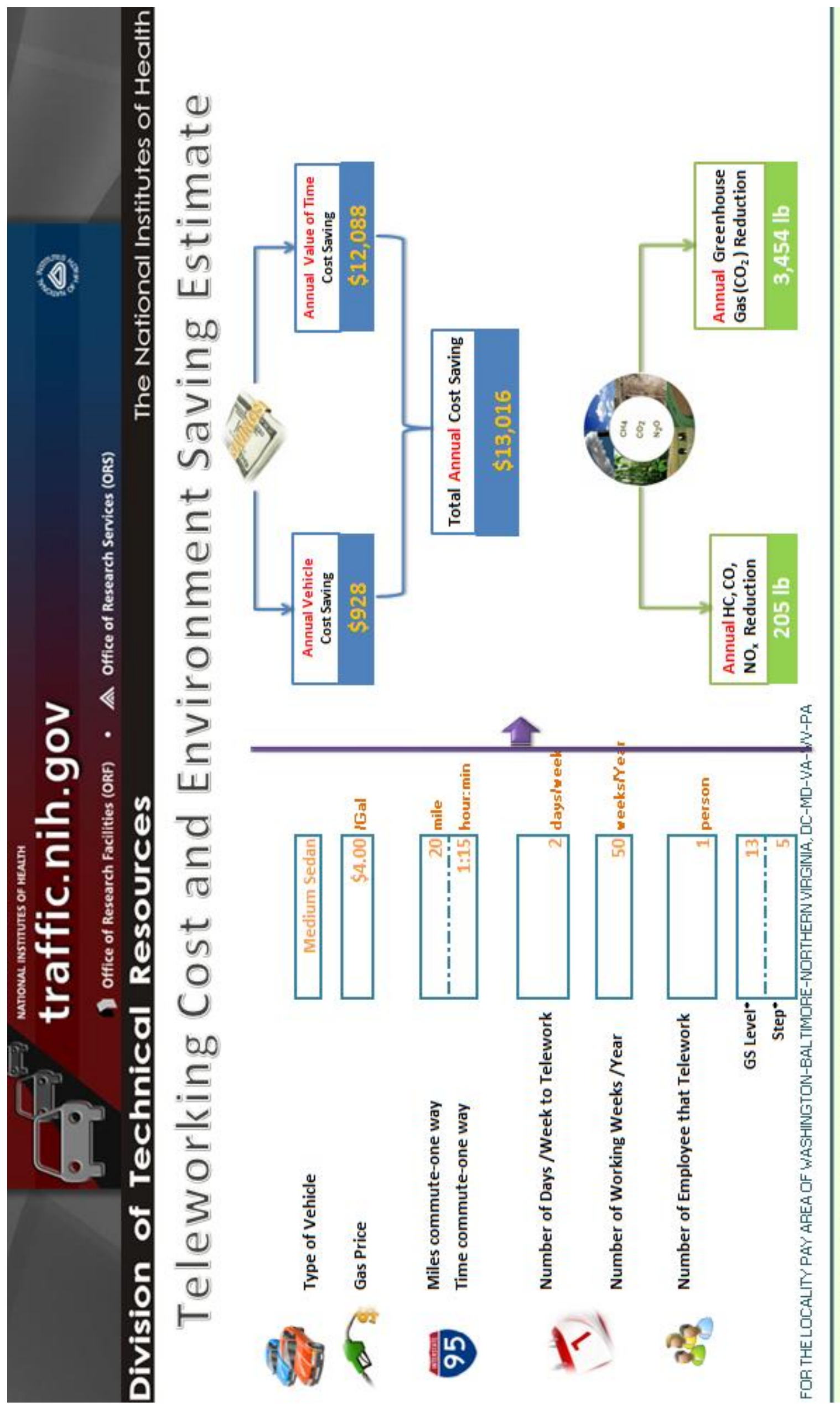

(v)

(1)

㫪
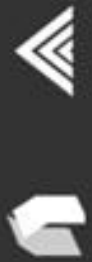

Figure 9: NHI's Teleworking Cost and Environmental Saving Estimate Calculator 
This page intentionally left blank. 


\section{Reference List}

36 Commuting Solutions. 2012. Telework: A modern luxury. 36 Commuting Solutions.

http:/ /36commutingsolutions.org/commuting-us-36/commute-options/telework/

Alpine Access. Telework Case Study.

http:/ / www3.drcog.org/ridearrangers/content/documents / Casepercent20Studiesperc ent20Alpinepercent20Access.pdf.

Andrey, Jean C., Kyle R. Burns, and Sean T. Doherty. 2004. Toward sustainable transportation:

Exploring transportation decision making in teleworking households in a mid-sized Canadian city. Canadian Journal of Urban Research 1, no.2: 257-277.

Atkyns, Robert, Michele Blazek, Joseph Roitz, and AT\&T. 2002. Measurement of environmental impacts of telework adoption amidst change in complex organizations: AT\&T survey methodology and results. Resources, Conservation and Recycling 36, no. 3: 267-285.

Audirac, Ivonne. 2002. Information technology and urban form. Journal of Planning Literature 17, no. 2: 212-226.

Bailey, D. E. \& Kurland, N. B. 2002. A review of telework research: Findings, new direction, and lessons for the study of modern work. Journal of Organizational Behavior 23: 383-400.

Bhatt, Neha, Colin Peppard, and Stephanie Potts. 2010. Getting back on track: Aligning state transportation policy with climate change goals. Smart Growth America and Natural Resources Defense Council.

Black, William R. 1996. Sustainable transportation: A US perspective. Journal of Transport Geography 4, no. 3: 151-159.

Boarnet, Marlon G. Planning, climate change, and transportation: Thoughts on policy analysis. Transportation Research Part A: Policy and Practice 44, no. 8: 587-595.

Bose, Ranjit and Xin Luo. 2011. Integrative framework for assessing firms' potential to undertake green IT initiatives via virtualization - A theoretical perspective. The Journal of Strategic Information Systems 20, no. 1: 38-54.

Brewer, Ann M. 1998. Work design, flexible work arrangements and travel behavior: Policy implications. Institute of Transport Studies 5: 93-101.

Brown, Colby, Prashant Balepur, and Patricia Mokhtarian. 2005. Communication chains: A methodology for assessing the effects of the Internet on communication and travel. Journal of Urban Technology 12, no. 1: 71-98.

Bryant, S. 2008. Wired to the world, chained to the home: Telework in daily life. Canadian Journal Of Communication 33, no.1: 135-136. 
Caldow, Janet. 2009. Working outside the box: A study on the growing momentum in telework. Institute for Electronic Government, IBM Corporation.

California Department of General Services. 2009. About statewide telework (telecommuting). http://www.dgs.ca.gov/dgs/ProgramsServices/telework.aspx.

California Department of General Services. 2010. 2010 Telework program policy and procedures April.

http:/ / www.documents.dgs.ca.gov/dgs/pio/telework/2010percent20Teleworkpercent 20Programpercent20Policypercent20and percent20Procedurespercent20April.doc

Choo, Sangho and Patricia L. Mokhtarian. 2007. Telecommunications and travel demand and supply: Aggregate structural equation models for the US. Transportation Research Part A: Policy and Practice 41, no. 1 (January): 4-18.

Choo, Sangho, Patricia L. Mokhtarian, and Ilan Salomon. 2005. Does telecommuting reduce vehicle-miles traveled? An aggregate time series analysis for the U.S. Transportation 32, no. 1: 37-64.

Cisco Systems. 2009. Cisco study finds telecommuting significantly increases employee productivity, work-life flexibility and job satisfaction. The Network.

http://newsroom.cisco.com/dlls/2009/prod_062609.html.

Cisco Systems. 2011. Flexible Work Practices Overview. (confidential).

Cisco Systems. 2011. Managed Teleworker Service. (confidential).

Cisco Systems. Telecommuting policy (confidential).

City and County of San Francisco. 2001. Work-life policies and practices survey report. http://s3.amazonaws.com/zanran_storage/www.sfgov.org/ContentPages/7477897.pd f.

City of Los Angeles. 2008. Telemanager's handbook.

http://per.lacity.org/bens/TelemanagerHandbook.pdf.

City of San Diego Environmental Services Department. 2005. San Diego climate protection action plan.

City of San Francisco. 2011. Climate action strategy for San Francisco's transportation system. http:/ / www.sfmta.com/cms/cmta/documents/4-19-11item13CAS-citywide.pdf.

City of San Francisco Department of Human Resources. 2005. Pilot telecommuting policy and program: Program guidelines and participation packet, by Philip A. Ginsburg. 
City of San Jose. 2011. Envision San Jose 2040 general plan.

http://www.sanjoseca.gov/planning/gp_update/FinalText/EST2040GeneralPlan_12-12011.pdf.

City of San Jose. 2007. Green vision goals. http:/ / www.sanjoseca.gov/index.aspx?NID=2737.

City of San Jose. 2003. Sustainable energy policy action plan.

http://www.sanjoseca.gov/esd/natural-energy-resources/PDFs/ER-EnergyPolicy.pdf.

City of San Jose. 2004. Telecommuting policy.

http:/ / www.mef101.org/Resources/1.7.2\%20Telecommuting\%20(2004).pdf.

Convey, Eric. 2010. Denver ranks $4^{\text {th }}$ in telecommute study. Denver Business Journal.

http://www.bizjournals.com/denver/stories/2010/03/08/daily33.html (accessed

December 10, 2012).

Coroma, Vlad C., Lorenz M. Hilty, and Martin Birtel. 2011. Effects of internet-based multiplesite conferences on greenhouse gas emissions. Telematics and Informatics 29: 362-374.

Corpuz, Grace. 2011. An empirical assessment of teleworking using the Sydney household travel survey data. Australasian Transportation Research Forum.

County of Los Angeles. 2012. County telework program procedures.

http:/ / file.lacounty.gov/bos/supdocs/022212_Memo.pdf.

County of Los Angeles. 2008. Telewoking program.

http:/ / countypolicy.co.la.ca.us/BOSPolicyFrame.htm.

County of Santa Clara. 2012. Teleworking program handbook for CEMA represented

classifications: Including policies and procedures. http:/ / sccema.org/wp-

content/uploads/2010/10/Telework_Program_Policy_CEMA-FINAL.pdf.

County of Santa Clara. 2009. Climate action plan for operations and facilities.

http://www.sccgov.org/sites/osp/Climatepercent20Actionpercent20Plan/Documents /CAPOF_2009_09_29FINAL.pdf.

County of Santa Clara. 1994. Santa Clara county general

plan.http:/ / www.sccgov.org/sites/planning/PlansPrograms/GeneralPlan/Pages/GP. $\underline{\text { aspx. }}$

Cox, W. 2009. Improving quality of life through telecommuting. The Information Technology and Innovation Foundation. http:/ / www.itif.org/files/Telecommuting.pdf (accessed July 29, 2012).

Cuenot, Francois, Lew Fulton, and John Staub. 2012. The prospect for modal shifts in passenger transport worldwide and impacts on energy use and CO2. Energy Policy 41, 98-106. 
Deloitte Development, LLC. 2012. Federal telework and workplace flexibility solutions: Moving from compliance to competiveness.

Denver Regional Council of Governments. 2006. Denver telework toolkit.

Denver Regional Council of Governments. 2012. http://www3.drcog.org/WayToGo/Page/telework (accessed December 10, 2012).

Difiglio, Carmen, and Lewis Fulton. 2000. How to reduce US automobile greenhouse gas emissions. Energy 25: 657-673.

Energy Policy Initiatives Center. 2009. Reducing greenhouse gases from on-road transportation in San Diego county: An analysis of local government policy options. University of San Diego School of Law.

Ettema, Dick. 2010. The impact of telecommuting on residential relocation and residential preferences. The Journal of Transport and Land Use 3, no. 1: 7-24.

Fonner, K. L., \& Roloff, M. E. 2010. Why teleworkers are more satisfied with their jobs than are office-based workers: When less contact is beneficial. Journal of Applied Communication Research 38, no. 4: 336-361.

Geels, Frank W. and Wim A Smit. 2000. Failed technology futures: pitfalls and lessons from a historical survey. Futures 32, nos. 9-10: 867-885.

Grantham, C. E., \& Paul, E. D. 1995. The 'greening' of organizational change: A case study. Innovation: The European Journal Of Social Sciences 8, no. 2: 221-233.

Gurchiek, Kathy. 2009. Survey: Done right, telework ups productivity, job satisfaction. Society for Human Resource Management.

http://www.shrm.org/hrdisciplines/technology/Articles/Pages/TeleworkProductivit y.aspx.

Hamer, Rebecca, Eric Kroes, and Harry Van Ooststroom. 1991. Teleworking in the Netherlands: An evaluation of changes in travel behavior. Transportation 18, no. 4: 365-382.

Harrison, Laird. 2013. San Francisco-Oakland area has the nation's second worst traffic. KQED Public Media for Northern California. http:/ / blogs.kqed.org/newsfix/2013/02/05/sanfrancisco-oakland-area-has-the-nations-second-worst-traffic/.

Hartgen, David T., M. Gregory Fields, Matthew Scott, and Elizabeth San Jose. 2011. Impacts of transportation policies on greenhouse gas emissions in U.S. regions. Reason Foundation: Policy Study 387.

Hill, E., Erickson, J., Holmes, E. K., \& Ferris, M. 2010. Workplace flexibility, work hours, and work-life conflict: Finding an extra day or two. Journal of Family Psychology 24, no. 3: 349358. 
Helling, Amy, and Patricia L. Mokhtarian. 2001. Worker telecommunication and mobility in transition: Consequences for planning. Journal of Planning Literature 15, no 4: 511-525.

Helminen, Ville, and Mika Ristimaki. 2007. Relationships between commuting distance, frequency and telework in Finland. Journal of Transport Geography 15: 331-342.

Hilty, Lorenz M., Peter Arnfalk, Lorenz Erdmann, James Goodman, Martin Lehmann, and Patrick A Wager. 2006. The relevance of information and communication technologies for environmental sustainability- A prospective simulation study. Environmental Modelling \& Software 21: 1618-1629.

Hjorthol, Randi Johanne. 2002. The relation between daily travel and use of the home computer. Transportation Research Part A 36: 437-452.

Hurrell, Bill and Elizabeth Cruz. 2006. Summary of findings, MTC case study: Berkeley, draft 3. MTC Smart Growth Parking Policy Study.

http://www.mtc.ca.gov/planning/smart_growth/parking/parking_study/Nov06/Ber keley_TAC_Draft_3.pdf.

Interview with a 511 representative. 2013. Interview with author. San Jose, CA.

Interview with a Cisco Systems representative. 2013. Interview with author. San Jose, CA.

Interview with a City of Los Angeles representative. 2013. Interview with author. San Jose, CA.

Interview with a City of San Jose representative. 2013. Interview with author. San Jose, CA.

Interview with a City of San Jose representative. 2013. Interview with author. San Jose, CA.

Interview with a City of San Jose representative. 2013. Interview with author. San Jose, CA.

Interview with a City of San Jose representative. 2013. Interview with author. San Jose, CA.

Interview with a County of Santa Clara representative. 2013. Interview with author. San Jose, CA.

Interview with a County of Santa Clara representative. 2013. Interview with author. San Jose, CA.

Interview with a County of Santa Clara representative. 2013. Interview with author. San Jose, CA.

Interview with a County of Santa Clara representative. 2013. Interview with author. San Jose, CA.

Interview with a Juniper Networks representative. 2013. Interview with author. San Jose, CA. 
Interview with a NOAA Santa Rosa Southwest Region representative. 2013. Interview with author. San Jose, CA.

Interview with a Partners Mortgage representative. 2013. Interview with author. San Jose, CA.

Interview with a Shenick Network Systems representative. 2013. Interview with author. San Jose, CA.

Interview with a Somas Mayfair representative. 2013. Interview with author. San Jose, CA.

Irwin, Fran. 2004. Gaining the air quality and climate benefit from Telework. United States Environmental Protection Agency and ATET Foundation.

Koenig Brett E., Dennis K. Henderson, and Patricia L. Mokhtarian. 1996. The travel and emissions impacts of telecommuting for the State of California telecommuting pilot project. Transportation Research Part C 4, no. 1: 13-32.

Lovaas, Deron, Justin Horner, and David Gardiner \& Associates, LLC,. 2011. Fighting Oil Addiction: Ranking states' gasoline price vulnerability and solutions for change. Natural Resources Defense Council.

Lyons, Glenn. 2002. Internet: Investigating new technology's evolving role, nature and effects on transport. Transport Policy 9: 335-346.

Malaczynski, Joanna D., and Timothy P. Duane. 2009. Reducing greenhouse gas emissions from vehicle miles traveled: Integrating the California environmental quality act with the California global warming solutions act. Ecology Law Quarterly 36, no. 1: 71-135. Academic Search Premier, EBSCOhost (accessed August 8, 2012).

Mannering, Jill S., and Patricia L. Mokhtarian. 1995. Modeling the choice of telecommuting frequency in California: An exploratory analysis. Technological Forecasting and Social Change 49: 49-73.

Marvin, Simon. 1997. Environmental flows: Telecommunications and the dematerialization of cities? Futures 29, no. 1: 47-65.

Metropolitan Transportation Commission. 2012. 2012 legislative program.

http://www.mtc.ca.gov/legislation/2012FinalLegisProg.pdf.

Metropolitan Transportation Commission. 2009. Transportation, land use and greenhouse gases: A Bay Area resource guide.

http://www.mtc.ca.gov/planning/climate/Resource_Guide_9-30-09.pdf.

Metropolitan Transportation Commission. 2010. Climate and transportation: Change is coming, by Steve Heminger. PowerPoint Presentation. 
Metropolitan Transportation Commission and Association of Metropolitan Planning Organizations (MTC and AMPO). 2009. BASSTEGG-Sketch planning charrette/GIS models for predicting household vehicle miles traveled (VMT) and greenhouse gas $\left(\mathrm{CO}_{2}\right)$ emissions. PowerPoint Presentation. Chicago, Illinois.

Microsoft (1). 2011. Microsoft 'work without walls' report: U.S. telework trends 2011, by Ipsos Public Affairs. http://www.microsoft.com/en-us/news/download/features/2011/0518remote.pptx (accessed December 10, 2012).

Microsoft (2). 2011. Microsoft remote working now a 'business imperative.' http:/ / www.microsoft.com/en-us/news/features/2011/may11/0518WorkWithoutWalls.aspx (accessed December 10, 2012).

Mokhtarian, Patricia L., and Ravikumar Meenakshisundaram. 1999. Beyond tele-subsitution: Disaggregate longitudinal structural equations modeling of communication impacts. Transportation Research Part C 7: 33-52.

Mokhtarian, Patricia L., Susan L. Handy, and Ilan Salomon. 1995. Methodological issues in the estimation of the travel, energy, and air quality impacts of telecommuting. Transportation Research Part A 29A, no. 4: 283-302.

Moore, Adrian T., Samuel R. Staley, and Robert W. Poole Jr. 2010. The role of VMT reduction in meeting climate change policy goals. Transportation Research Part A 44: 565-574.

The National Institutes of Health. Estimate savings to your pocketbook and the environment by teleworking. http:/ / traffic.nih.gov/pages/telework_cost.aspx (accessed April 7, 2013).

Nelson, Peter. 2004. Emissions trading with telecommuting credits: Regulatory background and institutional barriers. Resources for the Future Discussion Paper.

Nelson, Peter, Elena Safirova, and Margaret Walls. 2007. Telecommuting and environmental policy: Lessons from the ecommute program. Transportation Research Part D 12: 195-207.

Newsom, Gavin. 2005. Executive directive to implement telecommuting pilot program. Memorandum.

Nilles, Jack M. 1993. City of Los Angeles telecommuting project. Los Angeles: JALA International, Inc.

Plaut, Pnina O. 2005. Non-motorized commuting in the US. Transportation Research Part D 10: 347-356.

Ramaswami, Anu, Meghan Bernard, Abel Chavez, Tim Hillman, Michael Whitaker, Gregg Thomas, and Matthew Marshall. 2012. Quantifying carbon mitigation wedges in U.S. cities: Near-term strategy analysis and critical review. American Chemical Society 46: 36293642. 
Rapino, Melanie A. and Alison K. Fields. 2013. Mega commuters in the U.S.: Time and distance in defining the long commute using the American community survey. United States Census Bureau.

Rhee, Hyok-Joo. 2009. Telecommuting and urban sprawl. Transportation Research Part D 14: 453460.

Ride Arrangers Denver Regional Council of Governments (1). Telework case study: Alpine Access.

http:/ / www3.drcog.org/waytogo/ content/documents/Casepercent20Studiespercent2 0Alpinepercent20Access.pdf (accessed December 10, 2012).

Ride Arrangers Denver Regional Council of Governments (2). Telework case study: Rocky Mountain Center for Health Promotion and Education.

http:/ / www3.drcog.org/waytogo/content/documents/Casepercent20Studiespercent2 ORockypercent20Mountainpercent20Center.pdf (accessed December 10, 2012).

Ride Arrangers Denver Regional Council of Governments (3). Telework case study: SKLD Information Services.

http://www3.drcog.org/waytogo/content/documents/Casepercent20Studiespercent2 0SKLD.pdf (accessed December 10, 2012).

Salon, Doborah, Marlon G. Boarnet, Susan Handy, Steven Spears, and Gil Tal. 2012. How do local actions affect VMT? A critical review of empirical evidence. Transportation Research Part D 17: 495-508.

San Francisco Municipal Transportation Agency (SFMTA). 2011. 2011 San Francisco climate action strategy for San Francisco's transportation system.

San Jose State University. 2009. Telecommuting policy. http:/ / www.sjsu.edu/hr/docs/risk/policies/telecommute_pkg.pdf.

Rosenberg, Mike. 2013. Bay Area tops new 'mega-commuter' Census list defining the worst trips to work. San Jose Mercury News. http:/ / www.mercurynews.com/traffic/ci_22717273/bay-area-tops-new-megacommuter-census-list (accessed March 8, 2013).

Santa Clara County (SCC). 2009. Climate action plan for operations and facilities.

http://www.sccgov.org/SCC/docspercent2FCountypercent20Executive, percent20Offic epercent20ofpercent20thepercent20(DEP) percent2Fattachmentspercent2FCAPOF_2009 09 29FINAL.pdf.

Shaheen, Susan A., Jade Benjamin-Chung, Denise Allen, and Linda Howe-Steiger. 2009. Achieving California's land use and transportation greenhouse gas emission targets 
under AB32: An exploration of potential policy processes and mechanisms. California Air Resources Board and the California Department of Transportation.

State of California. 2008. EXECUTIVE ORDER S-04-08. http://gov.ca.gov/ news.php?id=9629.

Stopher, Peter R. 2004. Reducing road congestion: A reality check. Transport Policy 11: 117-131.

Su, Quig, and Liren Zhou. 2012. Parking management, financial subsidies to alternatives to drive alone and commute mode choices in Seattle. Regional Science and Urban Economics 42: 88-97.

Tayyaran, Mohammad R., and Ata M. Khan. 2007. Telecommuting and residential location decisions: Combined stated and revealed preferences model. Canadian Journal of Civil Engineering 34: 1324-1333.

Telework Research Network. 2011. The bottom line on telework: California government workforce. 2011 Work Anywhere Symposium. Sacramento State University.

The Huffington Post. 2013. Yahoo CEO Marissa Mayer demands telecommuters report to the office. http://www.huffingtonpost.com/2013/02/23/yahoo-workingremote_n_2750698.html (accessed February 27, 2013).

Tonn, Bruce E., and Angela Hemrick. 2004. Impacts of the use of e-mail and the internet on personal trip-making behavior. Social Science Computer Review 22: 270-280.

Transportation Demand Management Institute. 1997. TDM case studies and commuter testimonials. http:/ / www.epa.gov/oms/stateresources/rellinks/docs/tdmcases.pdf.

United States Department of Transportation Research and Innovative Technology Administration. Transportation implications of telecommuting. RITA National Transportation Library. http:/ / ntl.bts.gov/DOCS/telecommute.html (accessed August 31, 2012).

United States Office of Personnel Management. 2010. A guide to telework in the federal government. http:/ / www.opm.gov/pandemic/agency2a-guide.pdf.

U.S. Census Bureau. 2010. Table DP-1: Profile of general population and housing characteristics. http://factfinder2.census.gov/.

U.S. Census Bureau. 2010. QuickFacts: http:/ / quickfacts.census.gov/gfd/states/06/0668000.html.

U.S. Census Bureau . 2010. Table DP-1: Profile of general population and housing characteristics: 2010. http://factfinder2.census.gov/.

U.S. Census Bureau. ACS 2009-2011 3 year estimate, table DP03: Selected economic characteristics. http:/ / factfinder2.census.gov/. 
U.S. Census Bureau. Census SF3: B08101 means of transportation to work 16 years and over (2008-2010).

http:/ / factfinder2.census.gov/faces/tableservices/jsf/pages/productview.xhtml?pid= ACS_10_3YR_B08101\&prodType=table.

U.S. Census Bureau. Table GCT0801: Workers 16 years and over who did not work at home (2008-2010).

http:/ / factfinder2.census.gov/faces/tableservices/jsf/pages/productview.xhtml?pid= ACS_10_3YR_GCT0801.ST10\&prodType=table

U.S. Congress. Senate. 2010. Telework enhancement act of 2010. 111 th Cong., 2nd sess. S. Doc. 111177.

United States Office of Personnel Management. A guide to telework in the federal government. http://www.opm.gov/pandemic/agency2a-guide.pdf.

Valley Transportation Authority. 2011. Congestion management program. 


\section{Appendix A: Interviews}

Table 4: Interview Transcripts

\begin{tabular}{|c|c|c|}
\hline & Organization & Feedback \\
\hline 1 & $\begin{array}{l}\text { A City of San Jose Air } \\
\text { Compliance Intern } \\
\text { (Interview with a City of } \\
\quad \text { San Jose } \\
\quad \text { representative. } 2013 \text {. } \\
\quad \text { Interview with } \\
\text { author. San Jose, CA.) }\end{array}$ & $\begin{array}{l}\text { The City of San Jose has an official telecommuting policy. She searched the City's intranet for } \\
\text { VMT and vehicle miles traveled and did not find any data concerning employee commuting } \\
\text { habits or emissions reductions. She is not sure how affective the telecommuting policy is or what } \\
\text { the answers are to any of the data inquires. }\end{array}$ \\
\hline 2 & $\begin{array}{l}\text { A City of San Jose HR } \\
\text { representative } \\
\text { (Interview with a City of } \\
\quad \text { San Jose } \\
\quad \text { representative. } 2013 . \\
\quad \text { Interview with } \\
\quad \text { author. San Jose, CA.) }\end{array}$ & $\begin{array}{l}\text { The department of transportation is concerned with the streets themselves, not how people get to } \\
\text { and from work. The department of planning is not concerned with the City's employees per se, } \\
\text { so they don't collect commute data. The VTA may be the ones who collect the commute data. The } \\
\text { City may not collect this type of commute data (she checked with her boss). This is an indication } \\
\text { of a data gap. She suggested submitting a public records request for the information and if the } \\
\text { City has it, I can get a copy. I did this on } 2 / 15 / 13 \text {. At the City they have an employee relations } \\
\text { department which would handle telecommuting request instead of HR. }\end{array}$ \\
\hline 3 & $\begin{array}{l}\text { Juniper Networks } \\
\text { representative } \\
\text { (Interview with a Juniper } \\
\quad \text { Networks } \\
\text { representative. } 2013 \text {. } \\
\text { Interview with } \\
\text { author. San Jose, CA.) }\end{array}$ & $\begin{array}{l}\text { Juniper has an official telecommuting policy and it is up to the managers to decide if the } \\
\text { employee can participate. From personal experience, the representative saved a one-way } \\
\text { commute distance of } 12 \text { miles a day when telecommuting. The representative would use a } \\
\text { desktop sharing program like WebEx to allow simulated in-person interactions if needed while } \\
\text { telecommuting. Juniper would have annual energy reduction contests where they may have } \\
\text { recorded things like VMT and GHG reductions. Juniper required that the home office was up to } \\
\text { OSHA standards with ergonomic desk and seating. The representative also used video phones } \\
\text { and video chats. Juniper has 9,584 employees and the average telecommuter works from home } \\
\text { about one day per week. Juniper does have an official telecommuting policy (see saved article). }\end{array}$ \\
\hline 4 & $\begin{array}{l}\text { Shenick Network } \\
\text { Systems representative } \\
\text { (Interview with a Shenick } \\
\text { Network Systems } \\
\text { representative. } 2013 \text {. } \\
\text { Interview with }\end{array}$ & $\begin{array}{l}\text { Shenick does not have a formal telecommuting policy and it is done on a case-by-case basis. } \\
\text { Shenick has around } 50 \text { employees based in CA, Ireland, and the East Coast. Telecommuting in } \\
\text { some form is therefore built into the daily operations of the company's work. The average } \\
\text { telecommuter works from home about one day per week. } \\
\text { The criteria is: } \\
\text { - On a case-by-case basis }\end{array}$ \\
\hline
\end{tabular}


author. San Jose, CA.) - Firstly, do they trust the employee to do the work at home and complete tasks?

- Depends the job - coders don't really need to interact with machines/equipment

- QA position/test position - usually requires more equipment interaction/setup/cable changing, etc. etc.

- QA may be asked on a whim by someone in an office, especially from long distance to reboot machines, set something up, etc.

$5 \quad$ Santa Rosa Southwest Region of the NOAA The NOAA has a formal telecommuting policy (see link) and employees are allowed to work up representative

(Interview with a NOAA

Santa Rosa Southwest

Region representative.

2013. Interview with

author. San Jose, CA.)

6 County of Santa Clara

representative

(Interview with a County of

Santa Clara

representative. 2013.

Interview with to two days a week from home with manager approval. The representative didn't have access to data on the effectiveness of the telecommuting policy. All employees are eligible to telecommute with manager approval as long as they have been employed with them for one year serving five days in the office a week; then they can telecommute up to two days a week. Most of the employees live in the Santa Rosa area, but a few employees live in San Francisco. All the telecommuters work from home part-time.

author. San Jose, CA.)

This representative worked on the 2009 Climate Action Plan which lists telecommuting as a GHG reduction strategy. They did it to support a pilot in the ISD (Information Services Division). Also, the union (CEMA) that some employees are a part of supported telecommuting. They did the pilot to get telecommuting to be accepted politically. They choose telecommuting as a strategy because it made a lot of sense and people requested it in a commute survey they conducted (it was the number one choice). It was identified as a strong possibility, but the culture was not supportive of it. This is why they did the pilot in ISD. Managers are worried that if the employee telecommutes, they will not be working. Now the union is on board and has written it into their contract. Linda Furnas from 511.org was instrumental in supporting the County's telecommuting pilot by providing free consultants.

$7 \quad$ Cisco Systems

- Is in the office two days a week on average and works from home three days a week.

(Interview with a Cisco Systems

- Cisco collaborative workspaces: people have home-base building, but can work wherever they want (not assigned spots). They get a drawer, a phone, and a monitor only.

representative. 2013.

Interview with author. San Jose, CA.)

- Cisco hires a lot of outside companies to push policies like remote work (see CB Richard Ellis who is a builder who helps with facilities management)

- Cisco can track building usage via badges and helps them decide which buildings to shut down because they are not being fully utilized. This cuts down on GHGs.

- Cisco is selling off some of their buildings due to more remote work on a full- and part-time basis. Typically no more than 50percent of employees are at the office at a time.

- Erica's Team: one lives in China, North Carolina and Texas; they video conference 


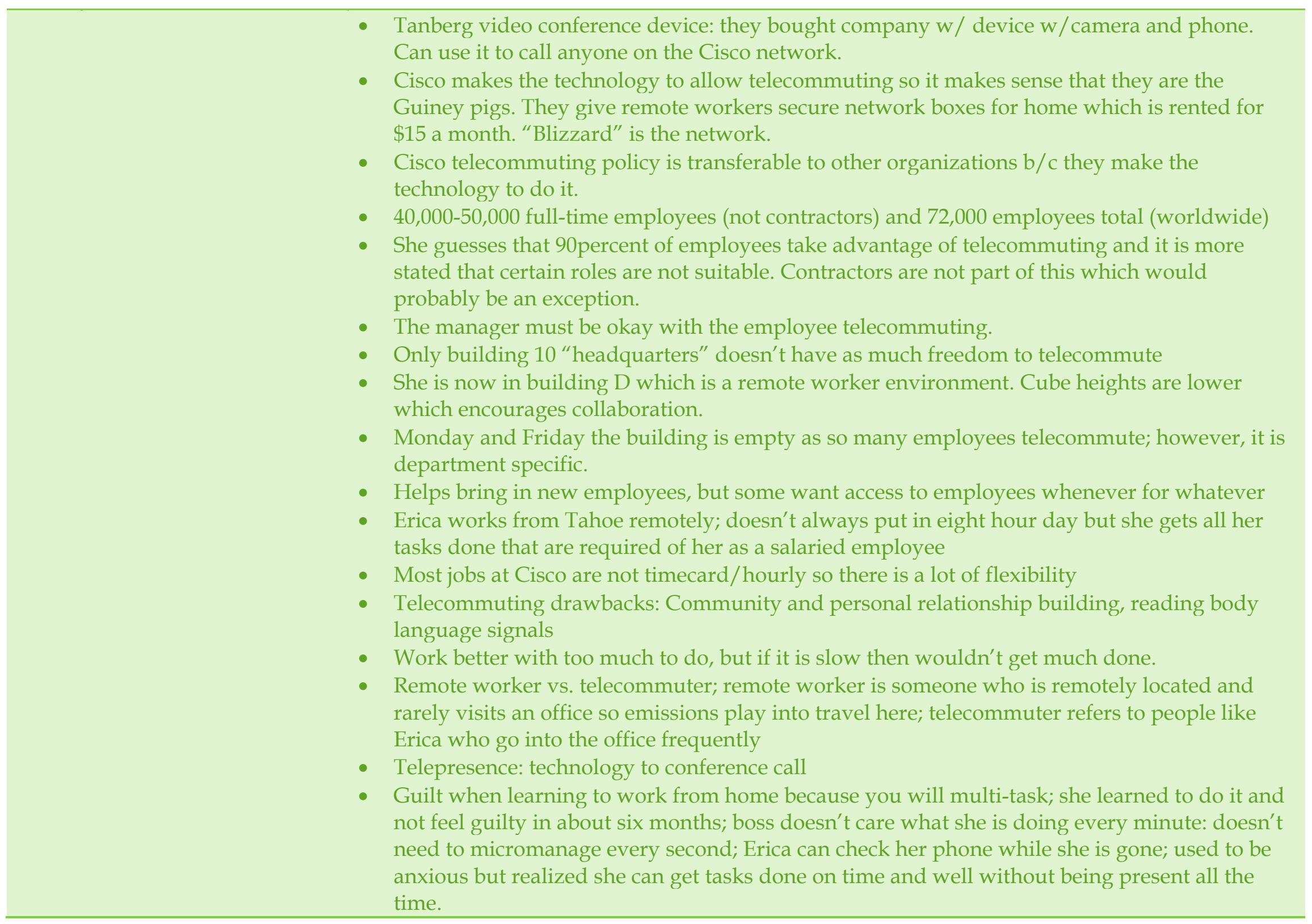




\begin{tabular}{|c|c|c|}
\hline & & $\begin{array}{l}\text { - Don't have to pay huge overhead to try out telecommuting because they offer the } \\
\text { technology/produce it themselves } \\
\text { - Ping and email are the biggest forms of communication } \\
\text { - Naysayers and abusers of telecommuting everywhere: issues of unrest from those who do not } \\
\text { telecommute saying telecommuters are not working } \\
\text { - Manager perceptions: there is something to be said for those who interact in person with } \\
\text { colleagues like reading body signals } \\
\text { - Some people don't like to have work in their home; life gets convoluted } \\
\text { - Negotiations may be easier in hallways run-ins rather than email or phone; can "catch" } \\
\text { - Needs to be balance of the two; freedom to work from home; can help in daughter's } \\
\text { classroom in morning then work in the afternoon from home. } \\
\text { - Helps morale } \\
\text { unintentionally pushed out of the inner circle. }\end{array}$ \\
\hline 8 & $\begin{array}{l}\text { City of Los Angeles } \\
\text { representative } \\
\text { (Interview with a City of } \\
\text { Los Angeles } \\
\text { representative. } 2013 . \\
\text { Interview with } \\
\text { author. San Jose, } \\
\text { CA.) }\end{array}$ & Only the Police Department telecommutes. \\
\hline 9 & $\begin{array}{l}\text { 511.org representative } \\
\text { (Interview with a } 511 \\
\text { representative. } 2013 . \\
\text { Interview with } \\
\text { author. San Jose, } \\
\text { CA.) }\end{array}$ & $\begin{array}{l}\text { - Took almost } 3 \text { years to get the SCC pilot going and official training implemented } \\
\text { - Pilot went really well, changes from upper management needed and a cultural shift from } \\
\text { middle management the hardest } \\
\text { - Middle managers can have misconceptions about telecommuting like they will lose touch } \\
\text { with employees and employees will not be working during paid hours or be as productive } \\
\text { - Productivity is something that employers have to measure, but } 511 \text { can measure GHGs } \\
\text { through trip diaries. Trip diaries also help justify a telecommuting program/policy. A time- } \\
\text { series analysis shows effectiveness for GHGS. } \\
\text { - } 511 \text { promotes all options that are out there and talk to each employer with specific options as } \\
\text { is appropriate for employer based on site location, employee tasks, transit access, and }\end{array}$ \\
\hline
\end{tabular}




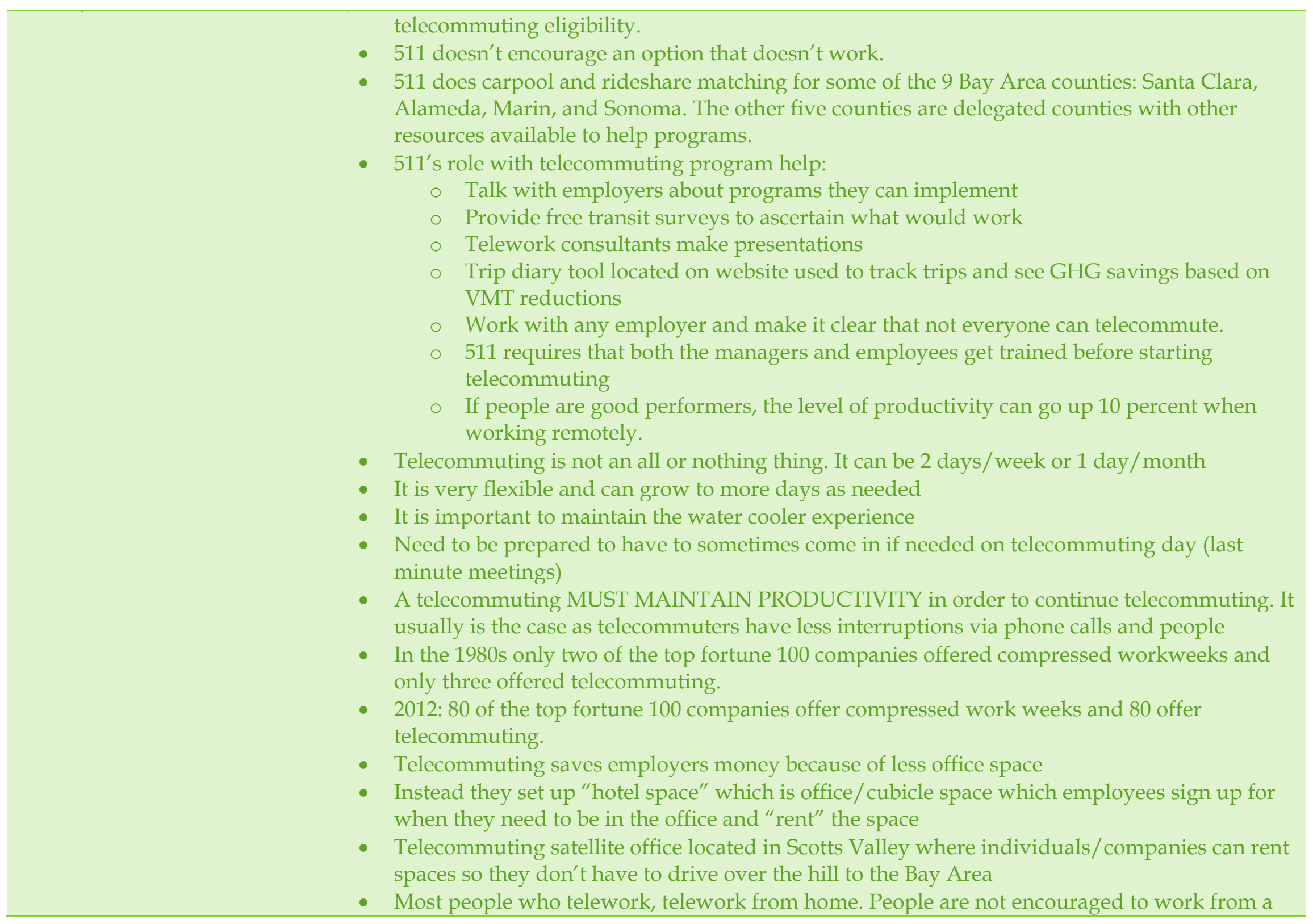


Starbucks or other public locations because they are full of distractions and don't provide the same information security

- Have to have good policy stating what is and is not allowed:

- If you are sick then don't work unless able so you don't spread germs. However, if you are too sick to go to work, but not too sick to not work, then telecommuting provides an opportunity to not take sick leave and maintain productivity

- Not a substitute for child or elderly care

- Must have a quite work space

- Can be used as an option if taking care of a sick child, but is not the goal of telecommuting

- Important to establish rituals to make your telecommuting workday serious:

- An employee would get up and put on his badge and work from home. When his children came home from school they would see that their father was wearing his badge and that meant he was working and should not be disturbed.

- Telecommuters must utilize rituals and make sure to take breaks and lunch

- Some companies may require you to have "punching time card" methods to keep people on track. Can use something like an "in and out board"

- Need to figure out how an employee will get their phone calls (forwarded, cell phone, on the computer?)

- How quickly do you need to return and phone call or email?

- Upper management will want telecommuting, but middle management may not like it because they can't see their employees (hard to get buy-in)

- 511 case studies show VMT and GHG reductions

- Not yet done case study for SCC or others to show major reduction (very new program)

- Slow process because employee and manager must both attend a training before participation

- Correct equipment must be at the home (checklist)

- Consultant 511 works with has promoted telecommuting for over 20 years with the federal government and others

- Work with lots of employers in the Bay Area to fine tune their policies

- Large number of employers have informal policies with no statistics on case by case

- 511 is encouraging the adoption of formal policies 


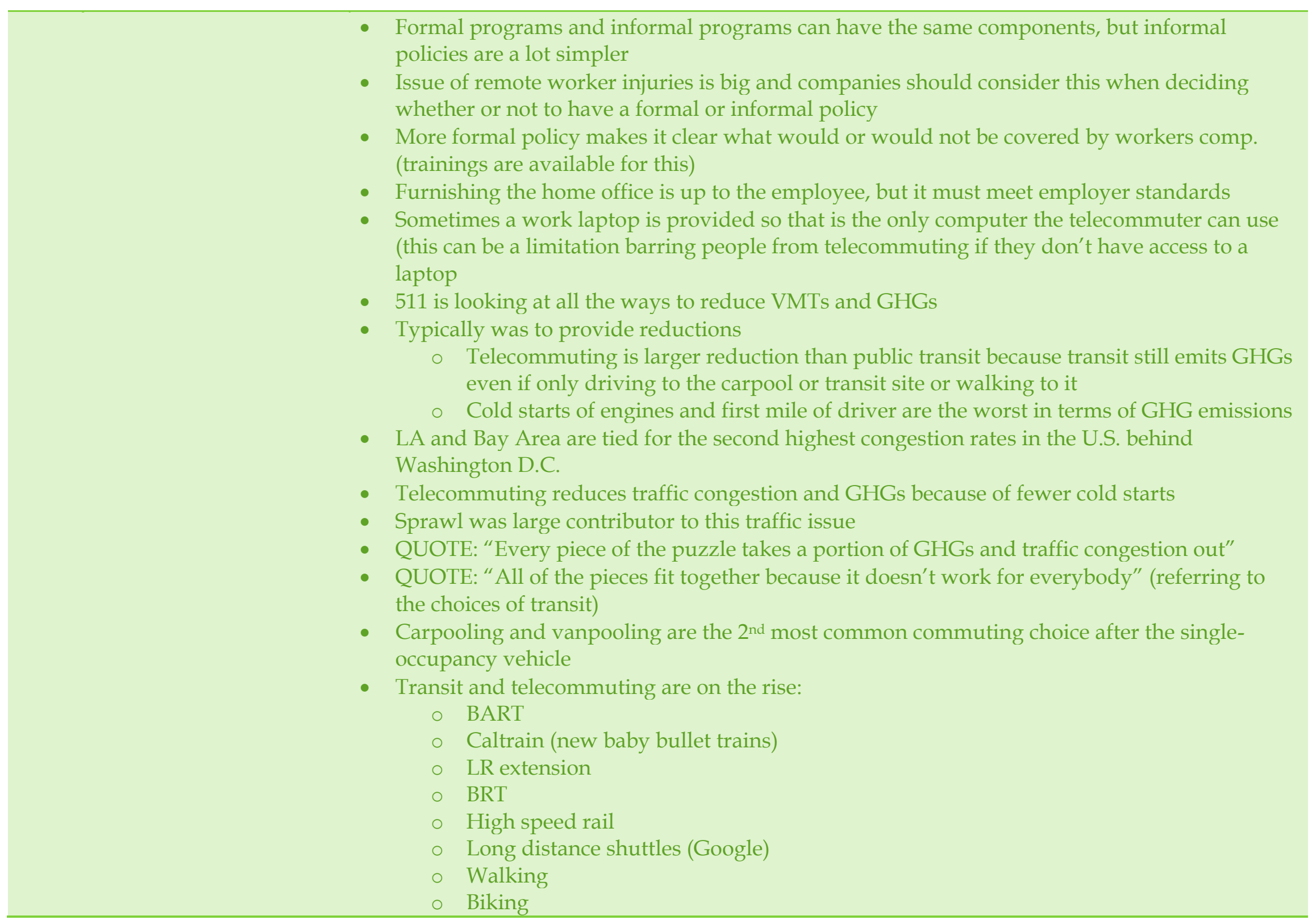




\begin{tabular}{|c|c|c|}
\hline & & $\begin{array}{l}\text { - Telecommuting } \\
\text { The more people that telecommuting, the better off we will be by removing cars from the } \\
\text { road. Goods will move faster and people will move faster. It will reduce emissions }\end{array}$ \\
\hline 10 & $\begin{array}{l}\text { County of Santa Clara, } \\
\text { Information Technology } \\
\text { Support Services } \\
\text { representative } \\
\text { (Interview with a County of } \\
\quad \text { Santa Clara } \\
\quad \text { representative. } \\
\text { 2013. Interview } \\
\text { with author. San } \\
\text { Jose, CA.) }\end{array}$ & 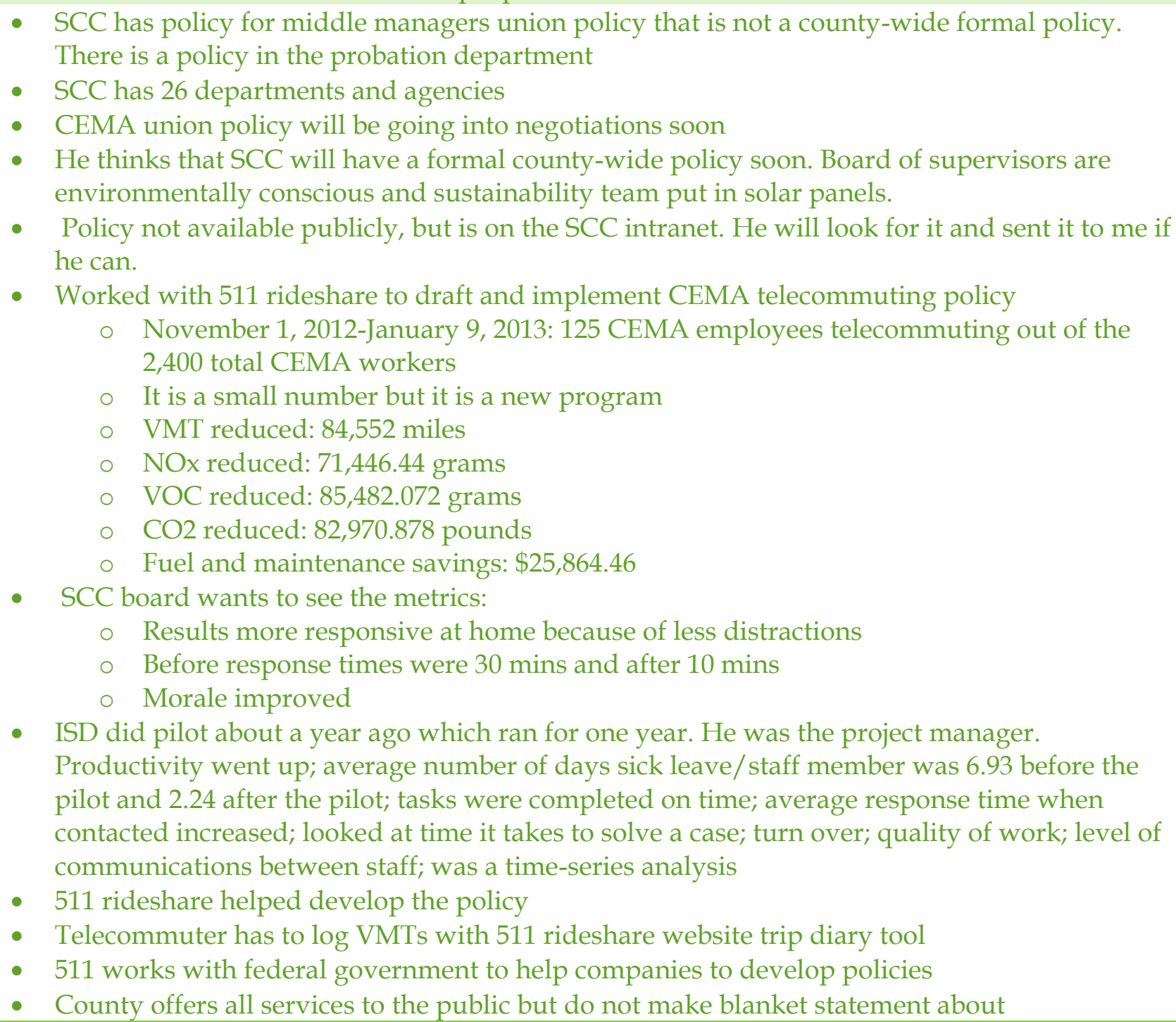 \\
\hline
\end{tabular}


telecommuting edibility. Sometimes IT can do it as well as other workers, but not always.

- He does GIS, data centers and enterprise databases. Data center must be staffed 24/7x365 so telecommuting not working there.

- Telecommuters sometimes work more hours than scheduled 8 hours (adding commuting hours to work day)

- Manager style is important and a cultural shift has to occur

- When CEMA policy was created, used 511, probation and ISD as reference

- 511: dispelled the myths about telecommuting and provided online trip diary to capture metrics

- Manager and staff have to attend trainings on how to telecommuting which is a collaboration between 511 and SCC

- 17,000 employees including extra help with 12,000 full-time

- Only CEMA is eligible to telecommute

- CEMA defines eligibility in contract. Job would allow work via remote work, manager acceptance who have the final say and new employees have a probation period, can't have discipline problems.

- 2 days/week is average

- No full-time telecommuters

- Some employees may take advantage of it. It is not a replacement for child care, not a time to run errands, and employee must be reachable.

- Program is working out well

- Relatively new program so still changing (Oct 2012)

- Have to fill out form to telecommute and do checklist

- Can appeal manager's denial if needed if reason is not valid (talk to labor relations)

- QUOTE: It's great. Glad county is finally doing it as it benefits all of them. Environment very important reduces pollution

11 Santa Clara Valley Health \& Hospital System representative (Interview with a County of Santa Clara representative. 2013. Interview
- CEMA used 511 to help draft policy and to track VMT and GHG savings

- Not like federal program it is union specific: contract covers all people even if they are not in the union they are in CEMA represented class so they are covered by telecommuting policy

- Can see examples in screen shots in CMEA policy of GHG and VMT reductions (back of policy talking about trip diaries)

- She is surprised that SJ doesn't have GHG/VMT calculations

- Cities and Counties are banding together to make it safer here in Bay Area from VMTs and 


\begin{tabular}{|c|c|c|}
\hline & $\begin{array}{l}\text { with author. San } \\
\text { Jose, CA.) }\end{array}$ & 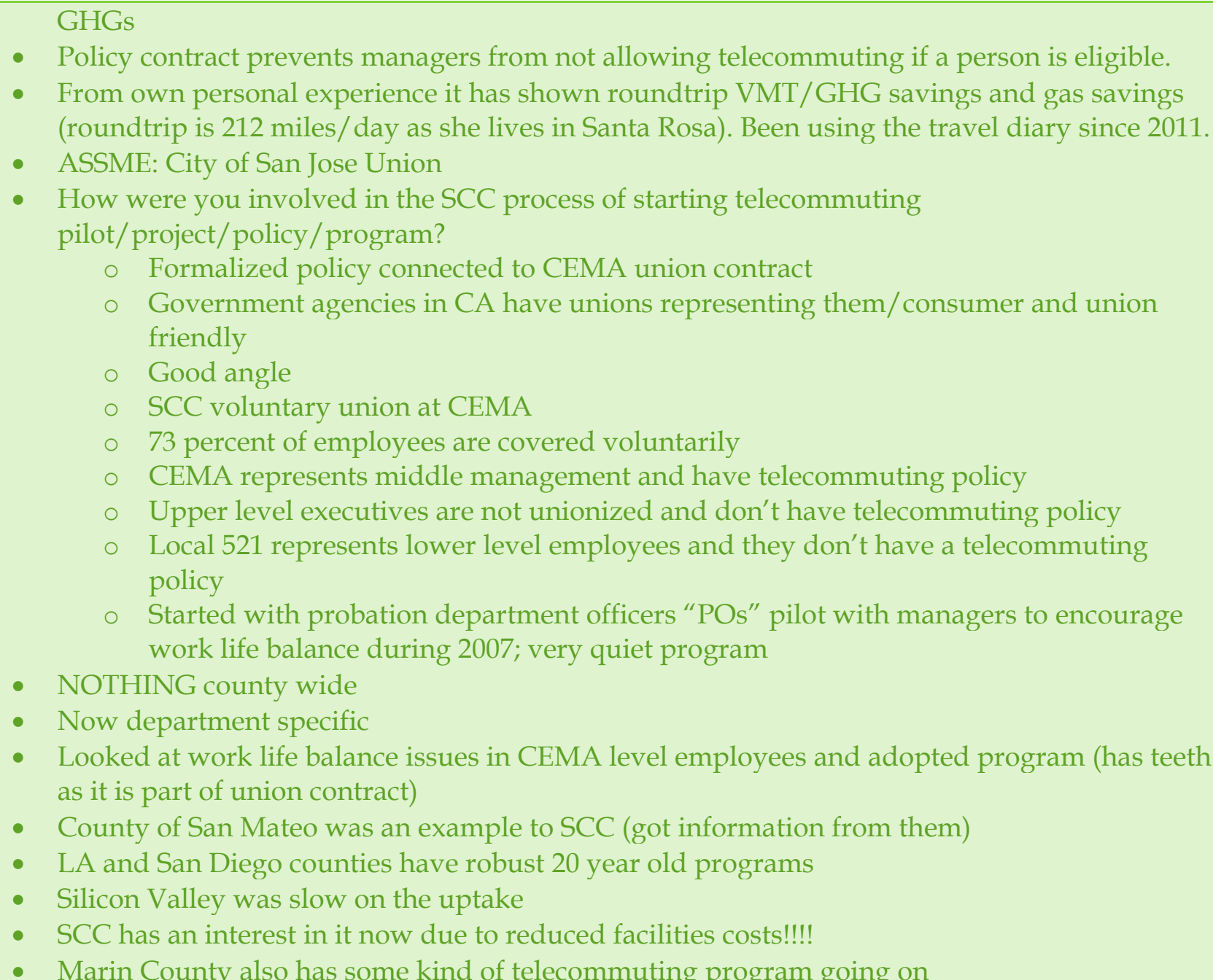 \\
\hline 12 & $\begin{array}{l}\text { Representative from the } \\
\text { City of San Jose } \\
\text { (Interview with a City of } \\
\quad \text { San Jose } \\
\quad \text { representative. }\end{array}$ & $\begin{array}{l}\text { - Telecommuting was mentioned by the Envision San Jose } 2040 \text { General Plan in the "work from } \\
\text { home" category in the baseline mode share for } 2008 \text { in Policy TR-1.1 } \\
\text { The General Plan does include goals for which telecommuting is implied: } \\
\text { o TR-1.3: Increase substantially the proportion of commute travel using modes other } \\
\text { than the single-occupant vehicle. The } 2040 \text { commute mode split targets for San Jose }\end{array}$ \\
\hline
\end{tabular}


2013. Interview with author. San Jose, CA.)

Camille LlanesFontanilla of Somas Mayfair (Interview with a Somas Mayfair representative. 2013. Interview with author. San Jose, CA.) residents and workers are presented in the following table. (modes other than singleoccupant vehicle" includes "work at home.")

- There is also one reference to telecommuting in the discussion of TDM measures:

- Transportation Demand Management and Parking: Transportation Demand Management (TDM) refers to a set of strategies to reduce vehicle trips by promoting alternatives such as staggered or flexible work hours, public transit, carpooling, bicycling, walking, telecommuting...

- Somas Mayfair does not currently have a telecommuting policy, but they are interested in starting one. People are requesting it at initial hire and it will be written into their contracts (change of relationship form)

- Camille's is informal verbal agreement

- Food just like statement has environmental policy

- No emissions goals but talks about role in reducing waste

- Company is aware of telecommuting benefits: more about flexibility and productivity. Stems from management and lots of workers have to do writing and need a quiet space so telecommuting allows for quiet space at home then grew into work life balance with family growing

- Limited infrastructure and time; operations department role changing frequently but now more stable financially and staff wise

- It would be good to have because it would protect the company because people take current flexibility for granted. People start being late or work from home without approval.

- Written policy would protect productivity and not take for granted freedom.

- Costs savings to reduce VMTs by allowing telecommuting before meetings because they pay for driving

- They have 13 employees

- 12 are eligible to telecommute if necessary but not ideal because of on the ground nature of work.

- Helps with traffic issues (one employee drives from Gilroy to San Jose and gets stuck in bad traffic. They rather she telecommutes then come in if traffic is bad making her more productive.)

- Eligibility defined: does job description allow for 80 percent of job to be done via telecommuting (i.e. external meetings, email, writing)?

- Most employees live very close to work with exception of Gilroy employee (within 5-10 miles 


\begin{tabular}{|c|c|c|}
\hline & & $\begin{array}{l}\text { and executive director walks to work) } \\
\text { - } \text { Part-time telecommuting only and } 1 \text { day a week only } \\
\text { - Neep discretion open even with formal telecommuting policy } \\
\text { - Camille's perspective: when her grandmother was in hospice, she was able to keep up with } \\
\text { her work and be with her grandmother because of telecommuting. This way she didn't have } \\
\text { to call in sick to be with her grandmother. } \\
\text { - Infrastructure needs to be increased to make it easier } \\
\text { - IT infrastructure not the best have sever where we can access email but getting other } \\
\text { information is hard to get consistent connection } \\
\text { - Have to get better connection } \\
\text { - Computer skills and literacy is a limitation for switching over to cloud computing. }\end{array}$ \\
\hline 14 & $\begin{array}{l}\text { A City of San Jose } \\
\text { representative } \\
\text { (Interview with a City of } \\
\text { San Jose } \\
\text { representative. } \\
\text { 2013. Interview } \\
\text { with author. San } \\
\text { Jose, CA.) }\end{array}$ & $\begin{array}{l}\text { - San Jose has had the policy since } 2004 \\
\text { - Perspective: want people to reduce GHGs and VMTs but they are a service organization, } \\
\text { direct service needed so can't always telecommute } \\
\text { - } 5,400 \text { full-time employees } \\
\text { - } 7,000 \text { total employees } \\
\text { - Employees that can't telecommute: police, fire fighters, plant operators, pave streets, } 911 \\
\text { dispatchers, etc. (because they are in the field interacting with the public or doing jobs that } \\
\text { are physical) } \\
\text { - Where it is possible, we leave it up to the City department to determine where and when it is } \\
\text { - Full-time telecommuting is not good for team-oriented projects so part-time telecommuting is } \\
\text { - } \text { - It CAN work but practicalities for delivering service. } \\
\text { - QUOTE: "we are here to work with the community" } \\
\text { - Employees that CAN telecommute: architects, engineers, etc. } \\
\text { - San Jose has no studies on the effectiveness of telecommuting on reducing VMTs and GHGs } \\
\text { - He considers the policy transferable to other Cities and organizations. They share with people } \\
\text { - } \text { all the time so they don't have to reinvent the wheel } \\
\text { - Hard to speculate if telecommuting has helped City reduce GHGs to meet federal, state or }\end{array}$ \\
\hline
\end{tabular}


Kimberly Yearry, Branch Coordinator at Partners Mortgage

(Interview with a Partners Mortgage representative. 2013. Interview with author. San Jose, CA.) other regulations, but should be working. No formal study. It is flexible telecommuting but let's say a person needs to stay at home for some reason, then it can work to promote work life balance and reduce VMT. Only on a periodic basis.

- Can't provide any data on the program because they don't track the data centrally. It would be a department specific data collection. The current policy is informal as far as collecting data and doesn't track numbers.

- VMTs for city vary and employees live both close and far away

- Informal telecommuting policy (not written in anything)

- Arrangement is usually documented in email between employee and supervisor

- They don't have any environmental goals

- They encourage carpooling when able, but only for convenience and gas savings

- Personal experience:

○ Kim loved telecommuting

- Had to do it for 6 weeks while on bed rest for an illness

- Allowed her to collect disability (only pays 60percent of salary) and work part-time via telecommuting to make the bills

- Her productivity increased due to less distractions from phone calls and people - Took conference calls at home

- Checked in over the phone with her boss

- Didn't need to talk over the phone or see people in-person all the time before illness and after illness it put it in perspective that telecommuting doesn't limit the needed interaction

- Didn't see her manager much when working in the office and after sick leave, during telecommuting she talked to her boss more on the phone

- Work-life balance reasons (why most of the employees do it)

- 60 employees

- 90 percent eligible to telecommute (only receptionist not able to telecommute)

- Another limitation is the confidentially of work so people have to make sure files are secured in a locked brief case if traveling home to telecommute and lock away at home when not using them.

- Average employee commute: from 1 mile to Burlingame (this person telecommutes 2 days/week)

- Part-time only 


\begin{tabular}{|c|c|c|}
\hline & & $\begin{array}{l}\text { - Varies from } 2 \text { days/month or } 2 \text { days/week or a few hours per day } \\
\text { - Flexibility big part of it } \\
\text { - HR lady works from home } 2 \text { hours/day because she has to pick up kids } \\
\text { - Everyone has remote access when hired to make telecommuting easier (set up on IT check } \\
\text { list) }\end{array}$ \\
\hline 16 & $\begin{array}{l}\text { A County of Santa Clara } \\
\text { representative } \\
\text { (Interview with a County of } \\
\text { Santa Clara } \\
\text { representative. } \\
\text { 2013. Interview } \\
\text { with author. San } \\
\text { Jose, CA.) }\end{array}$ & $\begin{array}{l}\text { - Must consider type of work performed by employee when considering telecommuting } \\
\text { eligibility. } \\
\text { - QUOTE: "It's not as easy for a government entity to allow many workers to telecommute } \\
\text { because a lot of the work performed is direct customer interaction." } \\
\text { - She is not familiar with the SCC CEMA telecommuting policy. }\end{array}$ \\
\hline
\end{tabular}

Table 5: Common Themes Derived from the Interviews

\begin{tabular}{|c|c|c|}
\hline $\begin{array}{l}\text { Common themes derived } \\
\text { from interviews }\end{array}$ & Mentioned by & In literature review? \\
\hline Work-life balance & $\begin{array}{l}\text { SCC (telecommuters sometimes work more hours); } \\
\text { Somas Mayfair (family needs); Partners Mortgage }\end{array}$ & None \\
\hline Cost savings & $\begin{array}{l}\text { Cisco (Don't have to pay huge overhead to try out } \\
\text { telecommuting because they offer the } \\
\text { technology/produce it themselves); Somas Mayfair; }\end{array}$ & $\begin{array}{l}\text { Theme 2: Brewer 1998; Moore, Staley and } \\
\text { Poole Jr. 2010; Lyons 2002; Hartgen, Fields, } \\
\text { Scott and San Jose 2011; }\end{array}$ \\
\hline Formal policy in place & $\begin{array}{l}\text { City of San Jose; Juniper Networks; NOAA; SCC (CEMA } \\
\text { only in union contract; prevents managers from not } \\
\text { allowing telecommuting if person is eligible); Cisco } \\
\text { Systems (Cisco collaborative workspaces; Tanberg video } \\
\text { conference device; Blizzard secure network box; } \\
\text { telepresence); } 511 \text { (companies encouraged to have formal } \\
\text { policy as it protects them); }\end{array}$ & $\begin{array}{l}\text { Theme 3, sub-theme 1: Nelson, Safirova } \\
\text { and Walls 2007; Theme 2: Lyons 2002; } \\
\text { Gardiner, Lovaas and Horner 2011; }\end{array}$ \\
\hline $\begin{array}{l}\text { Informal policy in place or } \\
\text { no policy }\end{array}$ & $\begin{array}{l}\text { Shenick; Somas Mayfair (written into contract at hire } \\
\text { date or just verbal agreement); Partners Mortgage }\end{array}$ & None \\
\hline Data gap & City of San Jose; & None \\
\hline
\end{tabular}




\begin{tabular}{|c|c|c|}
\hline Manager discretion & $\begin{array}{l}\text { Juniper Networks; Shenick; NOAA; Cisco; Somas } \\
\text { Mayfair; City of San Jose (department specific); Partners } \\
\text { Mortgage }\end{array}$ & None \\
\hline OSHA standards & Juniper Networks; & None \\
\hline $\begin{array}{l}\text { Average \# days worked } \\
\text { from home/week }\end{array}$ & $\begin{array}{l}\text { Juniper Networks: } 1 \text {; Shenick: } 1 \text {; NOAA: } 2 \text { (after } 1 \text { yr } \\
\text { serving can move to } 2 \text { days); SCC: } 2 \text {; Somas Mayfair: } 1 \text {; }\end{array}$ & $\begin{array}{l}\text { Theme 3, sub-theme 1: Nelson, Safirova } \\
\text { and Walls 2007; }\end{array}$ \\
\hline Pilot program? & SCC (ISD and Probation department); 511; & $\begin{array}{l}\text { Theme 3, sub-theme 1: Mokhtarian, Handy } \\
\text { and Salomon 1995; Nelson 2004; Nelson, } \\
\text { Safirova and Walls 2007; }\end{array}$ \\
\hline Unsupportive culture & SCC; & None \\
\hline $\begin{array}{l}\text { People requested } \\
\text { telecommuting option }\end{array}$ & SCC; Partners Mortgage & $\begin{array}{l}\text { Theme 1: Tayyaran and Khan 2007; Theme } \\
\text { 2: Brewer 1998; Moore, Staley and Poole Jr. } \\
\text { 2010; Bhatt, Peppard and Potts 2010; } \\
\text { Shaheen, Benjamin-Chung, Allen, and } \\
\text { Howe-Steiger 2009; }\end{array}$ \\
\hline Political acceptance issues & SCC; & None \\
\hline $\begin{array}{l}\text { Manager control } \\
\text { issues/negative } \\
\text { perceptions }\end{array}$ & SCC; Cisco; 511 (dispelled the myths); & None \\
\hline Facilities savings & $\begin{array}{l}\text { Cisco (selling off some of their buildings; typically no } \\
\text { more than } 50 \% \text { of employees in office at a time; buildings } \\
\text { empty on M and F); SCC; }\end{array}$ & None \\
\hline $\begin{array}{l}\text { Lower cube } \\
\text { heights/collaborative } \\
\text { workspaces }\end{array}$ & Cisco; & None \\
\hline Incentive & Cisco (brings in new employees); & $\begin{array}{l}\text { Theme 2: Lyons 2002; Bhatt, Peppard and } \\
\text { Potts 2010; Shaheen, Benjamin-Chung, } \\
\text { Allen, and Howe-Steiger 2009; Gardiner, } \\
\text { Lovaas and Horner 2011; Hartgen, Fields, } \\
\text { Scott and San Jose 2011; Theme 3, sub- } \\
\text { theme 1: Difiglio and Fulton 2000; Helling } \\
\text { and Mokhtarian 2001; }\end{array}$ \\
\hline Flexibility & $\begin{array}{l}\text { Cisco; 511; Somas Mayfair; City of San Jose; Partners } \\
\text { Mortgage }\end{array}$ & $\begin{array}{l}\text { Theme 1: Mannering and Mokhtarian 1995; } \\
\text { Theme 2: Moore, Staley and Poole Jr. 2010; }\end{array}$ \\
\hline
\end{tabular}




\begin{tabular}{|c|c|c|}
\hline & & $\begin{array}{l}\text { Hartgen, Fields, Scott and San Jose 2011; } \\
\text { Theme 3, sub-theme 1: Mokhtarian, Handy } \\
\text { and Salomon 1995; Theme 3, sub-theme 2: } \\
\text { Hjorthol 2002; }\end{array}$ \\
\hline Guilt & Cisco; & None \\
\hline $\begin{array}{l}\text { Changes in } \\
\text { communication }\end{array}$ & $\begin{array}{l}\text { Cisco (people use "ping" and email more than in- } \\
\text { person); Partners Mortgage }\end{array}$ & None \\
\hline $\begin{array}{l}\text { Sometimes in-office is } \\
\text { better }\end{array}$ & Cisco (negotiations facilitated by random walk-bys); & None \\
\hline Increased morale & Cisco; & None \\
\hline Eligibility issues & $\begin{array}{l}\text { Cisco; SCC (only CEMA covered employees); Los } \\
\text { Angeles (only LAPD); City of San Jose; } 511 \text { (appropriate } \\
\text { for employers and employee based on site location, } \\
\text { employee tasks, transit access, and eligibility); Somas } \\
\text { Mayfair; Partners Mortgage }\end{array}$ & Theme 2: Bhatt, Peppard and Potts 2010 \\
\hline Trip diaries & SCC (captures metrics); 511; & $\begin{array}{l}\text { Theme 3, sub-theme 1: Mokhtarian, Handy } \\
\text { and Salomon 1995; Theme 3, sub-theme 2: } \\
\text { Andrey, Burns and Doherty } 2004\end{array}$ \\
\hline Time-series analysis & SCC; 511; & None \\
\hline $\begin{array}{l}\text { Maintained or increased } \\
\text { productivity }\end{array}$ & SCC; 511; Cisco; Somas Mayfair; Partners Mortgage & $\begin{array}{l}\text { Theme 1: Marvin 1997; Theme 2: Brewer } \\
\text { 1998; }\end{array}$ \\
\hline Fewer sick days & 511; SCC; Somas Mayfair; Partners Mortgage & None \\
\hline $\begin{array}{l}\text { Allows for quiet } \\
\text { workspace }\end{array}$ & 511; Somas Mayfair; & None \\
\hline Establish rituals & 511; & None \\
\hline Home office furnishing & 511; & None \\
\hline Workers compensation & 511 & None \\
\hline GHG reductions & $\begin{array}{l}511 \text { (better than transit because of no engine cold starts or } \\
\text { running trains/buses); }\end{array}$ & $\begin{array}{l}\text { Theme 2: Hartgen, Fields, Scott and San } \\
\text { Jose 2011; Theme 3, sub-theme 1: } \\
\text { Mokhtarian, Handy and Salomon 1995; } \\
\text { Helling and Mokhtarian 2001; Theme 3, } \\
\text { sub-theme 2: Coroma, Hilty and Birtel } \\
\text { 2011; }\end{array}$ \\
\hline Reduces traffic congestion & 511; Somas Mayfair; & Theme 1: Rhee 2009; Marvin 1997; Theme \\
\hline
\end{tabular}




\begin{tabular}{|c|c|c|}
\hline Technology & $\begin{array}{l}511 \text { (will company provide work laptop?); Somas } \\
\text { Mayfair (limited infrastructure); Partners Mortgage }\end{array}$ & Theme 3, sub-theme 2: Hjorthol 2002; \\
\hline $\begin{array}{l}\text { Policy not available } \\
\text { publicly }\end{array}$ & Apple; Cisco Systems; Juniper Networks; & None \\
\hline Management support & $\begin{array}{l}\text { SCC (board of supervisors is very green minded: } \\
\text { installed solar panels; want to see telecommuting data to } \\
\text { see impact); }\end{array}$ & $\begin{array}{l}\text { Theme 2: Brewer 1998; Bhatt, Peppard and } \\
\text { Potts 2010; Hartgen, Fields, Scott and San } \\
\text { Jose 2011, 56; }\end{array}$ \\
\hline Lack of data & SCC; City of San Jose; & None \\
\hline TDM measure & City of San Jose; & Theme 2: Bhatt, Peppard and Potts 2010 \\
\hline Reducing waste goal & Somas Mayfair; & None \\
\hline Computer skills/literacy & Somas Mayfair; & None \\
\hline Training required & SCC; 511; & $\begin{array}{l}\text { Theme 2: Hartgen, Fields, Scott and San } \\
\text { Jose 2011, 56; }\end{array}$ \\
\hline Sprawl & 511 & $\begin{array}{l}\text { Theme 1: Rhee 2009; Tayyaran and Khan } \\
\text { 2007; Marvin 1997; Theme 2: Lyons 2002; }\end{array}$ \\
\hline Trust & Shenick & None \\
\hline $\begin{array}{l}\text { Travel time and time } \\
\text { savings }\end{array}$ & None specifically & $\begin{array}{l}\text { Theme 1: Tayyaran and Khan 2007; } \\
\text { Mannering and Mokhtarian 1995; Theme 2: } \\
\text { Brewer 1998; Theme 3, sub-theme 1: } \\
\text { Helling and Mokhtarian 2001; Theme 3, } \\
\text { sub-theme 2: Hamer, Kroes and Van } \\
\text { Ooststroom 1991; }\end{array}$ \\
\hline
\end{tabular}

2: Stopher 2004; Bhatt, Peppard and Potts 2010; Hartgen, Fields, Scott and San Jose 2011; Theme 3, sub-theme 1: Koenig, Henderson and Mokhtarian 1996; Nelson 2004; Helling and Mokhtarian 2001; Theme 3, sub-theme 2: Audirac 2002;

Theme 3, sub-theme 2: Hjorthol 2002;

None

publicly

Management support SCC (board of supervisors is very green minded: installed solar panels; want to see telecommuting data to see impact)

City of San Jose; Somas Mayfair;

Somas Mayfair Jose 2011, 56

None

Measure

Theme 2: Bhatt, Peppard and Potts 2010

Computer skills/literacy

Sprawl Jose 2011, 56

Theme 1: Rhee 2009; Tayyaran and Khan None 
This page intentionally left blank. 


\section{Appendix B: Synthesis of Telecommuting Policies}

Table 6: Telecommuting Policy Definitions

\begin{tabular}{|c|c|}
\hline Employer & Telecommuting Definition \\
\hline $\begin{array}{l}\text { Federal Government } \\
\text { (U.S. Congress. Senate. 2010. Telework } \\
\text { Enhancement Act of 2010. 111th } \\
\text { Cong., 2nd sess. S. Doc. 111-177.) }\end{array}$ & $\begin{array}{l}\text { "The term 'telework' refers to work arrangements under which employees perform } \\
\text { officially assigned duties at home or at other worksites convenient to home" (2). }\end{array}$ \\
\hline $\begin{array}{l}\text { State of California } \\
\text { (State of California. 2008. EXECUTIVE } \\
\text { ORDER S-04-08. } \\
\qquad \begin{array}{l}\text { http://gov.ca.gov/news.php?id=9629. } \\
\text { ) }\end{array}\end{array}$ & None \\
\hline $\begin{array}{l}\text { State of California } \\
\text { (California Department of General Services. } \\
\text { 2010. } 2010 \text { Telework Program Policy } \\
\text { and Procedures April. } \\
\frac{\text { http://www.documents.dgs.ca.gov/dg }}{\text { s/pio/telework/2010percent20Telewo }} \\
\frac{\text { rkpercent20Programpercent20Policy }}{\text { percent20andpercent20Procedurespe }} \\
\text { rcent20April.doc.) }\end{array}$ & $\begin{array}{l}\text { "Telecommuting: sending the work to the workers instead of sending the workers to } \\
\text { work; the partial or total substitution by telecommunications technology, possibly with } \\
\text { the aid of computers, for the commute to and from work" (1). }\end{array}$ \\
\hline $\begin{array}{l}\text { County of Santa Clara General Plan } \\
\text { (County of Santa Clara. 1994. Santa Clara } \\
\text { County General Plan. } \\
\text { http://www.sccgov.org/sites/plannin } \\
\text { g/PlansPrograms/GeneralPlan/Pages } \\
\text { /GP.aspx.) }\end{array}$ & "...the performance of work at home..." (F-6) \\
\hline $\begin{array}{l}\text { County of Santa Clara Climate Action } \\
\text { Plan } 2009 \\
\text { (Santa Clara County (SCC). 2009. Climate } \\
\text { action plan for operations and } \\
\text { facilities. } \\
\text { http://www.sccoov.org/SCC/docsper }\end{array}$ & $\mathrm{N} / \mathrm{A}$ \\
\hline
\end{tabular}




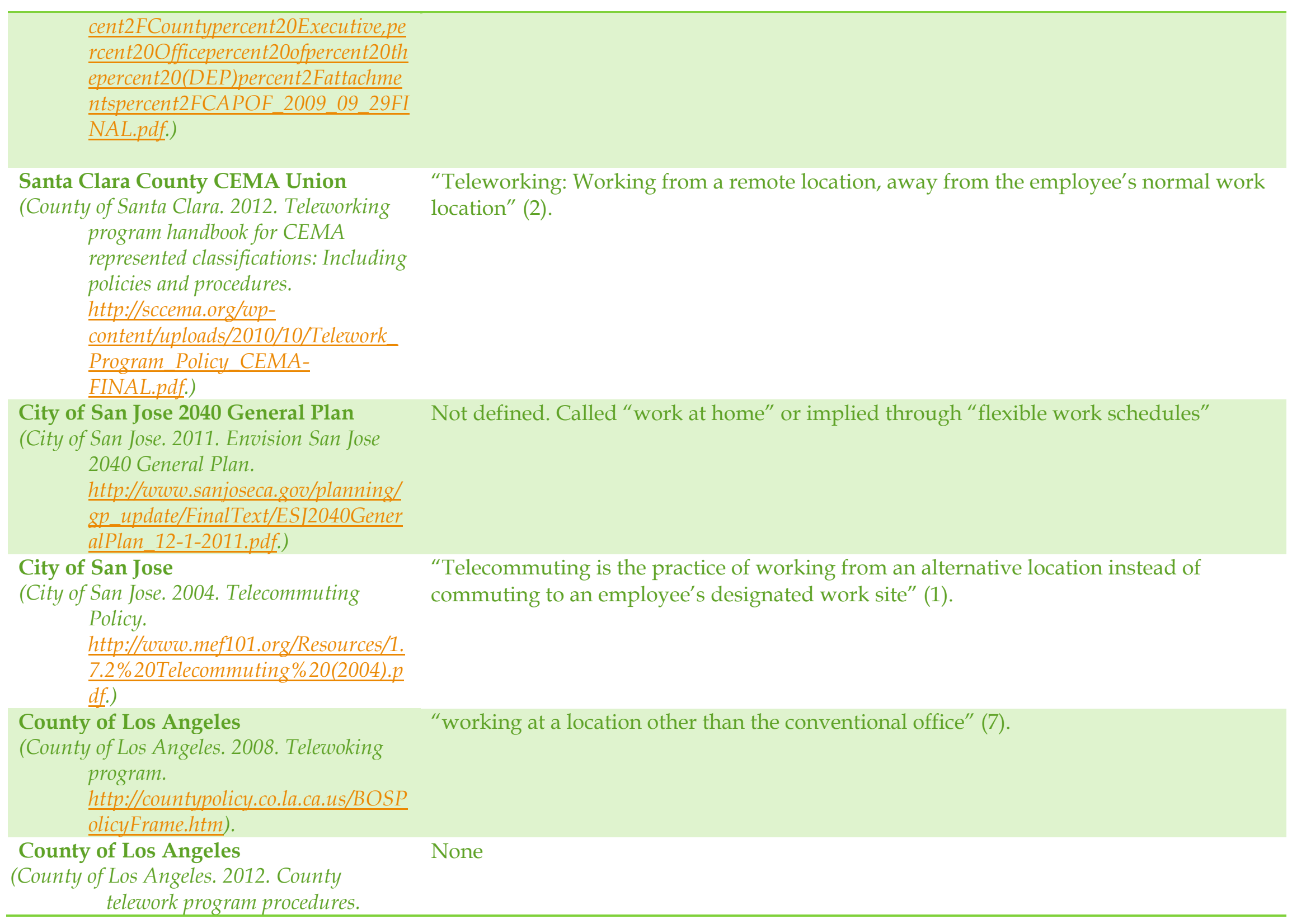




\begin{tabular}{|c|c|}
\hline $\begin{array}{l}\text { http://file.lacounty.gov/bos/supdoc } \\
\text { s/022212_Memo.pdf.) }\end{array}$ & \\
\hline $\begin{array}{l}\text { City of Los Angeles } \\
\text { (City of Los Angeles. 2008. Telemanager's } \\
\text { handbook. } \\
\text { http://per.lacity.org/bens/Telemana } \\
\text { gerHandbook.pdf.) }\end{array}$ & $\mathrm{N} / \mathrm{A}$ \\
\hline $\begin{array}{l}\text { City of Los Angeles } \\
\text { (Nilles, Jack M. 1993. City of Los Angeles } \\
\text { telecommuting project. Los } \\
\text { Angeles: JALA International, } \\
\text { Inc.) }\end{array}$ & $\mathrm{N} / \mathrm{A}$ \\
\hline $\begin{array}{l}\text { City of San Francisco } \\
\text { (City of San Francisco Department of } \\
\text { Human Resources. 2005. Pilot } \\
\text { telecommuting policy and program: } \\
\text { Program guidelines and } \\
\text { participation packet, by Philip A. } \\
\text { Ginsburg.) }\end{array}$ & $\begin{array}{l}\text { "an arrangement that allows eligible City employees an opportunity to perform their } \\
\text { work in a designated work area at home on specified work days" (8). }\end{array}$ \\
\hline $\begin{array}{l}\text { City of San Francisco } \\
\text { (City of San Francisco. 2011. Climate action } \\
\text { strategy for San Francisco's } \\
\text { transportation system. } \\
\quad \text { http://www.sfmta.com/cms/cmta/doc } \\
\qquad \begin{array}{l}\text { uments/4-19-11item13CAS- } \\
\text { citywide.pdf.) }\end{array}\end{array}$ & \\
\hline $\begin{array}{l}\text { City of San Francisco } \\
\text { (Newsom, Gavin. 2005. Executive directive } \\
\text { to implement telecommuting pilot } \\
\text { program. Memorandum.) }\end{array}$ & $\begin{array}{l}\text { "the opportunity to perform their work from designated areas at home during regular } \\
\text { work hours and days" (1). }\end{array}$ \\
\hline $\begin{array}{l}\text { City of San Francisco } \\
\text { (City and County of San Francisco. } 2001 . \\
\text { Work-life policies and practices } \\
\text { survey report. } \\
\text { http://s3.amazonaws.com/zanran_sto }\end{array}$ & "...the option of working "off-site, either at home or at a satellite office..." \\
\hline
\end{tabular}


rage/www.sfgov.org/ContentPages/7

\section{7.pdf.}

\section{City of Denver}

(Denver Regional Council of Governments. 2006. Denver telework toolkit.)

\section{Cisco Systems}

(Cisco Systems. Telecommuting policy (confidential)).

\section{Greenbelt Alliance}

Shenick Network Systems

Juniper Networks

Apple

Somas Mayfair

San Jose State University

(San Jose State University. 2009.

Telecommuting policy. http://www.sjsu.edu/hr/docs/risk/poli cies/telecommute pkg.pdf.)

\section{Partners Mortgage}

Valley Transportation Authority (VTA)

(Valley Transportation Authority. 2011. Congestion management program.)
"Teleworking, or telecommuting, is the concept of working from home or another location on a full- or part-time basis" (10).

“Telecommuting is any work performed outside of a Cisco office. This includes working from home or another location, working from an airport, airplane or hotel while traveling, or work at any non-Cisco location" (1).

N/A

$\mathrm{N} / \mathrm{A}$

$\mathrm{N} / \mathrm{A}$

$\mathrm{N} / \mathrm{A}$

$\mathrm{N} / \mathrm{A}$

“Telecommuting is defined as a specific work alternative program. This program provides the option of working at home or at University provided property, through written agreement and as approved by appropriate administrators" (1)

$\mathrm{N} / \mathrm{A}$

"A system of either working at home or at an off-site workstation with computer facilities that link to the worksite" (170).

Table 7: Telecommuting Eligibility

\begin{tabular}{llll}
\hline Government employer & Common & Different & Innovative \\
\hline Federal Government & $\begin{array}{l}\text { Agency or manager } \\
\text { determines eligibility }\end{array}$ & & \\
State of California & Not defined & \\
County of Santa Clara & No formal policy & & -Union member \\
Santa Clara County CEMA Union & -Permanent status & Union dependent & -Require training \\
& -Not on probation & -Training & prior to participation \\
\hline
\end{tabular}




\begin{tabular}{|c|c|c|c|}
\hline & $\begin{array}{l}\text {-Good last performance } \\
\text { review } \\
\text {-Appropriate job tasks } \\
\text {-Maintains or increases } \\
\text { productivity }\end{array}$ & & $\begin{array}{l}\text { (both manager and } \\
\text { employee) }\end{array}$ \\
\hline City of San Jose & $\begin{array}{l}\text {-Permanent employee } \\
\text { status for at least six } \\
\text { months } \\
\text {-Job performance review } \\
\text { "meets standards" or } \\
\text { higher } \\
\text {-20 percent of work week } \\
\text { spent at the office }\end{array}$ & & \\
\hline County of Los Angeles & $\begin{array}{l}\text {-Minimum in-person } \\
\text { contact } \\
\text {-Self-motivated } \\
\text {-Well-organized } \\
\text {-Works well } \\
\text { independently } \\
\text {-Good time management }\end{array}$ & Telecommuting training & $\begin{array}{l}\text { Require training } \\
\text { before participation }\end{array}$ \\
\hline City of Los Angeles & $\begin{array}{l}\text {-Minimum in-person } \\
\text { contact } \\
\text {-Self-motivated } \\
\text {-Well-organized } \\
\text {-Works well } \\
\text { independently } \\
\text {-Good time management }\end{array}$ & & \\
\hline City of San Francisco & $\begin{array}{l}\text {-Independent job in } \\
\text { nature } \\
\text {-Primarily "knowledge- } \\
\text { based" } \\
\text {-Project-oriented } \\
\text { activities } \\
\text {-Motivation }\end{array}$ & & \\
\hline
\end{tabular}




\begin{tabular}{|c|c|c|c|}
\hline & $\begin{array}{l}\text {-Productivity } \\
\text {-Time management skills } \\
\text {-Job rating of at least } \\
\text { "competent and } \\
\text { effective" } \\
\text {-Permanent status }\end{array}$ & & \\
\hline City of Denver & $\begin{array}{l}\text { Manager discretion } \\
\text {-Suitable job }\end{array}$ & & \\
\hline Private employer & Common & Different & Innovative \\
\hline Cisco & $\begin{array}{l}\text {-Manager discretion } \\
\text {-Suitable job }\end{array}$ & & \\
\hline San Jose State University & $\begin{array}{l}\text {-Regularly scheduled } \\
\text { employees }\end{array}$ & & \\
\hline Valley Transportation Authority (VTA) & & $\begin{array}{l}\text {-Most work is done on a } \\
\text { computer }\end{array}$ & \\
\hline
\end{tabular}

Table 8: Telecommuting Policy Benefits

\begin{tabular}{|c|c|c|c|}
\hline Government employer & Common & Different & Innovative \\
\hline Federal Government & $\begin{array}{l}\text {-Productive and satisfied } \\
\text { workers } \\
\text {-Environmental } \\
\text { considerations } \\
\text {-Reduced traffic } \\
\text { congestion } \\
\text {-Improved air quality } \\
\text {-Quality of life } \\
\text { considerations } \\
\text {-Work-life balance } \\
\text {-Office space savings }\end{array}$ & $\begin{array}{l}\text {-Continued government } \\
\text { operations during an } \\
\text { emergency } \\
\text {-"Hoteling" }\end{array}$ & $\begin{array}{l}\text {-Continued } \\
\text { government } \\
\text { operations during an } \\
\text { emergency (terrorist } \\
\text { attacks or natural } \\
\text { disasters) }\end{array}$ \\
\hline State of California & $\begin{array}{l}\text {-Reduce traffic } \\
\text { congestion } \\
\text {-Reduce global warming }\end{array}$ & $\begin{array}{l}\text {-Public safety } \\
\text {-Continued service services } \\
\text { during emergencies }\end{array}$ & $\begin{array}{l}\text {-Public safety } \\
\text {-Continued service } \\
\text { services during }\end{array}$ \\
\hline
\end{tabular}




\begin{tabular}{|c|c|c|c|}
\hline & $\begin{array}{l}\text { pollutants } \\
\text {-Improve air quality } \\
\text {-Reduce GHG emissions } \\
\text {-Increased employee } \\
\text { effectiveness } \\
\text {-Increased organization } \\
\text { effectiveness } \\
\text {-Office space savings } \\
\text {-Decreased energy } \\
\text { consumption } \\
\text {-Decreased air pollution } \\
\text {-Decreased traffic } \\
\text { congestion } \\
\text {-General work life } \\
\text {-Personal life } \\
\text {-Environmental } \\
\text { influences } \\
\text {-Creativity } \\
\text {-Stress avoidance } \\
\text {-Liberation } \\
\text {-Apprehension (includes } \\
\text { guilt about not working) } \\
\text {-Interdependence } \\
\text {-Aid for the mobility } \\
\text { impaired }\end{array}$ & $\begin{array}{l}\text {-Decreased sick leave } \\
\text {-Decreased medical costs } \\
\text {-Reduced parking } \\
\text { requirements } \\
\text {-Decreased turnover } \\
\text {-Decreased highway costs }\end{array}$ & $\begin{array}{l}\text { emergencies } \\
\text {-Decreased sick leave } \\
\text {-Decreased medical } \\
\text { costs } \\
\text {-Reduced parking } \\
\text { requirements } \\
\text {-Decreased turnover } \\
\text {-Decreased highway } \\
\text { costs }\end{array}$ \\
\hline County of Santa Clara & $\begin{array}{l}\text {-Reducing total amount } \\
\text { of travel } \\
\text {-Work tasks need to be } \\
\text { "location-independent" } \\
\text {-Helps reduce or mitigate } \\
\text { traffic congestion and } \\
\text { improve air quality }\end{array}$ & $\begin{array}{l}\text {-Employees were asking } \\
\text { for telecommuting as an } \\
\text { option } \\
\text {-Employees are healthier } \\
\text { and happier }\end{array}$ & $\begin{array}{l}\text {-Employees were } \\
\text { asking for } \\
\text { telecommuting as an } \\
\text { option }\end{array}$ \\
\hline Santa Clara County CEMA Union & $\begin{array}{l}\text {-CA State Assembly Bill } \\
\text { AB32: “encourages State }\end{array}$ & $\begin{array}{l}-“ \ldots \text { reduced commutes } \\
\text { can benefit the employee, }\end{array}$ & $\begin{array}{l}\text {-Written into the } \\
\text { CEMA union contract }\end{array}$ \\
\hline
\end{tabular}




\begin{tabular}{|c|c|c|c|}
\hline City of San Jose & $\begin{array}{l}\text {-Reduce GHGs and } \\
\text { VMTs } \\
\text {-"Employee who suffers } \\
\text { from a poor commute or } \\
\text { workplace stressors” (11) } \\
\text {-AB } 32 \text { (Global Warming } \\
\text { Solutions Act of 2006) } \\
\text { reducing GHG emissions } \\
\text { to } 1990 \text { levels by } 2020 \\
\text { (30). } \\
\text {-SB } 375 \text { "means of } \\
\text { achieving regional } \\
\text { transportation-related } \\
\text { GHG targets” (30). } \\
\text {-Sustainable } \\
\text { Communities Strategy } \\
\text { (SCS) made by MPOs to } \\
\text { reach regional targets } \\
\text { (30). } \\
\text {-MTC's regional } \\
\text { transportation plan called }\end{array}$ & $\begin{array}{l}\text {-A reward for reliability } \\
\text {-Retention incentive } \\
\text {-Americans with } \\
\text { Disabilities (ADA) Act of } \\
1990(29) \\
\text {-Citywide Emergency } \\
\text { Evacuation Plan (33). } \\
\text { COULD } \\
\text { TELECOMMUTING } \\
\text { SERVE AS A } \\
\text { COMPONENT OF AN } \\
\text { EMERGENCY COOP } \\
\text { PLAN? }\end{array}$ & $\begin{array}{l}\text {-A reward for } \\
\text { reliability } \\
\text {-Americans with } \\
\text { Disabilities (ADA) Act } \\
\text { of } 1990(29)\end{array}$ \\
\hline
\end{tabular}

and local governments to reduce greenhouse gas emissions" (2).

-"Reducing time employees spend on the road helps to reduce greenhouse gas emissions" (2).

-Emergency situations

(2).

-Fewer interruptions

-Not a replacement for

elder or child care

-Reduce GHGs and

-"Employee who suffers from a poor commute or orkplace stressors" (11) (Global Warming to 1990 levels by 2020 achieving regional -Sustainable

Communities Strategy (30)

transportation plan called the department and the

customers by making more efficient use of staff

time" (2).

.




\begin{tabular}{|c|c|c|c|}
\hline & $\begin{array}{l}\text { Transportation } 2035 \\
\text { which aims to "maintain, } \\
\text { manage, and improve the } \\
\text { surface transportation } \\
\text { system" (31). COULD } \\
\text { AN IMPROVEMENT BE } \\
\text { REMOVING CARS } \\
\text { FROM THE ROAD? }\end{array}$ & & \\
\hline County of Los Angeles & $\begin{array}{l}\text {-Increased productivity } \\
(5) \\
\text {-Improved employee } \\
\text { morale (5) } \\
\text {-Reduce absenteeism (5) } \\
\text {-Reduce employee's } \\
\text { carbon footprint (5) } \\
\text {-Regional clean air and } \\
\text { traffic goals (6) } \\
\text {-Reduces travel distance } \\
\text { by } 50 \text { percent (6) } \\
\text {-Work-life balance(6) } \\
\text {-Quality of life (6) } \\
\text {-Fewer interruptions (13) } \\
\text {-Less stress (13) } \\
\text {-Reduced travel expenses } \\
\text { (13) }\end{array}$ & $\begin{array}{l}\text {-"Maximize County } \\
\text { resources, reduce } \\
\text { absenteeism, increase } \\
\text { productivity and improve } \\
\text { employee morale" (6). } \\
\text {-ADA concerns; allows } \\
\text { employees with disabilities } \\
\text { to have equal access to jobs } \\
(23)\end{array}$ & \\
\hline City of Los Angeles & $\begin{array}{l}\text {-Air pollution reductions } \\
(2) \\
\text {-Cost effective (2) } \\
\text {-Reduced traffic } \\
\text { congestion (2) } \\
\text {-Reduced energy } \\
\text { dependency (2) } \\
\text {-Reduced office space } \\
\text { needs (2) }\end{array}$ & $\begin{array}{l}\text {-Reduce employee's carbon } \\
\text { footprint (5) } \\
\text {-Reduced energy } \\
\text { dependency (2) } \\
\text {-Reduced automobile cold } \\
\text { starts (48) }\end{array}$ & $\begin{array}{l}\text {-Reduce employee's } \\
\text { carbon footprint (5) } \\
\text {-ADA concerns; } \\
\text { allows employees } \\
\text { with disabilities to } \\
\text { have equal access to } \\
\text { jobs (23) } \\
\text {-Reduced energy } \\
\text { dependency (2) }\end{array}$ \\
\hline
\end{tabular}




\begin{tabular}{|c|c|c|c|}
\hline & $\begin{array}{l}\text {-Attracting and retaining } \\
\text { employees (3) }\end{array}$ & & $\begin{array}{l}\text {-Reduced automobile } \\
\text { cold starts (48) }\end{array}$ \\
\hline City of San Francisco & $\begin{array}{l}\text {-reduce environmental } \\
\text { impacts (5) } \\
\text {-economic efficiencies (5) } \\
\text { - function during an } \\
\text { emergency } \\
\text {-Reduce vehicle miles } \\
\text { traveled } \\
\text {-Reduce energy } \\
\text { consumption } \\
\text {-Reduce air pollution } \\
\text {-Reduce traffic and } \\
\text { parking congestion } \\
\text {-Increased productivity } \\
\text {-Continued recruitment } \\
\text { and retention } \\
\text {-Flexibility } \\
\text {-Work-life balance } \\
\text {-Morale and job } \\
\text { satisfaction; } \\
\text {-Reduce absenteeism } \\
\text {-Reduce commute time } \\
\text { and costs }\end{array}$ & $\begin{array}{l}\text {-Effective use of staff and } \\
\text { resources }\end{array}$ & \\
\hline City of Denver & $\begin{array}{l}\text {-Weather issues } \\
\text {-Sick employees }\end{array}$ & & \\
\hline Private employer & Common & Different & Innovative \\
\hline Cisco & $\begin{array}{l}\text {-Productivity } \\
\text {-Work-life balance } \\
\text {-Effective work } \\
\text { environment }\end{array}$ & $\begin{array}{l}\text {-Mutually beneficial for } \\
\text { employee and manager }\end{array}$ & $\begin{array}{l}\text {-Mutually beneficial } \\
\text { for employee and } \\
\text { manager }\end{array}$ \\
\hline San Jose State University & $\begin{array}{l}\text {-Cost savings } \\
\text {-Commute reductions }\end{array}$ & $\begin{array}{l}\text {-Operational performance } \\
\text { improvements }\end{array}$ & $\begin{array}{l}\text {-Operational } \\
\text { performance }\end{array}$ \\
\hline
\end{tabular}




\begin{tabular}{|c|c|c|c|}
\hline Valley Transportation Authority (VTA) & -Avoid congestion (59). & $\begin{array}{l}\text { "...significantly reduce a } \\
\text { company's overall peak- } \\
\text { period trips" (79) }\end{array}$ & $\begin{array}{l}\text { during emergencies } \\
\text { "...significantly } \\
\text { reduce a company's } \\
\text { overall peak-period } \\
\text { trips" (79) }\end{array}$ \\
\hline
\end{tabular}

Table 9: Telecommuting Policy Issues

\begin{tabular}{|c|c|c|}
\hline Government employer & Common & Different \\
\hline Federal Government & $\begin{array}{l}\text {-Many managers start out resistant (6) } \\
\text {-Need strong formal policies and procedures in } \\
\text { place }(6) \\
\text { "-Need to education managers and employees in } \\
\text { order to increase participation (6) } \\
\text {-Employee performance must not decrease (8) } \\
\text {-Employees job must be eligible with limited face- } \\
\text { to-face interactions needed ( } 8)\end{array}$ & \\
\hline State of California & $\begin{array}{l}\text {-Management training (10) } \\
\text {-Need uniform telecommuting guidelines (10) }\end{array}$ & \\
\hline County of Santa Clara & NONE & NONE \\
\hline $\begin{array}{l}\text { Santa Clara County } \\
\text { CEMA Union }\end{array}$ & -Manager discretion & \\
\hline City of San Jose & & - Generation X wanting work-life balance (11) \\
\hline County of Los Angeles & $\begin{array}{l}\text {-Not meant to be child or elderly care substitute } \\
\text { (14) }\end{array}$ & \\
\hline City of Los Angeles & $\begin{array}{l}\text {-Not meant to be child or elderly care substitute } \\
\text { (8) }\end{array}$ & $\begin{array}{l}\text {-Zoning ordinances (6) } \\
\text {-Way employees are managed is changing with } \\
\text { more mobile and global work. Mangers must } \\
\text { grow with the changes (5) } \\
\text {-Meeting objectives more important measure of } \\
\text { effectiveness (5) }\end{array}$ \\
\hline
\end{tabular}




\begin{tabular}{|c|c|c|}
\hline & & $\begin{array}{l}\text {-Must clearly define objectives and duties (5) } \\
\text {-Need good communication (5) }\end{array}$ \\
\hline City of San Francisco & -Management issues & $\begin{array}{l}\text {-Legal issues } \\
\text {-Information security } \\
\text {-Employee accountability } \\
\text {-Policies and programs too "labor-intensive" to } \\
\text { create and use }\end{array}$ \\
\hline City of Denver & -Not meant to be child or elderly care substitute & -Workers' compensation issues \\
\hline Private employer & Common & Different \\
\hline Cisco & NONE & NONE \\
\hline San Jose State University & -Not meant to be child or elderly care substitute & \\
\hline $\begin{array}{l}\text { Valley Transportation } \\
\text { Authority (VTA) }\end{array}$ & NONE & NONE \\
\hline
\end{tabular}




\section{Appendix C: Synthesis of Other Relevant Telecommuting Research}

Table 10: Non-Policy Telecommuting Definition and Eligibility Criteria

\begin{tabular}{|c|c|c|c|}
\hline Employer & $\begin{array}{l}\text { Research } \\
\text { Title }\end{array}$ & Telecommuting Definition & $\begin{array}{l}\text { Eligibili } \\
\text { ty } \\
\text { Criteria }\end{array}$ \\
\hline $\begin{array}{l}\text { City of Denver } \\
\text { (Convey, Eric. 2010. Denver ranks } 4^{\text {th }} \text { in telecommute study. Denver Business } \\
\quad \text { Journal. } . \text { ttp://wwww.bizjournals.com/denver/stories/2010/03/08/daily33.html } \\
\quad \text { (accessed December 10, 2012)) }\end{array}$ & $\begin{array}{l}\text { Denver } \\
\text { Business } \\
\text { Journal } \\
\text { article }\end{array}$ & None & None \\
\hline $\begin{array}{l}\text { Denver company: Alpine Access } \\
\text { (Alpine Access. Telework Case Study. } \\
\text { http://www3.drcog.org/ridearrangers/content/documents/Casepercent20Studi } \\
\text { espercent20Alpinepercent20Access.pdf.) }\end{array}$ & $\begin{array}{l}\text { Not } \\
\text { listed; } \\
\text { this is a } \\
\text { call } \\
\text { center } \\
\text { business }\end{array}$ & None & None \\
\hline $\begin{array}{l}\text { Denver company: Rocky Mountain Center for Health Promotion and } \\
\text { Education } \\
\text { (Ride Arrangers Denver Regional Council of Governments (2). Telework case study: } \\
\text { Rocky Mountain Center for Health Promotion and Education. } \\
\text { http://www3.drcog.org/waytogo/content/documents/Casepercent20Studiesper } \\
\quad \text { cent20Rockypercent20Mountainpercent20Center.pdf (accessed December 10, } \\
\text { 2012)) }\end{array}$ & Not listed & None & None \\
\hline $\begin{array}{l}\text { Denver company: SKLD Information Services } \\
\text { (Ride Arrangers Denver Regional Council of Governments (3). Telework case study: } \\
\text { SKLD Information Services. } \\
\quad \text { http://www3.drcog.org/waytogo/content/documents/Casepercent20Studiesper } \\
\quad \text { cent20SKLD.pdf (accessed December 10, 2012)) }\end{array}$ & Not listed & None & None \\
\hline $\begin{array}{l}36 \text { Commuting Solutions (website) } \\
\text { (36 Commuting Solutions. 2012. Telework: A modern luxury. } 36 \text { Commuting } \\
\text { Solutions. http://36commutingsolutions.org/commuting-us-36/commute- } \\
\text { options/telework/) }\end{array}$ & $\begin{array}{l}\text { Provide } \\
\text { help for } \\
\text { people or } \\
\text { companie } \\
\text { S who } \\
\text { want to }\end{array}$ & None & None \\
\hline
\end{tabular}




\begin{tabular}{|c|c|c|}
\hline & $\begin{array}{l}\text { telecomm } \\
\text { ute }\end{array}$ & \\
\hline $\begin{array}{l}\text { IBM: Working Outside the Box Paper } \\
\text { (Caldow, Janet. 2009. Working outside the box: A study on the growing momentum } \\
\quad \text { in telework. Institute for Electronic Government, IBM Corporation.) }\end{array}$ & $\begin{array}{l}\text { GOOD } \\
\text { QUOTE } \\
\text { FROM } \\
\text { OBAMA } \\
\text { pg } 11\end{array}$ & $\begin{array}{l}\text { "...paper, we define } \\
\text { teleworkers as those } \\
\text { employees who, by the } \\
\text { nature of their jobs, can work } \\
\text { anywhere and are fully } \\
\text { capable } \\
\text { of performing all job duties } \\
\text { and interactions with their } \\
\text { employers outside a } \\
\text { traditional office" (4). }\end{array}$ \\
\hline $\begin{array}{l}\text { Yahoo: All Things D.com report "Physically Together": Here's the Internal } \\
\text { Yahoo No-Work-From-Home Memo for Remote Workers and Maybe More" } \\
\text { by Kara Swisher (2/22/2013) }\end{array}$ & $\begin{array}{l}\text { Ban on } \\
\text { telecomm } \\
\text { uting as } \\
\text { of June } \\
2013\end{array}$ & $\begin{array}{l}\frac{\text { http://allthingsd.com/20130 }}{222 / \text { physically-together- }} \text { No one } \\
\text { heres-the-internal-yahoo-no- } \\
\text { work-from-home-memo- } \\
\text { which-extends-beyond- } \\
\text { remote-workers/ }\end{array}$ \\
\hline \multicolumn{3}{|l|}{$\begin{array}{l}\text { Deloitte: report "Federal Telework and Workplace Flexibility Solutions: } \\
\text { Moving from compliance to competitiveness" (September 2012) } \\
\text { (Deloitte Development, LLC. 2012. Federal telework and workplace flexibility } \\
\quad \text { solutions: Moving from compliance to competiveness.) }\end{array}$} \\
\hline $\begin{array}{l}\text { Deloitte report: "Telework in the Federal Government" } 2010 \\
\text { (Deloitte Development, LLC. 2012. Federal telework and workplace flexibility } \\
\text { solutions: Moving from compliance to competiveness.) }\end{array}$ & & $\begin{array}{l}\text { "Telework is an alternative } \\
\text { work arrangement for } \\
\text { employees. It allows } \\
\text { employees to conduct some } \\
\text { or all of their work at an } \\
\text { alternative worksite away } \\
\text { from the employer's } \\
\text { traditional office" (3). }\end{array}$ \\
\hline $\begin{array}{l}\text { Cisco } \\
\text { Cisco Systems. 2011. Managed Teleworker Service. (confindential). }\end{array}$ & $\begin{array}{l}\text { “Manage } \\
\text { d } \\
\text { Telework }\end{array}$ & \\
\hline
\end{tabular}




\begin{tabular}{|c|c|c|c|}
\hline & $\begin{array}{l}\text { er } \\
\text { Service" } \\
\text { powerpoi } \\
\text { nt } 2011\end{array}$ & & \\
\hline $\begin{array}{l}\text { Cisco } \\
\text { Cisco Systems. 2011. Flexible Work Practices Overview. (confidential). }\end{array}$ & $\begin{array}{l}\text { Flexible } \\
\text { Work } \\
\text { Practices } \\
\text { Overview } \\
2011\end{array}$ & $\begin{array}{l}\text { A guiding principle behind } \\
\text { promoting telecommuting is } \\
\text { building manager-employee } \\
\text { trust. The way we work is } \\
\text { changing and a cultural shift } \\
\text { has started. Work is not } \\
\text { where you are, but what you } \\
\text { do. (9). }\end{array}$ & $\begin{array}{l}\text { - } \\
\text { "Eligibil } \\
\text { ity } \\
\text { based } \\
\text { on } \\
\text { perform } \\
\text { ance } \\
\text { track } \\
\text { record } \\
\text { and } \\
\text { readines } \\
\text { s" (9). } \\
\text { - } \\
\text { manage } \\
\text { ment } \\
\text { approva } \\
\text { l and } \\
\text { job } \\
\text { suitabili } \\
\text { ty } \\
\text { require } \\
\text { d (9). }\end{array}$ \\
\hline
\end{tabular}

Table 11: Non-Policy Benefits

\begin{tabular}{ll}
\hline Employer & Benefits \\
\hline City of Denver & -"Denver is the No. 4 U.S. medium- or large-sized city for telecommuting." \\
& -more productive \\
& -work-life balance \\
\hline
\end{tabular}




\begin{tabular}{|c|c|}
\hline & $\begin{array}{l}\text {-gas savings } \\
\text {-avoid long commute }\end{array}$ \\
\hline Denver company: Alpine Access & $\begin{array}{l}\text {-"ability to hire quality people } \\
\text {-responsiveness, and } \\
\text {-financial benefits for the company" }\end{array}$ \\
\hline $\begin{array}{l}\text { Denver company: Rocky Mountain } \\
\text { Center for Health Promotion and } \\
\text { Education }\end{array}$ & $\begin{array}{l}\text { "-save about } 120 \text { minutes per teleworking day by not commuting } \\
\text {-use this saved time to do more work, spend more time with their families and exercise. } \\
\text {-On an annual basis, reduce their vehicle miles traveled by } 28,000 \text { miles and prevent about } \\
1,630 \text { lbs. of air pollution." (2) } \\
\text {-improved morale } \\
\text {-greater job retention }\end{array}$ \\
\hline $\begin{array}{l}\text { Denver company: SKLD Information } \\
\text { Services }\end{array}$ & $\begin{array}{l}\text { "Employer Benefits: } \\
\text {-Reduced employee turnover - 0percent voluntary turnover } \\
\text {-Up to 87percent reduction in unscheduled absences } \\
\text {-Reduced Worker's Comp claims } \\
\text {-Lower overhead through reduced occupancy cost } \\
\text { Employee Benefits: } \\
\text {-Better morale } \\
\text {-Flexible scheduling } \\
\text {-No need to outsource, jobs remained in the U.S. } \\
\text { Community Benefits: } \\
-190,000 \text { commute-miles saved annually } \\
-11,320 \text { pounds of pollution prevented" (1). }\end{array}$ \\
\hline 36 Commuting Solutions (website) & $\begin{array}{l}\text {-Increased employee productivity } \\
\text {-Improved employee recruitment and retention } \\
\text {-Improved employee morale } \\
\text {-Reduced overhead costs } \\
\text {-Decreased demands for office and parking space } \\
\text { Employees who telework benefit from: } \\
\text {-Less parking and commuting expenses } \\
\text {-Better balance of work and personal lives } \\
\text {-Reduced stress }\end{array}$ \\
\hline IBM: Working Outside the Box & -reduce costs $(5)$ \\
\hline
\end{tabular}


-reduce facilities and real estate costs (5)

-saved 5 million gallons of gas during 2007 through mobility program (5)

-prevented emission of more than 450,000 tons of CO2 emissions in 2007 through mobility program (5).

-Meet climate change mandates (6)

-helps with national security and disaster planning, including extreme weather conditions (6)

-attracting and retaining employees, including top talent (6)

-reducing traffic congestion (6)

-reducing commuting time and costs (6)

-increased work-life balance (6)

"Benefits of Telework

- Employer cost savings in real estate, energy consumption, capital assets, training

- Employee cost savings in commuting expense

- Continuity of operations during disasters

- Attraction and retention of talent

- Reduced traffic congestion

- Lower C02 emissions

- Highly productive and efficient employees focused on results

- Greater employee job satisfaction

- Improved work/life balance

- Maximized use of geographically-dispersed

employee resources

- Workplace innovation

- Access to skills on a team perhaps not otherwise available" (7).

QUOTE: "Geography is no longer an obstacle to employers or employees." (7).

-"Today, 40percent of IBM's some 386,000 employees in 173 countries have no office at all” (9).

-“Between 1990 and 2005, IBM avoided more than 8.98 million metric tons of CO2 emissions through the mobile work program by conserving a cumulative 17.2 billion $\mathrm{kWh}$ of electricity. Total savings from energy management in 2005 was \$22.9 million. In 2007 in the US alone, the work-at-home program conserved more than 5 million gallons of fuel and avoided more than 450,000 tons of CO2 emissions. Savings in real estate costs and CO2 emissions far outweigh the cost to transition an employee to mobile status. Once the 
Yahoo: All Things D.com report "Physically Together": Here's the Internal Yahoo No-Work-FromHome Memo for Remote Workers and Maybe More" by Kara Swisher $(2 / 22 / 2013)$

Deloitte: report "Federal Telework and Workplace Flexibility Solutions: Moving from compliance to competitiveness" (September 2012)

infrastructure is in place, marginal costs decrease" (9).

QUOTE: "II believe that it's

time we stopped talking about family values and start pursuing policies that truly value families, such as paid family leave, flexible work schedules, and telework, with the federal government leading by example." ("Obama Wrote Federal Staffers About His Goals," Carol D. Leonnig, The Washington Post, November 11, 2008) (11).

-"Dispel conventional wisdom to reassure managers and employees: Teleworkers report the same or higher job satisfaction as those who work in an office in terms of informal interactions with coworkers, sense of belonging, communications with managers, and career development. And, studies find teleworkers tend to work longer hours with fewer interruptions and are more productive than their office peers" (11).

Deloitte report: "Telework in the Federal Government" 2010
-“ Deloitte has successfully implemented workplace flexibility in our own organization resulting in cost savings of approximately

$\$ 30$ million in capital expenditures in the first year and increased employee satisfaction. We apply this experience to support our

clients in improving organizational performance through an integrated approach to workplace flexibility" (4).

- "[Workplace flexibility] is an issue that affects the wellbeing of our families and the success of our businesses. It affects the strength of our economy - whether we'll create the workplaces and jobs of the future we need to compete in today's global economy."

- President Barack Obama, White House Forum on Workplace Flexibility (March 2010) (8). -productivity

-morale/stress

-retention/recruiting (key retention tool for working parents, reduces stress from commuting, and allows wider sourcing of key talent)

-work-life integration

-cost benefits 


\begin{tabular}{|c|c|}
\hline & $\begin{array}{l}\text {-real estate (cost reductions and hoteling) } \\
\text {-greening } \\
\text {-traffic congestion } \\
\text {-infrastructure spending } \\
\text {-preparedness } \\
\text {-continuity of operations (H1N1 influenza and terrorists attacks) } \\
\text {-air pollution (less congestion, reduced emissions, fuel economy, and energy conservation) } \\
\text { ALL from page } 4\end{array}$ \\
\hline Cisco & $\begin{array}{l}\text {-Top reasons for allowing employees to telecommuting: reducing enterprise costs and } \\
\text { improve "enterprise workforce effectiveness" (8). } \\
\text {-Top technologies to allow enable telecommuting: Cloud computing, networking, Voice and } \\
\text { data communications, and mobile technologies" (8). } \\
\text { "Enabling Business Continuity and Minimizing Cost:" } \\
\text {-“Enable employees when they can't reach the office" (9). } \\
\text {-“Retain talent and improve their quality of life" (9). } \\
\text {-“Meet new government regulations" (9). } \\
\text {-“Stay green: reduce commuter emissions" (9). } \\
\text {-“Expand recruiting efforts to employ top talent" (9). } \\
\text {-“Maintain or increase employee productivity" (9). } \\
\text {-“Lower facility and operational costs" (9). } \\
\text {-“Provide anytime access to sales and customer support" (9). } \\
\text {-In a Cisco case study, they found telecommuting was able to improve productivity by } \\
\text { roughly } 30 \text { percent per work week, reduced commute hours by almost } 3 \text { hours per work } \\
\text { week, and increased telecommuting days to almost } 3.5 \text { days per week (10). Their greenhouse } \\
\text { gas reductions we a little over } 30 \text { percent, company real estate savings } \$ 277 \text { million dollars a } \\
\text { year, and employee commute saving } \$ 43 \text { million a year (10). }\end{array}$ \\
\hline Cisco & $\begin{array}{l}\text {-the way people work is changing and telecommuting is a way to change with the times (5). } \\
\text { Changes like telecommuting help Cisco reach their green goals (5). }\end{array}$ \\
\hline
\end{tabular}

Table 12: Non-Policy Barriers/Issues

\begin{tabular}{ll}
\hline Employer & Issues \\
\hline City of Denver & -lack of face-to-face interaction \\
\hline
\end{tabular}




\begin{tabular}{|c|c|}
\hline Denver company: Alpine Access & None \\
\hline $\begin{array}{l}\text { Denver company: Rocky Mountain } \\
\text { Center for Health Promotion and } \\
\text { Education }\end{array}$ & None \\
\hline $\begin{array}{l}\text { Denver company: SKLD Information } \\
\text { Services }\end{array}$ & None \\
\hline 36 Commuting Solutions (website) & None \\
\hline IBM: Working Outside the Box Paper & $\begin{array}{l}\text {-“The Texas Transportation Institute estimates traffic congestion costs the United States } \$ 78 \\
\text { billion each year for the } 4.2 \text { billion hours people are stuck in traffic and more } 2.9 \text { billion } \\
\text { gallons of wasted fuel" (6). } \\
\text {-“So, overall, why is progress so difficult? Like Alice in Wonderland's Cheshire cat said, "If } \\
\text { you don't know where you're going, it's difficult to get there.” Restructuring requires an } \\
\text { understanding of the } \\
\text { changing nature of work, a business strategy with measurable goals, coordination across } \\
\text { human resources, real estate management, finance, and information technology } \\
\text { departments, and employees equipped to do their jobs without an office” (11). } \\
\text { - }\end{array}$ \\
\hline $\begin{array}{l}\text { Yahoo: All Things D.com report } \\
\text { "Physically Together": Here's the } \\
\text { Internal Yahoo No-Work-From-Home } \\
\text { Memo for Remote Workers and } \\
\text { Maybe More" by Kara Swisher } \\
\text { (2/22/2013) }\end{array}$ & $\begin{array}{l}\text { "To become the absolute best place to work, communication and collaboration will be } \\
\text { important, so we need to be working side-by-side. That is why it is critical that we are all } \\
\text { present in our offices. Some of the best decisions and insights come from hallway and } \\
\text { cafeteria discussions, meeting new people, and impromptu team meetings. Speed and } \\
\text { quality are often sacrificed when we work from home." }\end{array}$ \\
\hline \multicolumn{2}{|l|}{$\begin{array}{l}\text { Deloitte: report "Federal Telework } \\
\text { and Workplace Flexibility Solutions: } \\
\text { Moving from compliance to } \\
\text { competitiveness" (September 2012) }\end{array}$} \\
\hline \multicolumn{2}{|l|}{$\begin{array}{l}\text { Deloitte report: "Telework in the } \\
\text { Federal Government" } 2010\end{array}$} \\
\hline Cisco & -security risks, productivity, large up-front investments as issues to deal with (44). \\
\hline Cisco & \\
\hline
\end{tabular}

